\title{
SARS-CoV-2 Portrayed against HIV: Contrary Viral Strategies in Similar Disguise
}

\author{
Ralf Duerr *, Keaton M. Crosse, Ana M. Valero-Jimenez and Meike Dittmann
}

Citation: Duerr, R.; Crosse, K.M.; Valero-Jimenez, A.M.; Dittmann, M. SARS-CoV-2 Portrayed against HIV: Contrary Viral Strategies in Similar Disguise. Microorganisms 2021, 9, 1389. https://doi.org/10.3390/ microorganisms 9071389

Academic Editors: Ruth Serra-Moreno and Andrés Finzi

Received: 6 April 2021

Accepted: 7 June 2021

Published: 27 June 2021

Publisher's Note: MDPI stays neutral with regard to jurisdictional claims in published maps and institutional affiliations.

Copyright: (c) 2021 by the authors. Licensee MDPI, Basel, Switzerland. This article is an open access article distributed under the terms and conditions of the Creative Commons Attribution (CC BY) license (https:/ / creativecommons.org/licenses/by/ $4.0 /)$.
Department of Microbiology, New York University School of Medicine, New York, NY 10016, USA; Keaton.Crosse@nyulangone.org (K.M.C.); AnaMayela.ValeroJimenez@nyulangone.org (A.M.V.-J.); Meike.Dittmann@nyulangone.org (M.D.)

* Correspondence: Ralf.Duerr@nyulangone.org

\begin{abstract}
SARS-CoV-2 and HIV are zoonotic viruses that rapidly reached pandemic scale, causing global losses and fear. The COVID-19 and AIDS pandemics ignited massive efforts worldwide to develop antiviral strategies and characterize viral architectures, biological and immunological properties, and clinical outcomes. Although both viruses have a comparable appearance as enveloped viruses with positive-stranded RNA and envelope spikes mediating cellular entry, the entry process, downstream biological and immunological pathways, clinical outcomes, and disease courses are strikingly different. This review provides a systemic comparison of both viruses' structural and functional characteristics, delineating their distinct strategies for efficient spread.
\end{abstract}

Keywords: SARS-CoV-2; HIV; zoonotic viruses; COVID-19 and AIDS pandemics; viral entry

\section{Introduction}

SARS-CoV-2 and HIV each rapidly became and continue to be considerable global health concerns. Unparalleled scientific efforts enabled characterization of these viruses and their resulting diseases in record time, which has led to rapid development of public health measures and antiviral strategies. Both viruses have elementary similarities, being enveloped viruses with a positive (+) single-stranded (ss) RNA genome. Consequently, preventive and therapeutic approaches that were studied or established for HIV have been tested against SARS-CoV-2 including vaccination strategies, reverse vaccinology, monoclonal antibodies (mAbs), and investigational or approved anti-HIV drugs [1-3]. While more data keep unfolding, we know that despite overall similarities, both viruses have key differences spanning structural and functional characteristics, cellular tropism, induced immune responses, clinical outcome, and responsiveness to vaccines and treatments (Table 1). For SARS-CoV-2, emergency use authorizations of vaccines have been achieved to prevent severe coronavirus disease COVID-19; however, treatment options remain scarce. For HIV, more than 45 antiretroviral drugs are available to manage chronic disease and delay AIDS; however, we still lack an efficient vaccine. This review illustrates the fundamental similarities and differences of SARS-CoV-2 and HIV to further our understanding of their biological and clinical characteristics and thus support the development of antiviral strategies against current and future viral outbreaks. Since HIV-1 is responsible for $>95 \%$ of global HIV infections and HIV-2 has remained largely restricted to Western Africa [4], this review focuses on HIV-1. 
Table 1. Comparison of key features between SARS-CoV-2 and HIV-1 and their associated diseases.

\begin{tabular}{|c|c|c|c|}
\hline & HIV-1 & SARS-CoV-2 & Refs \\
\hline \multicolumn{4}{|c|}{ Demographic features } \\
\hline geographic origin & $\begin{array}{c}\text { West-Central Africa (Cameroon, DR } \\
\text { Congo) }\end{array}$ & China (Wuhan) & {$[5,6]$} \\
\hline first recorded case & $\begin{array}{l}\text { HIV-1: } 1959 \text { (DR Congo) } \\
\text { AIDS: } 1981 \text { (USA) }\end{array}$ & $\begin{array}{l}\text { SARS-CoV-2: Nov. 17, } 2019 \text { (China) } \\
\text { COVID-19: Dec. 31, } 2019 \text { (China) }\end{array}$ & {$[7-10]$} \\
\hline $\begin{array}{l}\text { est. time of origin/cross-species } \\
\text { transmission }\end{array}$ & $1920 \mathrm{~s}$ & October/November 2019 & {$[7,11-13]$} \\
\hline animal source & non-human primates & $\begin{array}{l}\text { primary host: bats, intermediate } \\
\text { hosts: small mammals; yet } \\
\text { unconfirmed }\end{array}$ & {$[5,14-16]$} \\
\hline active cases & $38 \mathrm{Mio}^{\mathrm{a}}$ & $12 \mathrm{Mio}^{\mathrm{b}}$ & {$[17,18]$} \\
\hline cases since pandemic start & $\begin{array}{c}76 \mathrm{Mio}^{\text {a }} \text { (1.7 Mio new infections in } \\
\text { 2019) }\end{array}$ & 179 Mio $^{b}$ & {$[17,18]$} \\
\hline deaths since pandemic start & $33 \mathrm{Mio}^{\text {a }}$ (0.7 Mio in 2019) & 3.9 $\mathrm{Mio}^{\mathrm{b}}$ & [17-19] \\
\hline \multicolumn{4}{|c|}{ Viral features } \\
\hline Baltimore virus classification & Group VI & Group IV & \multirow{2}{*}[20,21]{} \\
\hline virus family & Retroviridae & Coronaviridae & \\
\hline virus diameter & $100-150 \mathrm{~nm}$ & $60-140 \mathrm{~nm}$ & {$[6,22,23]$} \\
\hline number of spikes per virus & $7-14$ & $15-40$ & [23-25] \\
\hline spike size (height $\times$ width) & $12 \times 15 \mathrm{~nm}$ & $20 \times 13 \mathrm{~nm}$ & [26-29] \\
\hline spike amino acids & 856 & 1273 & {$[30,31]$} \\
\hline $\begin{array}{l}\text { potential N-glyco sites per spike } \\
\text { monomer }\end{array}$ & 31 (HxB2) & 22 (Wuhan-Hu-1) & {$[30,31]$} \\
\hline spike proteolytic cleavage sites & 1 & 2 & {$[32,33]$} \\
\hline capsid & $\begin{array}{c}\text { Conical (many hexagons and } 12 \\
\text { pentagons of subunits) }\end{array}$ & helical & [34-36] \\
\hline genome & $\begin{array}{c}\text { (+)ssRNA, diploid } \\
\text { dsDNA genome intermediate }\end{array}$ & (+)ssRNA, haploid & {$[37,38]$} \\
\hline genome size & $\begin{array}{l}9.7 \mathrm{~kb} \text { (one of the smallest viral } \\
\text { genomes) }\end{array}$ & $\begin{array}{c}29.7 \mathrm{~kb} \text { (one of the largest viral } \\
\text { genomes) }\end{array}$ & {$[30,31]$} \\
\hline evolution rate & $\begin{array}{c}\text { proviral DNA: } 4 \times 10^{-3} \text { per base per } \\
\text { cell }(1 \text { mutation every } 250 \text { base pairs }) \\
\text { virus in plasma: } 2-17 \times 10^{-3} \text { per base } \\
\text { per year }\end{array}$ & $\begin{array}{c}1 \times 10^{-3} \text { per base per year }(2 \\
\text { mutations per month) }\end{array}$ & {$[12,39,40]$} \\
\hline $\begin{array}{l}\text { within-host diversity (in the } \\
\text { absence of superinfection) }\end{array}$ & $<5 \%$ ( $<10 \%$ for proviral env) & $<0.05 \%$ & [41-43] \\
\hline replication cycle & $\sim 24 \mathrm{~h}$ (in vitro)-60 h (in vivo) & $\sim 7-36 \mathrm{~h}$ & [44-48] \\
\hline \multicolumn{4}{|c|}{ Entry and host responses } \\
\hline primary target cells & $\mathrm{CD}^{+}{ }^{+} \mathrm{T}$ cells, Macrophages & $\begin{array}{l}\text { ACE2+ mucosal and endothelial } \\
\text { cells }\end{array}$ & {$[49,50]$} \\
\hline primary entry receptors/proteins & CD4, CCR5/CXCR4 & ACE2, TMPRSS2 & [51-53] \\
\hline
\end{tabular}


Table 1. Cont.

\begin{tabular}{|c|c|c|c|}
\hline & HIV-1 & SARS-CoV-2 & Refs \\
\hline \multirow{3}{*}{ antibody response } & $\begin{array}{c}\text { Ab binding and neutralization response } \\
\text { develops in first month } \\
\mathrm{nAb} \text { development associated with } \\
\text { viremia and severity }\end{array}$ & $\begin{array}{l}\text { Ab binding and neutralization } \\
\text { response develops in } 1-2 \text { weeks } \\
\mathrm{nAb} \text { development associated with } \\
\text { viremia and severity }\end{array}$ & \multirow{3}{*}{ [54-57] } \\
\hline & $\begin{array}{c}\text { bnAb development usually requires } \\
2-3 \text { years of productive infection } \\
\text { (observed in } \sim 10 \% \text { of HIV-1-infected } \\
\text { individuals) }\end{array}$ & $\begin{array}{l}\text { nAbs develop within weeks of } \\
\text { infection }\end{array}$ & \\
\hline & $\begin{array}{l}\text { bnAbs require high rates of somatic } \\
\text { hypermutation }\end{array}$ & $\begin{array}{l}\text { Potent nAbs do not require high } \\
\text { rates of somatic hypermutation } \\
\text { (SHM), but SHM fosters breadth, } \\
\text { potency, and resilience to viral } \\
\text { escape }\end{array}$ & \\
\hline cellular response & $\begin{array}{l}\text { impaired B cell, } \mathrm{T} \text { cell and } \\
\text { macrophage/monocyte responses }\end{array}$ & $\begin{array}{c}\text { impaired B cell, } \mathrm{T} \text { cell and } \\
\text { macrophage/monocyte responses }\end{array}$ & [58-63] \\
\hline cytokine response & $\begin{array}{l}\text { delayed and enhanced } \\
\text { anti-inflammatory response, impaired } \\
\text { IFN response in progressive cases }\end{array}$ & $\begin{array}{c}\text { delayed and enhanced } \\
\text { anti-inflammatory response, } \\
\text { impaired IFN response in severe } \\
\text { cases }\end{array}$ & [64-70] \\
\hline
\end{tabular}

\begin{tabular}{|c|c|c|c|}
\hline & Disease features, treatment, and & accines & \\
\hline \multirow{3}{*}{ clinical symptoms } & AIDS & COVID-19 & \multirow{8}{*}[6,49,71-77]{} \\
\hline & $\begin{array}{l}\text { (1) initially mild, common cold-like } \\
\text { symptoms }\end{array}$ & $\begin{array}{c}\text { (1) respiratory infection (fever, } \\
\text { cough, sore throat, fatigue, loss of } \\
\text { smell) }\end{array}$ & \\
\hline & $\begin{array}{l}\text { (2) acquired immune deficiency and } \\
\text { opportunistic infections and } \\
\text { malignancies }\end{array}$ & $\begin{array}{l}\text { (2) systemic dissemination } \\
\text { throughout the body (blood vessels, } \\
\text { nervous system, inner organs) }\end{array}$ & \\
\hline type of infection & $\begin{array}{c}\text { chronic (HIV-1 integrates as provirus } \\
\text { into host genome) }\end{array}$ & acute & \\
\hline \multirow[b]{2}{*}{ duration of infection } & \multirow[b]{2}{*}{ life-long } & 1-2 months (mild) & \\
\hline & & $\begin{array}{l}\text { 2-9 months (severe) and possible } \\
\text { chronic complications }\end{array}$ & \\
\hline primary site of infection & $\begin{array}{l}\text { lymphatic system of gut and } \\
\text { reproductive system }\end{array}$ & respiratory system & \\
\hline primary mode of infection & sexual transmission & droplet infection of airways & \\
\hline treatment & $\begin{array}{l}>45 \text { FDA-approved drugs, strong } \\
\text { viral-suppressive effect but no cure } \\
\text { drugs mainly target the polymerase } \\
\text { region (reverse transcriptase, protease, } \\
\text { and integrase) }\end{array}$ & $\begin{array}{c}\text { (emergency use) authorization of a } \\
\text { few drugs, limited clinical benefit } \\
\text { (dexamethasone, remdesivir, nAb } \\
\text { cocktails) }\end{array}$ & {$[70,78-80]$} \\
\hline \multirow[t]{2}{*}{ vaccine } & no vaccine & $\begin{array}{c}\text { (emergency use) authorization of a } \\
\text { few vaccines, up to } 95 \% \text { vaccine } \\
\text { efficacy }\end{array}$ & \multirow[t]{2}{*}{ [81-85] } \\
\hline & $\begin{array}{c}7 \text { vaccine efficacy trials completed, best } \\
\text { efficacy: } 31 \% \text { (RV144, 2009) }\end{array}$ & $\begin{array}{l}>200 \text { vaccine trials ongoing or } \\
\text { completed }\end{array}$ & \\
\hline correlates of protection & $\begin{array}{c}\text { animal models: neutralizing antibodies; } \\
\text { human vaccine trial (RV144): ADCC, } \\
\text { low plasma anti-Env IgA/IgG, } \\
\text { poly-functional B cell responses, } \\
\text { non-neutralizing V2 antibodies }\end{array}$ & $\begin{array}{l}\text { neutralizing antibodies, supported } \\
\text { by cellular responses }\end{array}$ & {$[81,86,87]$} \\
\hline
\end{tabular}




\section{Methods}

Structural analyses were performed using UCSF Chimera v.1.15rc [88] based on pdb files downloaded from the Research Collaboratory for Structural Bioinformatics Protein Data Bank (RCSB PDB). Protein structures were generated using pdb files 3j5m or 6wpu (prefusion "closed" HIV-1 Env), S.pdb [89] (prefusion "closed" SARS-CoV-2 spike trimer), 411a (HIV-1 protease in complex with lopinavir), 6wnp (SARS-CoV-2 main protease in complex with Boceprevir), 3v4i/3v81 (HIV-1 reverse transcriptase [RT] in complex with DNA, azathioprine-triphosphate [3v4i; red], and nevirapine [3v81; purple], the latter superimposed after structural overlay of 3v4i and 3v81 RT structures), and 7bv2 (SARSCoV-2 polymerase RdRp [NSP12] in complex with NSP7, NSP8, template-primer RNA, and Remdesivir triphosphate). Complex entry models were created using structural overlays using MatchMaker in Chimera of pdb structures 6vyb, 6m17, and S_ACE2 [89] (SARSCoV-2), or 6met and 5vn3 (HIV-1). Models of fusion intermediates were created based on pdb files $6 \mathrm{~m} 3 \mathrm{w}$ (SARS-CoV-2) and 2zfc (HIV-1). In silico glycosylation of proteins was performed using GlyProt [90], and the composition of oligomannose, hybrid, and complex N-glycans matched with reference literature [91,92]. Viral life cycle schematics were created with BioRender including trimer structures of prefusion "closed" HIV-1 Env (pdb 3j5m) and SARS-CoV-2 spike (pdb 6vxx) as well as activated, "partially open" HIV-1 Env (pdb 5vn3) and SARS-CoV-2 spike (pdb 6vyb). Viral sequences were downloaded from the Global initiative on sharing all influenza data (GISAID)-EpiCoV and the Los Alamos National Laboratory (LANL) HIV Databases [30,93]. For better comparability, phylogenetics and genetic diversity analyses were performed using HIV-1 and SARS-CoV-2 sequences from one entire year, respectively. For SARS-CoV-2, the first year of the pandemic was studied (mid-December 2019-mid-December 2020), and all full-length sequences with high coverage were downloaded for the studied countries. For HIV-1, we selected a year (January-December) in which a comparable number of HIV-1 unique sequences had been deposited (within $1.5 \mathrm{log}$ difference) relative to the SARS-CoV-2 data set in the same country. Duplicate HIV-1 sequences were removed using the ElimDupes tool from the LANL database. Multiple sequence alignments were performed using Mafft on XSEDE v.7.402 as implemented in the CIPRES Science Gateway v. 3.1 [94]. RAxML maximum likelihood trees were generated using RAxML-HPC v.8 on XSEDE with 1000 bootstrap replicates on CIPRES. Phylogenetic trees were visualized using FigTree v.1.4.3 [95]. Highlighter plots were created using ten study sequences covering all major branches of the phylogenetic trees against SARS-CoV-2 or HIV-1 reference sequences Wuhan_Hu_1 (EPI ISL 402125) or HxB2 (K03455), respectively. Genetic distances were calculated using the ape package ("K80" model without pairwise deletion of sites with missing data) and displayed as heatmaps (upper triangle of all pairwise genetic distances) using the complex heatmap package in program R v.4.0.2 x64 and RStudio v.1.3.959 [96,97]. The longitudinal course of clinical and laboratory parameters was modeled based on available data the time of the manuscript's completion (June 2021) as summarized and cited in the review's respective sections.

\section{Origins of SARS-CoV-2 and HIV-1}

HIV-1 and likely SARS-CoV-2 as well, originated from zoonosis as they are both understood to have originally been transmitted to humans from non-human animals. The World Health Organization (WHO) defines zoonosis as a disease or infection that is naturally transmissible from vertebrate animals to humans [98]. HIV is the result of multiple cross-species transmissions of simian immunodeficiency viruses (SIVs) naturally infecting African primates such as African green monkeys, sooty mangabeys, mandrills, chimpanzees, and others [5]. SIVs are largely non-pathogenic in their natural hosts, while HIV-1 causes the acquired immunodeficiency syndrome (AIDS) in humans. There are two major types of human immunodeficiency virus (HIV), type 1 (HIV-1) and type 2 (HIV-2), differing genetically by nearly 55\% [99]. HIV-2 origins were confirmed by demonstrating that humans in West Africa harbored HIV-2 strains that resembled a locally circulating 
SIV in sooty mangabeys (Cercocebus atys) [100]. This virus has remained largely restricted to West Africa since its discovery in 1989 [101]. On the other hand, HIV-1 disseminated within the human population exhibiting high genetic heterogeneity and giving rise to four distinct groups based on multiple cross-species transmission events: $\mathrm{M}$ (major), $\mathrm{O}$ (outlier), N (non-M/non-O) and P [102-106]. Group M viruses are responsible for the HIV-1 global pandemic, further classified in distinct subtypes (A-D, F-H, and J-L), sub-subtypes (A1-A6, F1, and F2), and circulating and unique recombinant forms [107]. HIV-1 originated from the transmission of a closely related SIV strain from chimpanzees (Pan troglodytes) to humans that was first found in 1989 in two captive chimpanzees in Gabon and isolated from one of them. Sera from these animals cross-reacted with all HIV-1 proteins including envelope proteins [101]. The last common ancestor of HIV-1 group M has been dated to approximately 1910 to 1930, indicating that HIV-1 first emerged in West-Central Africa and spread for some 50 to 70 years before it was recognized [101]. Although the early transmission, dissemination, and establishment of the ape precursors of HIV-1 groups M, N, $\mathrm{O}$, and $\mathrm{P}$ in human populations remain unclear, it is believed that transmission of SIV into humans occurred through cutaneous or mucous membrane exposure to infected ape blood and/or body fluids exposures common in the context of bush meat hunting, a longstanding common component of household economies throughout Sub-Saharan Africa [11,101,108]. A rapid worldwide spread of HIV-1 has been favored by its enormous genetic variability and rapid evolution, making the virus highly adaptable to new hosts [99].

Since HIV-1, the major driver of the HIV pandemic, originated from great apes such as chimpanzee and gorilla, the initial reservoir and the pathology is mostly restricted to/specific for hominids. In contrast, the reservoir of betacoronaviruses such as severe acute respiratory syndrome coronavirus 1 and 2 (SARS-CoV-1 and SARS-CoV-2) and Middle East respiratory syndrome coronavirus (MERS-CoV) is substantially broader and includes bats, cats, dogs, pangolins, minks, ferrets, and even camelids in the case of MERSCoV [109-112]. Compared to HIV, coronavirus cross-species transmission events between humans and animals are believed to occur more frequently and back and forth, leading to potentially more diffuse epidemic dynamics that might be harder to control.

SARS-CoV-2 is estimated to have originated between October and December 2019 from zoonosis, but the exact origin remains under extensive scrutiny [113]. The confirmation of a viral pathogen's zoonotic origin often relies on the isolation of a virus from a non-human animal that shares $>99 \%$ whole-genome nucleotide identity. In the case of SARS-CoV-2, there has yet to be the isolation of such a $>99 \%$ similar virus from a non-human animal. The most closely related virus, RaTG13, was isolated in 2013 from a horseshoe bat (Rhinolophus affinis) within the Yunnan province, China, and shares $96 \%$ nucleotide identity [114]. While the presence of this sequence in wild bat populations strongly suggests that SARS-CoV-2 originated in bats, the sequence divergence of these two viruses represents approximately 20 years of evolution, suggesting that RaTG13 can only be regarded as an evolutionary precursor and not a direct progenitor [115]. Moreover, RaTG13 is considerably divergent from SARS-CoV-2 within the receptor-binding domain (RBD) of the spike protein, resulting in an approximately 1,000-fold lower affinity of RaTG13 spike to the human ACE2 receptor than SARS-CoV-2 spike [116]. These findings suggest that there is an intermediate host linking the transmission of SARS-CoV-2 from bats to humans.

The pangolin has been implicated as an intermediate host of SARS-CoV-2 due to the isolation of a coronavirus-denoted Pangolin-CoV (or GD/1/2019) from a sick Malayan pangolin [117]. Pangolin-CoV is identical to SARS-CoV-2 in all five critical residues for receptor binding of the RBD but has only $92 \%$ whole-genome nucleotide identity [117]. Analysis of horizontal gene transfer and recombination lends support for intragenic recombination of the spike genes between RaTG13 and Pangolin-CoV, which could have given rise to the chimeric SARS-CoV-2 [118]. However, neither RaTG13 nor Pangolin-CoV contain the polybasic furin cleavage site at the S1/S2 junction, which is present within the spike protein of SARS-CoV-2 and greatly contributes to the virus's tropism and pathogenicity [119]. Moreover, additional analysis conversely suggests that the presence of identical functional 
sites within the RBD of SARS-CoV-2 and Pangolin-CoV likely arose independently through random mutations and strong natural selection in addition to recombination, refuting the intermediate transmission of pangolins [120]. Overall, the origin of SARS-CoV-2 remains elusive and in order to clearly identify the natural non-human reservoir of SARS-CoV-2 and confirm its zoonosis, extensive sampling of potential host species is necessary. However, this is likely to be a challenging endeavor as SARS-related coronaviruses are known to be widely distributed across Asia [121]. Additionally, the now widespread distribution of SARS-CoV-2 in humans may result in spillover events to non-human animals, which may undermine any surveillance sampling programs.

\section{Operating Principles of SARS-CoV-2 and HIV-1}

The difference between SARS-CoV-2 and HIV-1extends over their genome organization, repertoire/functioning of viral proteins (see Section 4.1), and viral life cycle (see Section 4.2). The latter includes differences in viral entry, specifically their cellular and receptor tropism (see Section 4.2.1), translation and transcription programs, which, in the case of HIV-1, involve RNA reverse transcription and integration of HIV-1 proviral DNA into the host genome (see Section 4.2.3). Both viruses benefit from their customized annexation of the cellular machinery (see Section 4.2.3) and have peculiarities in the proteolytic processing of viral proteins (see Section 4.2.4).

\subsection{Viral Composition}

Both SARS-CoV-2 and HIV-1 are enveloped viruses with a (+)ssRNA genome and a critical set of structural and functional proteins complemented by a broad spectrum of viral co-factors (Figure 1). Despite a $\sim 3$-fold difference in genome size, SARS-CoV-2 and HIV-1 virions are similarly sized ( $\sim 100 \mathrm{~nm}$ in diameter). According to the Baltimore virus classification, SARS-CoV-2 belongs to group IV viruses, characterized by (+)ssRNA, whereas HIV-1 is listed among group VI viruses, i.e., ssRNA-RT viruses with (+)sense RNA and a DNA intermediate in the life cycle [20,21]. More specifically, SARS-CoV-2 belongs to the family of Coronaviridae (realm: Riboviria, order Nidovirales, genus: Betacoronaviruses, subgenus: Sarbecoviruses, species: Severe acute respiratory syndrome-related coronaviruses), which are the largest known RNA viruses with genomes approximately $30 \mathrm{~kb}$ in size (Figure 1, Table 1) [122]. Coronaviruses are named after their crown-like appearance in electron microscopic pictures evoked by their large spike glycoproteins extending from the roughly spherical virions. HIV-1 belongs to the family of Retroviridae (realm: Riboviria, order: Ortervirales, genus: Lentiviruses) [123]. Two copies of HIV-1 RNA are enclosed by a characteristic conical capsid of $\sim 2,000$ copies of the viral Gag protein (p24). The capsid is surrounded by a mantle of viral matrix proteins (p17) and a lipid bilayer derived from the infected host cell. The latter is spiked with trimeric viral envelope proteins (Env), the sole viral protein on the HIV-1 surface and the mediator of cellular entry. We refer to this protein also as spike to align it with SARS-CoV-2 nomenclature. While the SARS-CoV-2 spike number is moderate compared to other enveloped viruses such as influenza, it is even lower for HIV-1, with 14 or fewer Env spikes incorporated into the viral membrane (Figure 1, Table 1) [124]. The high plasticity of HIV-1 and SARS-CoV-2, as characteristic for Retroviridae and Coronaviridae, and their potential to tolerate sequence and structural changes without critical loss of function has warranted their zoonotic transmission and ongoing evolutionary success [125,126]. 
(a)

HIV-1

(b) HIV-1
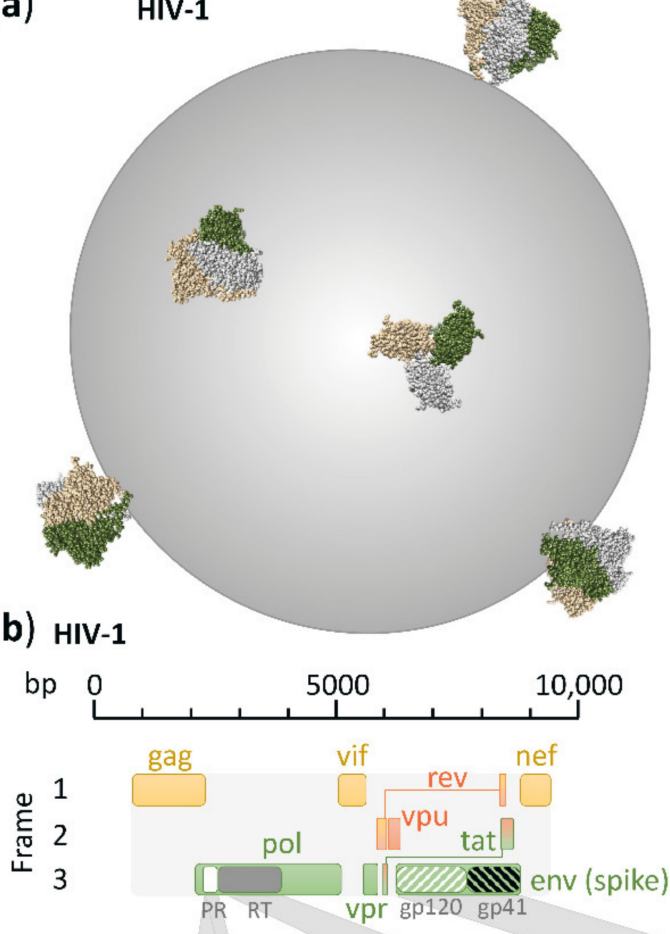
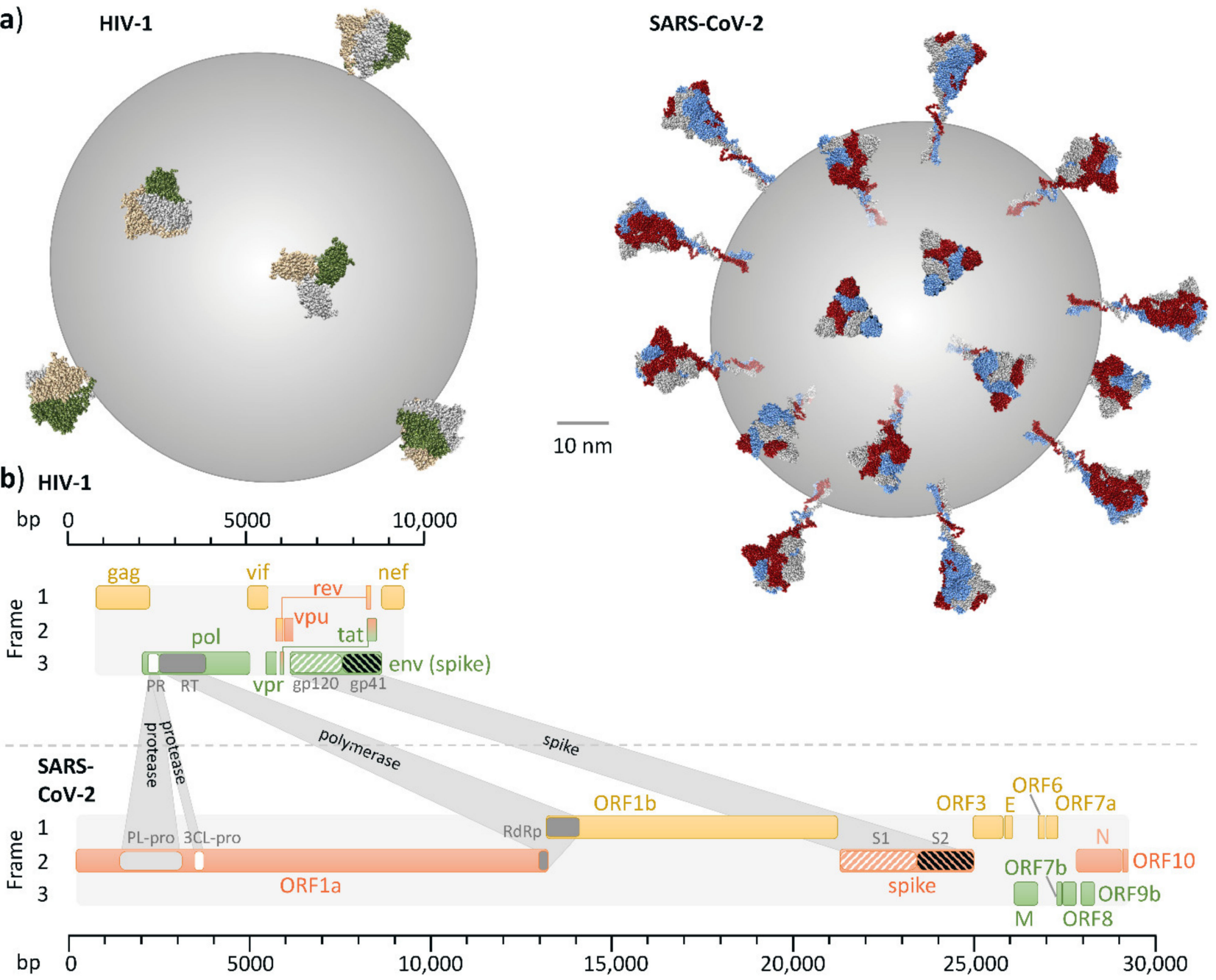

(c)

protease

polymerase

Spike (prefusion)

backbone
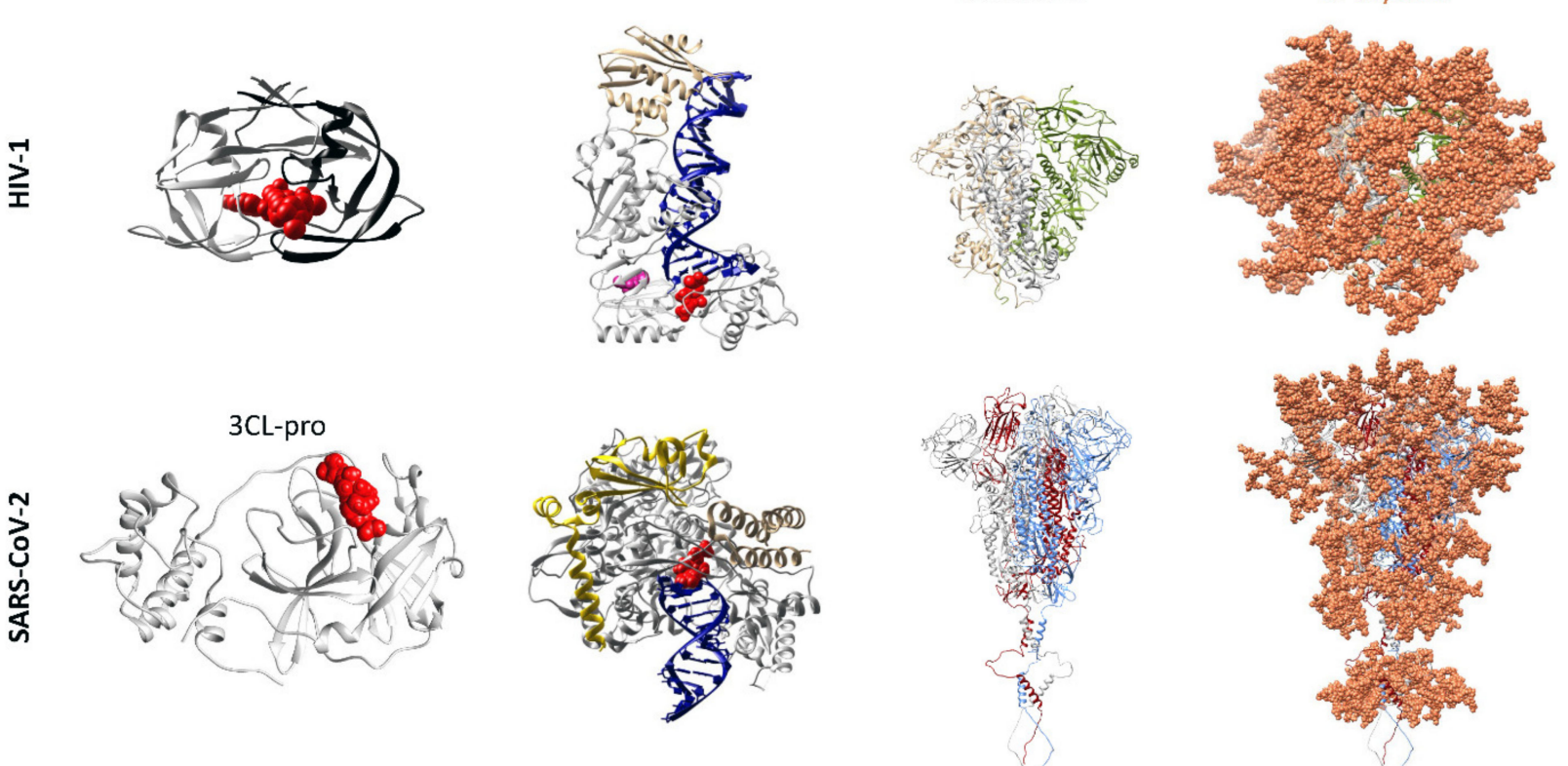

Figure 1. Comparison of HIV-1 and SARS-CoV-2 key viral features. (a) HIV-1 and SARS-CoV-2 are enveloped viruses with a diameter of $\sim 100 \mathrm{~nm}$. They are decorated with trimeric spike proteins that mediate viral entry, yet SARS-CoV-2 spikes 
appear in higher numbers than HIV-1 Env (see Table 1). (b) HIV-1 and SARS-CoV-2 possess differently sized, positivestranded RNA genomes. The HIV-1 genome is $\sim 10 \mathrm{~kb}$ in size, whereas the SARS-CoV-2 genome spans almost $30 \mathrm{~kb}$. Genomic regions coding for the key functional or structural proteins protease, polymerase, and spike are highlighted in white, gray, and black and white stripes. (c) Three structural and functional proteins highlighted in (b) are also shown as 3D structures (ribbon representation), with bound inhibitors shown in red or purple (sphere representation). Protein subunits are colored differentially. Polymerase-bound RNA/DNA is shown in blue. HIV-1 and SARS-CoV-2 spike proteins are shown as amino acid backbone structures (left) and glycoproteins (right) with modeled N-glycans (coral; sphere representation).

The HIV-1 genome codes for nine viral genes (gag, pol, env, vif, vpr, vpu, tat, rev, and nef) encoding 18 proteins (the Gag proteins MA, CA, SP1, NC, SP2, and P6, the Pol proteins RT, RNase H, IN, and PR, the Env proteins gp120 and gp41, the regulatory proteins Tat and Rev, and the accessory proteins Nef, Vpr, Vif, and Vpu). In addition to the structurally and functionally necessary gag, pol, and env genes, the regulatory and accessory tat, rev, nef, vif, vpr, and vpu modulate HIV-1 infection, replication, viral release, and immune recognition [127]. The SARS-CoV-2 genome codes for 14 open-reading frames (ORFs) encoding 29 proteins [128]. The $5^{\prime}$-end of the genome is dominated by the large ORF1a and ORF1b genes, comprising more than $2 / 3$ of the entire $\sim 30 \mathrm{~kb}$ genome. They encode polyproteins, which, upon translation, are proteolytically processed into 16 non-structural proteins (NSP1-NSP16) that mostly belong to the replicase-transcriptase complex. At the $3^{\prime}$-end of the genome, 13 ORFs are expressed from subgenomic RNAs: in addition to nine accessory proteins, SARS-CoV-2 encodes four structural proteins, as typical for coronaviruses, i.e., spike, envelope (E), matrix (M), and nucleocapsid (N), the latter complexing the RNA genome in the absence of a surrounding capsid as is the case for HIV-1. In contrast to HIV-1, all the three remaining structural SARS-CoV-2 proteins are incorporated into the viral membrane (spike, E, and M), with spike mediating viral entry. In addition to the canonical ORFs, numerous discontinuous transcription events make the SARS-CoV-2 transcriptome highly complex, including transcripts encoding unknown ORFs with fusions, deletions, and/or frameshifts [129].

SARS-CoV-2 and HIV-1 encode spike glycoproteins, comprised of mainly oligomannose N-glycans in HIV-1 and more balanced complex, oligomannose, and hybrid N-glycans in SARS-CoV-2 [91,92,130]. The higher number of N-glycans on a smaller spike protein renders the HIV-1 glycan shield denser than that of SARS-CoV-2, complicating Ab access to critical entry epitopes with consequences for the development of efficient vaccines (Figure 1, Table 1).

\subsection{Viral Replication}

Although HIV-1 and SARS-CoV-2 are both enveloped viruses with a (+)ssRNA genome, they have evolved different strategies to enter their host cells, replicate, and release their progeny (Figure 2). Despite engaging different entry receptors and target cells, HIV-1 and SARS-CoV-2 follow similar principles of class I glycoprotein-mediated viral fusion and entry (see Section 4.2.1). However, transcription and downstream processes are critically different (see Section 4.2.2). Maybe the most fundamental difference is that the SARS-CoV-2 life cycle occurs entirely in the cytoplasm, whereas the HIV-1 life cycle partially occurs in the nucleus. For this reason, HIV-1 replication takes approximately double the time of SARS-CoV-2 replication. Specifically, HIV-1 reverse transcription was shown to initiate at approximately $3 \mathrm{~h}$ post infection (h.p.i.), with double-stranded viral cDNA being detectable $2 \mathrm{~h}$ later [44]. In $\mathrm{CD}^{+} \mathrm{T}$ cell lines, integration starts 8.5 h.p.i. and all viral transcripts are detectable $\sim 15$ h.p.i. The viral gene expression peak is reached between 20 and 23 h.p.i., with $\sim 0.6 \%$ of all transcripts in the cell demanded by the virus. The release of viral particles stretches over several hours and is initiated at 18 h.p.i. and can continue to 36 h.p.i. in vitro or 60 h.p.i. in vivo (Figure 2a) [44,45]. In contrast, a SARS-CoV-2 replication cycle takes only $~ 12 \mathrm{~h}$ in A549 cell and in human airway epithelial cell cultures (HAEC), and time-of-addition experiments showed that initial translation and viral replication start simultaneously at between 2 and 3 h.p.i. (Figure 2b) [48]. The 
following chapter presents the life cycles of both viruses, with a focus on contrasting these two life cycles.
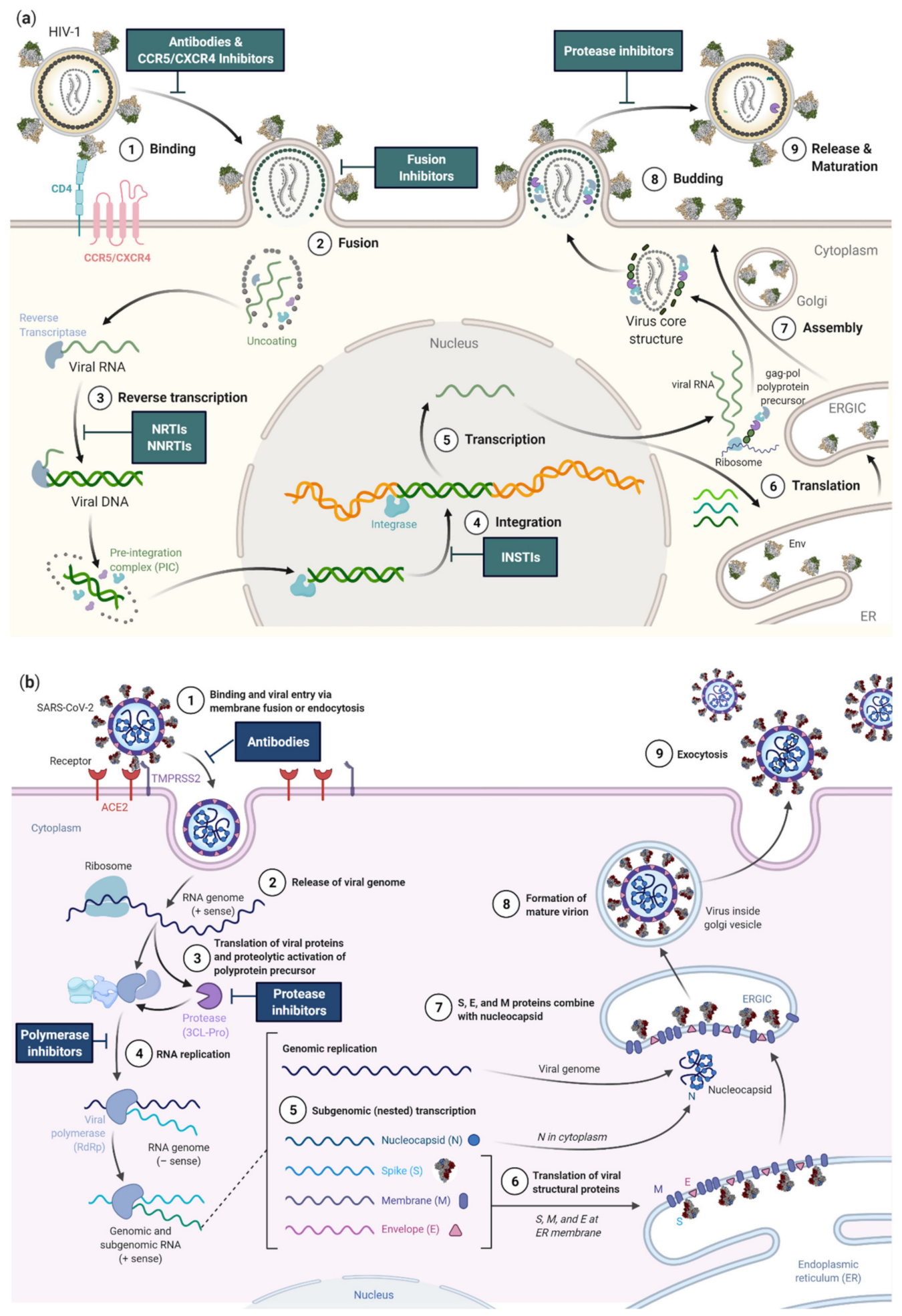

Figure 2. Replication cycles of (a) HIV-1 and (b) SARS-CoV-2 and major sites of therapeutic intervention. 3CL-pro: 3C-like protease; ACE2: angiotensin-converting enzyme 2; ER: endoplasmic reticulum; ERGIC: endoplasmic-reticulum-Golgi intermediate compartment; INSTI: integrase strand transfer inhibitor; NRTI: nucleoside analog reverse transcriptase inhibitor; NNRTI: non-NRTI; TMPRSS2: Transmembrane protease serine 2. 


\subsubsection{Viral Entry}

As the first step of the viral replication cycle, cellular entry is one of the most critical, as it decides the fate of both the virus and the cell. For this reason, the viral glycoproteins and cellular receptors that facilitate this process are central targets for vaccines, antibody therapies, and small molecular drugs (Figure 2). For enveloped viruses, including HIV-1 and SARS-CoV-2, entry begins with an attachment step to cellular receptors, followed by conformational changes of their receptor-binding glycoproteins, and is completed with the fusion of viral and host membranes.

Attachment of SARS-CoV-2 and HIV-1 is facilitated by the glycoproteins incorporated within their viral envelope membranes. The glycoproteins of both SARS-CoV-2 and HIV-1 are trimeric class I fusion proteins, named spike or Env (also known as gp160), respectively. Both are composed of an N-terminal attachment domain (S1; gp120) mediating receptor binding and a C-terminal fusion domain (S2; gp41) consisting of four critical elements enabling viral fusion, i.e., fusion peptide (FP), heptad repeat 1 and 2 (HR1, HR2), and transmembrane domain (Figure 3) [131,132]. To facilitate efficient attachment, both spike and Env are glycosylated and furin cleaved during viral maturation. Glycosylation aids immune evasion and is considerably greater on HIV-1 Env than on SARS-CoV-2 spike (Figure 1c). Cleavage of both glycoproteins by the host protease furin generates noncovalently bound subunits of their respective $\mathrm{N}$ - and C-terminal domains, thereby priming each glycoprotein for engagement with subsequent receptors or host proteases. The cellular receptor for SARS-CoV-2 is the widely expressed angiotensin-converting enzyme 2 (ACE2) [133], and it binds via the RBD of spike (Figure 3) [53,134]. Notably, the additional cell surface receptor neuropilin-1, which is highly expressed in the respiratory and olfactory epithelium, has been shown to bind exclusively to the furin-cleaved spike, potentiating SARS-CoV-2 infectivity in these tissues $[135,136]$. Alternatively, SARS-CoV-2 spike has also been shown to interact with the host cell receptor CD147 (basigin) to facilitate viral endocytosis [137]. In contrast to SARS-Cov-2, attachment of HIV-1 occurs via binding of gp120 to the cell surface immunoglobin glycoprotein CD4 (Figure 3), which is expressed on subsets of T cells and macrophages $[49,138]$. Cellular attachment can be initiated or supported by additional cellular membrane proteins such as integrin $\alpha 4 \beta 7[139,140]$.

Upon engagement with their host cell receptors, SARS-CoV-2 spike and HIV-1 Env undergo conformational changes to facilitate virus-host membrane fusion. The conformational changes exhibited by both spike and Env enable the extension of their hydrophobic fusion peptides, which are essential for virus-host membrane fusion and subsequent virus entry into the host cytoplasm. The molecular triggers for these conformational changes are different for both viruses. For SARS-CoV-2, extension of the fusion peptide within the S2 domain is triggered through cleavage by host cell proteases at the S2' site (Figure 3). The canonical entry occurs through membrane fusion directly at the plasma membrane and involves S2' cleavage by the host protease TMPRSS2 at the cell surface following ACE2 engagement [141,142]. Alternatively, SARS-CoV-2 can enter via endocytosis and membrane-fusion-mediated release from endosomes. In support of this second route of entry, the endosome-localized host protease cathepsin-L has been shown to participate in S2' cleavage of SARS-CoV-2 spike at the endosomal membrane, likely following CD147-mediated endocytosis [137,142]. These alternate mechanisms of SARS-CoV-2 fusion provide the virus with independent and redundant avenues of entry, which likely contributes to the broad tissue tropism of this virus. In contrast to SARS-CoV-2, the binding alone of HIV-1 gp120 to its cell surface receptor CD4 is sufficient for triggering conformational changes. These conformational changes expose and stabilize the variable loop V3-binding site for co-receptor engagement at the cell surface [138]. CCR5 and CXCR4 can both act as co-receptors for HIV-1. No co-receptors have been identified for SARS-CoV-2. CCR5 or CXCR4 binding to V3 of gp120 induces further conformational changes to gp120, which, after dissociation of gp120, releases the fusion peptide of bound gp41 for insertion into the host cell membrane (Figure 3) $[143,144]$. Subsequent rearrangement of the heptad repeat regions of gp41 bring the viral and host cell membranes in close proximity for fusion 
and release of the viral capsid into the host cell cytoplasm [143]. The released viral capsid of HIV-1 continues to encapsulate the viral replication components as the pre-integration complex (PIC), until it delivers the HIV-1 dsDNA to the nucleus. Alternatively, the capsid of SARS-CoV-2 immediately uncoats the viral RNA upon entry into the cytoplasm.

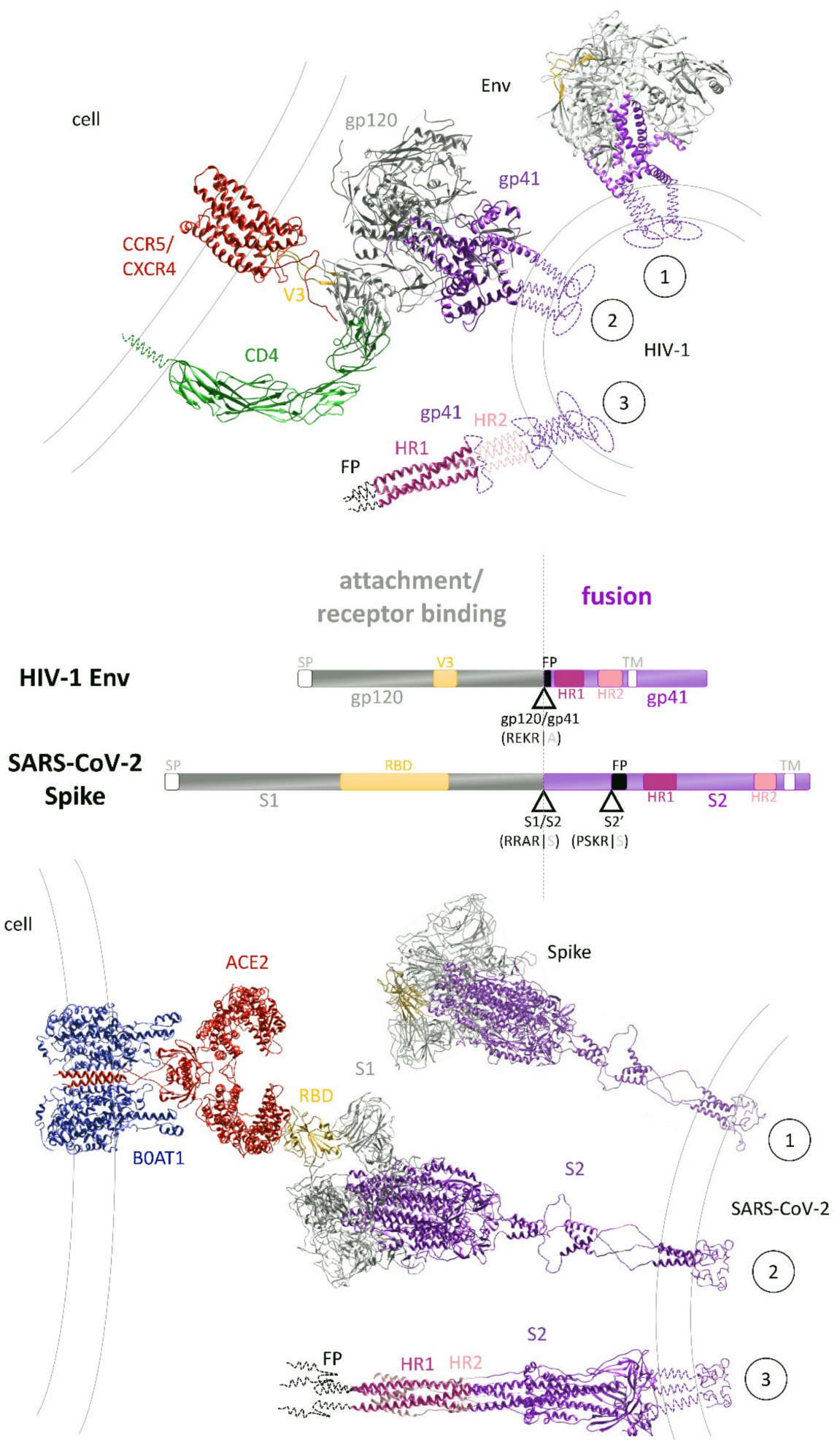

Figure 3. Spike-mediated cellular entry of HIV-1 (top) and SARS-CoV-2 (bottom). Structural model depicting transition/activation states of viral spike proteins during viral entry. (1) Prefusion "closed" state, (2) partially "open" state after interaction of spike proteins with cellular receptors, (3) fusion intermediates after dissociation of cellular attachment 
domains gp120 (HIV-1) or S1 (SARS-CoV-2), which exposes fusion peptides for insertion into the target cell membrane. Schematics of HIV-1 Env and SARS-CoV-2 spike coding genomic regions are shown in the middle with domains colored the same way as shown in the structural models. ACE2: angiotensin-converting enzyme 2, B0AT1: sodium-dependent neutral amino acid transporter, RBD: receptor-binding domain, FP: fusion peptide, and HR: heptad repeat.

\subsubsection{Translation, Transcription, and Reverse Transcription}

The initial stages of SARS-CoV-2 and HIV-1 replication are remarkably different despite both viruses starting with positive-stranded RNA genomes. Immediately after uncoating in the cytoplasm, the SARS-CoV-2 genome acts as mRNA for the translation of two ORFs (Figure 2b). ORF1a and ORF1b produce polyproteins named pp1a and pp1ab. ORF1a encodes pp1a while the larger pp1ab is the fusion product of ORF1a and $O R F 1 b$, resulting from a -1 ribosome frameshift during translation $[47,145]$. Following their proteolytic cleavage into 16 NSP subunits, these polyproteins comprise the complete SARS-CoV-2 replicase-transcriptase complex (RTC), responsible for the transcription of the remaining ORFs as well as the full-length gRNA [47]. Conversely, the HIV-1 genome is reverse-transcribed into dsDNA after entry, a step that is catalyzed by the viral RT prebound to the viral genome (Figure 2a). Interestingly, this reverse-transcription process, which lacks a proof-reading step, is much more error-prone than the transcription of the SARSCoV-2 genome which is supported by a sophisticated proof-reading mechanism $[39,146]$, contributing to the comparatively broad genomic diversity of HIV-1 (Table 1, Figure 4). HIV must transport its nucleic acid to the nucleus via the nuclear pore. Within the nucleus, the PIC is uncoated and the dsDNA complex is integrated into the host genome by the viral enzyme Integrase [147-149]. It is only after integration that the HIV-1 genome is transcribed into mRNAs by host enzymes in the nucleus, which are then transported out and translated in the cytoplasm. HIV-1 achieves productive infection by preferential integration of its viral genome in intron regions of highly expressed host genes $[147,150]$. The chronicity of HIV-1 is caused by latent infection of long-lived memory CD4 ${ }^{+}$T cells and constitutes a major barrier towards a cure of HIV-1 infection [151]. Latent infection is accomplished by integrating HIV-1 into transcriptionally silent regions of the genome of quiescent $\mathrm{CD}^{+} \mathrm{T}$ cells $[152,153]$.

The transcription of subgenomic (sg) mRNAs and their subsequent translation also differs considerably between these two viruses. The SARS-CoV-2 RTC forms at lipid droplet factories within the cytoplasm [47]. There, the NSP12 RNA-dependent RNA polymerase (RdRp) generates both full-length negative-strand RNA, which acts as the template for replicating SARS-CoV-2 gRNA and shorter sgRNAs of the accessory and structural gene-encoding ORFs [47]. Typical of coronaviruses, transcription regulatory sequences (TRSs) upstream of each of these ORFs prematurely terminate negative-strand RNA transcription in a process referred to as discontinuous transcription. The resulting transcripts are a set of structurally polycistronic nested sgRNAs; however, it is assumed that functionally, these transcripts are monocistronic and that only the $5^{\prime}$-most ORF in each sgRNA is translated [154,155]. Once translated from these sgRNAs, the structural proteins spike, E, M, and N package the gRNA to form infectious virions at the ER-to-golgi intermediate compartment for secretion by exocytosis. In addition to these canonical ORFs encoding structural proteins, recent ribosomal-profiling has identified 23 translationally active unannotated SARS-CoV-2 ORFs with currently unknown function [156]. In contrast to SARS-CoV-2, the transcription of the integrated HIV-1 genome is carried out by cellular polymerases in the nucleus and, through means of alternate splicing, gives rise to over 50 viral RNA transcripts [157]. Governed by the cellular export machinery, only fully spliced RNA transcripts are exported from the nucleus for translation. Hence, the HIV-1 gene products can be separated into early and late based on their necessity for intron retention. The early viral transcripts $r e v$, tat, and nef are encoded by fully spliced transcripts and consequently, can be immediately exported for translation, while the remaining genes encoded by partially or unspliced transcripts rely on sufficient levels of Rev to accumulate. Rev binds HIV-1 intron-containing transcripts and enables their alternate export to the 
cytoplasm. The structural Gag and Gag-Pol polyproteins are translated from the unspliced gRNA and consequently are among the last proteins translated. Moreover, Gag is translated from the gag gene, while Gag-Pol is a fusion protein generated by a ribosomal frameshift during translation of the gag gene to the alternate pol reading frame [158]. Once all the HIV-1 structural proteins are translated, virion assembly proceeds at the cell membrane.
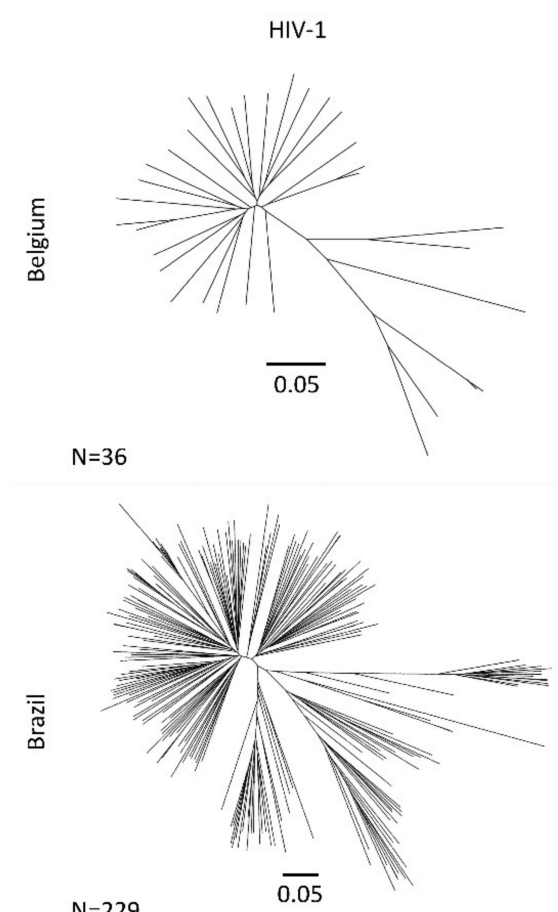

$N=229$

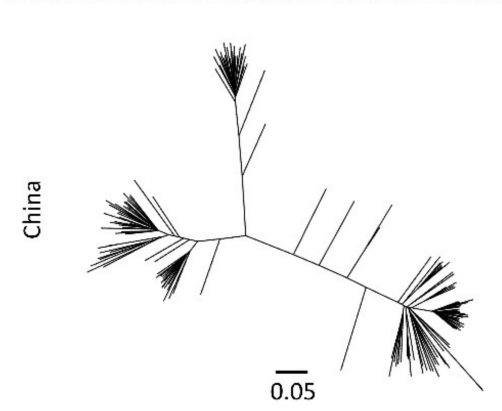

$\mathrm{N}=150$

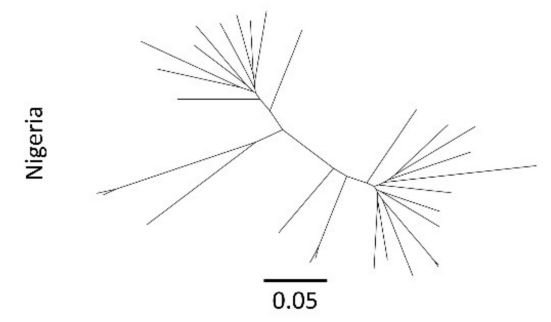

$\mathrm{N}=29$
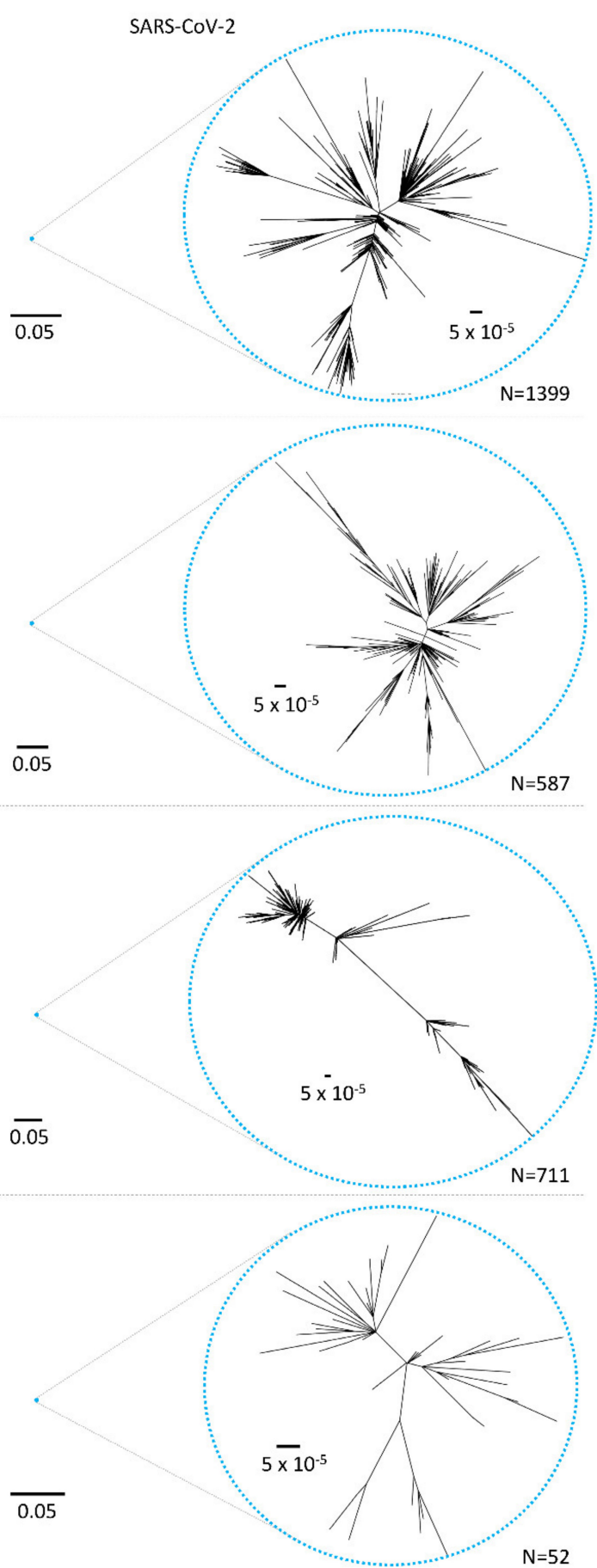

Figure 4. Phylogenetic diversity of HIV-1 and SARS-CoV-2. Maximum likelihood phylogenetic trees (RAxML, 1000 bootstrap replicates) were generated with full length HIV-1 (left) and SARS-CoV-2 (right) genomic sequences from four different countries/continents. For SARS-CoV-2, all available full-length sequences with high coverage were used, deposited to 
GISAID within one year since initiation of the outbreak in mid-December 2019. Comparably, HIV-1 sequences from one entire year were studied, selected based on comparable case numbers $(<1.5$ log difference to the respective SARS-CoV- 2 data set). Study numbers are indicated in the figure. The collection years of the studied HIV-1 sequences were 2016 (Belgium), 2010 (Brazil), 2007 (China), and 2009 (Nigeria). For SARS-CoV-2, the phylogenetic trees are shown both using a best-fit scale (right) and using the same scale as used for the HIV-1 tree (left; tree condensed to a blue point according to the outline of the tree).

Despite their differences in replication strategies outlined above, SARS-CoV-2 and HIV1 also share some similarities that may pose universal targets for therapeutic intervention. Each of these viruses is encapsulated by a replication complex during their replication within the host cytoplasm. The RNA synthesis of SARS-CoV-2 has been shown to occur in ER-derived double-membrane vesicles [159], while the reverse-transcription of HIV-1 occurs within the viral capsid/PIC [160]. These complexes act to segregate immunogenic viral replication intermediates from cytosolic innate immune sensors [161]. Moreover, the translation of the polyproteins of each virus relies on ribosomal frameshift events. During SARS-CoV-2 replication, this frameshift occurs when translating ORF1a and ORF1b to give rise to pp1ab, while in HIV-1 replication, a frameshift gives rise to the Gag-Pol polyprotein. Interestingly, the frameshift efficiency in SARS-CoV-2 is $57 \% \pm 12 \%$ giving rise to only slightly greater expression of ppla than pplab [156], while during HIV-1 replication, the frameshift efficiency is only 5\%, which generates 20 times greater expression of Gag than Gag-Pol [162]. The efficiency of the frameshift during HIV-1 replication is strictly maintained, and any disruption to this rate is detrimental to virus assembly, genome packaging, and maturation [163-166]. In contrast, the regulation and implications of the frameshift giving rise to SARS-CoV-2 pplab are not as well characterized, but likely serve similar regulatory purposes for viral protein expression.

\subsubsection{Virus-Host Interaction and Exploitation of the Cellular Machinery}

Viral pathogens depend on the cellular machinery to propagate. Thus, it is evident that both HIV-1 and SARS-CoV-2 redirect large parts of the cell-intrinsic biological processes for their opportunistic use involving several thousands of genes and proteins [44,167-171]. While the complex network of interactions between these viruses and their host cells has only been disentangled rudimentarily, the viral strategies of exploiting cellular components and programs appear manifold in both HIV- 1 and SARS-CoV-2 infection. In CD4 ${ }^{+}$ T cells, the primary target of HIV-1, more than $70 \%$ of all expressed genes are modulated in concordance with key steps of HIV-1 viral replication and more than $50 \%$ of the longitudinal variability in the host transcriptome can be explained by correlations with main phases of the viral life cycle [44]. This leads to a massive change in cellular physiology with a pronounced early transcriptional shutdown, followed by a progressive, fine-tuned upregulation of parts of the cellular machinery. These changes support viral processing and reproduction and are only partly due to the cell's triggered defense mechanisms. Single-cell transcriptome studies revealed that HIV-1 targets heterogeneous cells including subpopulations with low expression of interferon-stimulated genes [150]. Proteomic studies confirmed HIV-1 protein-mediated surface downregulation of HIV-1 restriction factors such as SERINC3/5 and interference with $\mathrm{CD}^{+} \mathrm{T}$ cell mitogenesis [168]. A study of $\sim 9000$ proteins in primary human $\mathrm{CD}^{+} \mathrm{T}$ cells across multiple donors revealed $650 \mathrm{HIV}$ 1-dependent changes against the background of T cell activation [167]. Accessory HIV-1 proteins including Vif, $\mathrm{Vpr}, \mathrm{Vpu}$, and Nef played a dominant role, accounting for $46 \%$ of the HIV-1-specific proteomic changes in primary T cells.

Similar to HIV-1, SARS-CoV-2 profoundly interacts and modifies the cellular physiology both on the transcriptional [169-173] and protein levels [128,170,174,175]. Host responses to SARS-CoV-2 vary substantially depending on viral load, infection stage, disease severity, body tissue, and cell type as well as age and sex of the host $[172,176,177]$. Coupled to the induction of an antiviral response, the expression of the SARS-CoV-2 receptor and interferon-responsive gene ACE2 is upregulated by the infected host cell 
in a viral load-dependent manner. In contrast, B cell-specific proteins and neutrophil chemokines are elevated in individuals with lower viral load. Transcriptional levels of the SARS-CoV-2 spike-processing host protease TMPRSS2 depend on infection time point and cell type [171,172]. Time series transcriptome profiling of Calu-3 cells infected in vitro with a clinical SARS-CoV-2 isolate revealed a strong upregulation of TMPRSS2 mRNA within the very first few hours post infection [171], whereas at later time points, the levels revert to baseline or even slightly below [171,172]. Males and older individuals exhibit impaired transcriptional activity affecting trafficking and/or antiviral responses through the reduced function of cytotoxic T cells, B cells, and natural killer cells [172]. Proteomic studies further showed that SARS-CoV-2 reshapes cellular translation, splicing, carbon metabolism, protein homeostasis, and nucleic acid metabolism [174]. In addition to viral proteins, it was shown that SARS-CoV-2 RNA directly and specifically binds and/or modulates a broad network of human proteins in infected human cells [178], and host mitochondria serve as an organelle platform for anti-SARS-CoV-2 immunity [179]. Approximately one-third of the cellular RNA-binding proteins (RBPs) are remodeled upon SARS-CoV-2 infection, and inhibition of these RBPs impairs SARS-CoV-2 infection [180].

\subsubsection{Proteolytic Processing of Viral Proteins}

A central component of viral replication, including that of SARS-CoV-2 and HIV-1, is the proteolytic processing of viral proteins, which serves to orchestrate genome replication, assembly and maturation. This process involves the cleavage of viral proteins mediated by proteases that are encoded either by the virus or the host. Virally encoded proteases are typically responsible for the autocatalytic excision from polyproteins in which they reside, and for subsequent proteolytic processing of the remaining polyprotein components (i.e., 3CL-pro in pp1a/pp1ab or PR in Gag-Pol). While minimizing coding space within the viral genome, this polyprotein processing also coordinates synchronized translocation of tethered viral proteins to assembly sites within the host cell [181]. In addition to processing by viral proteases, viral proteins, including those of SARS-CoV-2 and HIV-1, are also cleaved by host proteases (i.e., furin), most notably to mediate viral maturation, which primes progeny virions for efficient entry into new cells. The critical functional role of post-translational viral protein cleavage proposes this process as an attractive target for antiviral therapeutic development.

Characteristic for viruses with a positive-sense RNA genome, SARS-CoV-2 and HIV-1 both encode polyproteins that undergo proteolytic processing by virally encoded proteases. However, the replication stage at which the polyprotein proteolytic processing occurs is different between SARS-CoV-2 and HIV-1, reflecting their alternate replication strategies. For SARS-CoV-2, polyprotein processing occurs post viral entry and prior to viral replication. The two SARS-CoV-2 polyproteins pp1a and pp1ab are translated from the incoming positive-sense RNA genome and are proteolytically processed by two cysteine proteases, papain-like protease (PL-pro) and 3-chromtrypsin-like protease (3CL-pro, or main protease; M-pro), which reside within NSP3 and NSP5, respectively, and are released auto-catalytically (Figure 1) [182]. PL-pro catalyzes the cleavage of NSP1-3 and the amino-terminal of NSP4, while 3CL-pro cleaves the carboxyl terminal of NSP4 as well as the remaining NSP5-16 [183]. These cleavage events are essential for the subsequent steps of SARS-CoV-2 replication, and consequently, their inhibition through therapeutic intervention is a topic of ongoing research efforts (Figure 2) $[48,184]$. In the HIV-1 life cycle, polyprotein processing occurs at later stages, post viral replication and during viral assembly. Indeed, proteolytic cleavage of HIV-1's integral structural and replicative proteins Gag and Gag-Pol typically occurs during virion assembly and maturation at the cell surface or within the budded virion. Cleavage is performed by the aspartic HIV-1 protease (PR), itself harbored within the packaged Gag-Pol polyprotein and released auto-catalytically (Figure 1) [185]. The PR cleavage of Gag generates the main structural proteins MA, CA and NC, which subsequently rearrange to form the mature, infectious particle [186]. The PR cleavage of Gag-Pol, while also generating the structural proteins, additionally gives rise 
to the TFP, PR, RT, RNase $\mathrm{H}$ and IN proteins required for initial reverse-transcription and integration upon entry into a new cell [186]. Incompletely processed HIV-1 polyproteins fail to covert the assembled virus particle into a mature infectious virion, and HIV-1 PR has consequently been a target of anti-HIV-1 therapies for numerous years (Figure 2) [186,187].

In addition to polyprotein cleavage by viral proteases, the life cycles of both HIV-1 and SARS-CoV-2 include proteolytic processing of their receptor-binding glycoproteins, which are performed by host proteases. These events occur late in the life cycle for both viruses, during a process called viral maturation. Both viruses utilize the host furin-like proteases for cleavage of their glycosylated receptor-binding proteins within the trans-golgi network during virion assembly. The SARS-CoV-2 spike protein possesses a furin cleavage site at the S1/S2 junction [188], which has been demonstrated to be critical for SARS-CoV-2 pathogenicity $[119,141,189-191]$. It enhances the binding affinity of spike to ACE2 by three orders of magnitude [116], but is not entirely essential for SARS-CoV-2 infection, possibly by the secondary spike cleavage event, which can be mediated by proteases other than furin [28,190,191]. The HIV-1 Env polyprotein cleavage by furin produces the receptorbinding gp120 and transmembrane gp41 subunits (Figure 3) [32,192-195]. In contrast to furin-mediated cleavage of SARS-CoV-2 spike, the cleavage of HIV-1 Env appears essential for HIV-1 entry and infection [196-198].

Unlike HIV-1 and most other viruses, SARS-CoV-2 possesses an additional cleavage site within its receptor-binding glycoprotein spike, named S2', which facilitates exposure of its fusion peptide (Figure 3). This second cleavage is mediated by alternate host proteases TMPRSS2 and Cathepsin-L. While initial discrepancies in findings disputed the contribution of either protease, a recent study has determined a spatial delineation underpinning their alternate contributions [142]. It is now understood that both proteases may cleave spike to facilitate fusion; however, TMPRSS2 acts to cleave spike at the cell surface, while Cathepsin-L cleaves spike within the endosome, which likely contributes to the broad tropism displayed by SARS-CoV-2 [142]. Overall, it is apparent that host proteases are employed by both viruses during maturation and in the case of SARS-CoV-2 also during host cell recognition, which primes their receptor-binding glycoproteins for subsequent entry.

\section{Humoral Immune Responses}

Antibody $(\mathrm{Ab})$ immune responses play a central role in protecting the host from viral infections [199]. Ab-mediated protection is primarily attributed to the Ab binding and neutralization capacity (see Section 5.1), complemented by Ab Fc-mediated responses (see Section 5.2). The Abs' high specificity to defined viral epitopes imposes a strong selection pressure, which may favor the selection of viral escape mutations (see Section 5.3). In all, the relationship between Abs and viruses uniquely shapes their co-evolution in virus-infected individuals and entire populations.

\subsection{Antibody Binding and Neutralization}

In natural HIV-1 infection, HIV-1-specific Abs are elicited within the first weeks of infection. These include IgM and subsequently class-switched IgG and IgA, which are mainly directed against the immunogenic, highly variable Env gp41 and gp120 regions such as V3 at this initial stage. These early non- or weakly neutralizing Abs are narrow, mostly strain specific, and predisposed to rapid immune evasion [200-202]. Broadly neutralizing Abs (bnAbs) occur only in a small percentage of HIV-1-infected individuals $(\sim 10 \%)$, requiring a few years of continuous antigenic stimulation and maturation, mostly involving high rates of somatic hypermutation [203]. In HIV-1-infected individuals, the development of bnAbs, or high neutralization levels in general, are not associated with better clinical outcome/slow progression, but in turn, correlate with severity of disease and high viral load (Figure 5) [204-206]. Knowledge gained from the tedious process of natural bnAb development is currently translated into germline-targeting vaccine strategies with sequential boosting [207]. Similar to SARS-CoV-2, neutralization is considered the lead effector function to protect from HIV-1 infection, since passive administration of bnAbs in ani- 
mal models of HIV-1 infection can confer protection against viral challenges [199,208,209]. This strategy is currently tested in human clinical trials [210,211]. However, while vaccines can induce sufficiently potent bnAbs against SARS-CoV-2 [212-214], and COVID-19 convalescent individuals acquire protective immunity through natural infection [215], it has not been possible to induce broadly protective Abs by HIV-1 vaccines [81] and primary HIV-1 infection does not adequately protect from superinfection [216-218]. Ab responses induced in participants of HIV-1 human vaccine trials such as RV144 were mostly non- or weakly neutralizing, waned rapidly, and/or suffered from rapid viral escape (see Section 5.3) $[81,86,219,220]$.

In contrast to HIV-1 infection, natural SARS-CoV-2 infection rapidly induces neutralizing Abs (nAbs) targeting primarily the spike RBD and N-terminal-domain (NTD) regions and encompassing a broad range of heavy chain and light chain $\mathrm{V}$ genes [221]. Most individuals develop very similar $\mathrm{nAb}$ responses with moderate breadth and plasma neutralization activity that require only low rates of somatic hypermutation [222]. Prolonged viral replication in immunocompromised hosts may favor the generation and selection of $\mathrm{nAb}$ escape mutants, which in turn drives $\mathrm{Ab}$ affinity maturation and eventually enhanced neutralization breadth and potency [223]. In humans, previous SARS-CoV-2 infection and anti-spike $\mathrm{Ab}$ seropositivity significantly reduce the risk of SARS-CoV-2 reinfection [215,224-229], which is in line with vaccination outcome analyses [230-236] altogether implying that SARS-CoV-2 binding and/or nAbs exert protective effects. Consequently, neutralization levels have been found highly predictive of immune protection with seven current vaccines and in convalescent cohorts, and provide an evidence-based model of SARS-CoV-2 immune protection [237]. Non-human primate models of SARS-CoV-2 infection corroborated these findings and suggest that $\mathrm{nAb}$ play the leading role in protection from SARS-CoV-2 infection $[87,238]$. In rhesus macaques, Ab-based protection or their therapeutic potential is dose dependent. Although low Ab titers were sufficient to protect rhesus macaques from SARS-CoV-2 infection or reinfection, higher Ab titers were required to achieve a drop in viral load once infected. Furthermore, cellular immunity contributes to viral control and may compensate waning or insufficient Ab-mediated responses [87,239] (see Section 5.1), e.g., CD8 ${ }^{+} \mathrm{T}$ cell depletion reduced the protective efficacy of natural immunity against SARS-CoV-2 reinfection in convalescent animals [87]. In addition to $\mathrm{nAb}$ responses against the spike NTD and RBD regions, phage display screenings for binding Abs targeting linear epitopes identified common responses in COVID-19 patients against the fusion peptide and the linker region upstream of the HR2, however with variable escape mechanisms [240]. These findings are in line with a recent report stating that the $\mathrm{Ab}$ binding response in COVID-19 convalescent individuals converges in $>80 \%$ to non-RBD epitopes [241]. The early anti-SARS-CoV-2 binding and nAb response is dominated by IgM, which wanes rapidly. IgA and IgG peak subsequently, and IgG-mediated neutralizing responses are most durable and persist over months, mirrored by neutralization half-lives of a few months in serum but up to $>8$ months in purified IgG samples [242-245]. The persisting $\mathrm{Ab}$ response can be attributed to a maturing humoral immunity driven by a sustained SARS-CoV-2 antigenic stimulation in the gut of COVID-19 patients [246]. Similar to HIV-1, higher anti-SARS-CoV-2 Ab and neutralization levels are preferentially found in severe cases [55,247-250]. However, COVID-19 survivors exhibit enhanced neutralization potency [247] and a more balanced Ab maturation pathway [251] that might even be critical for survival [252]. More recently, it was shown that severely ill patients do not necessarily mount higher overall humoral responses than mild cases, but are characterized by a delayed kinetic of the anti-spike IgG and $\mathrm{nAb}$ response [253]. Neutralization is primarily mediated by receptor-blocking $\mathrm{nAbs}$, and they can either inhibit or enhance syncytia formation [254]. 
(a) HIV-1 2 progressor
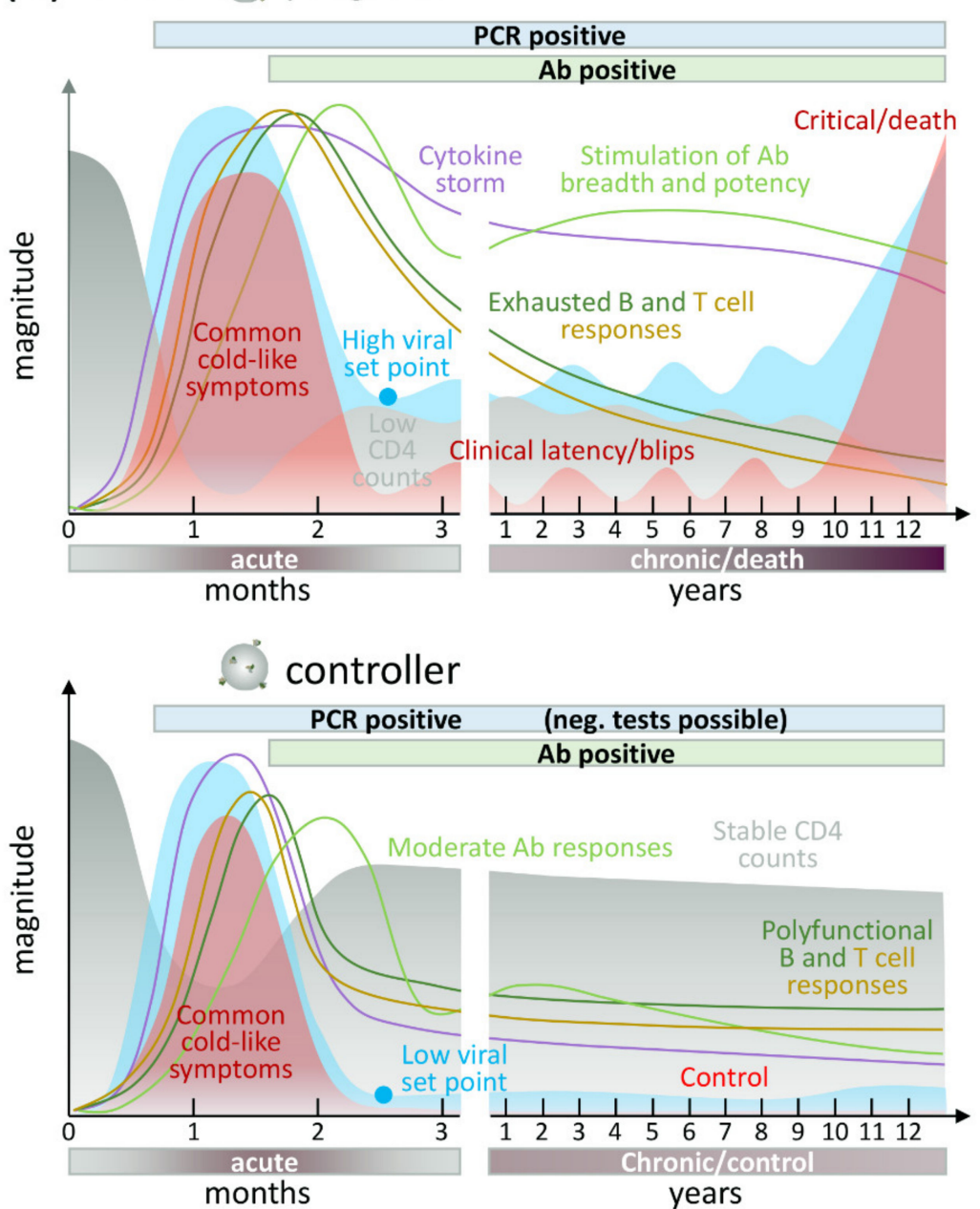

Time since transmission (b) SARS-CoV-2 severe
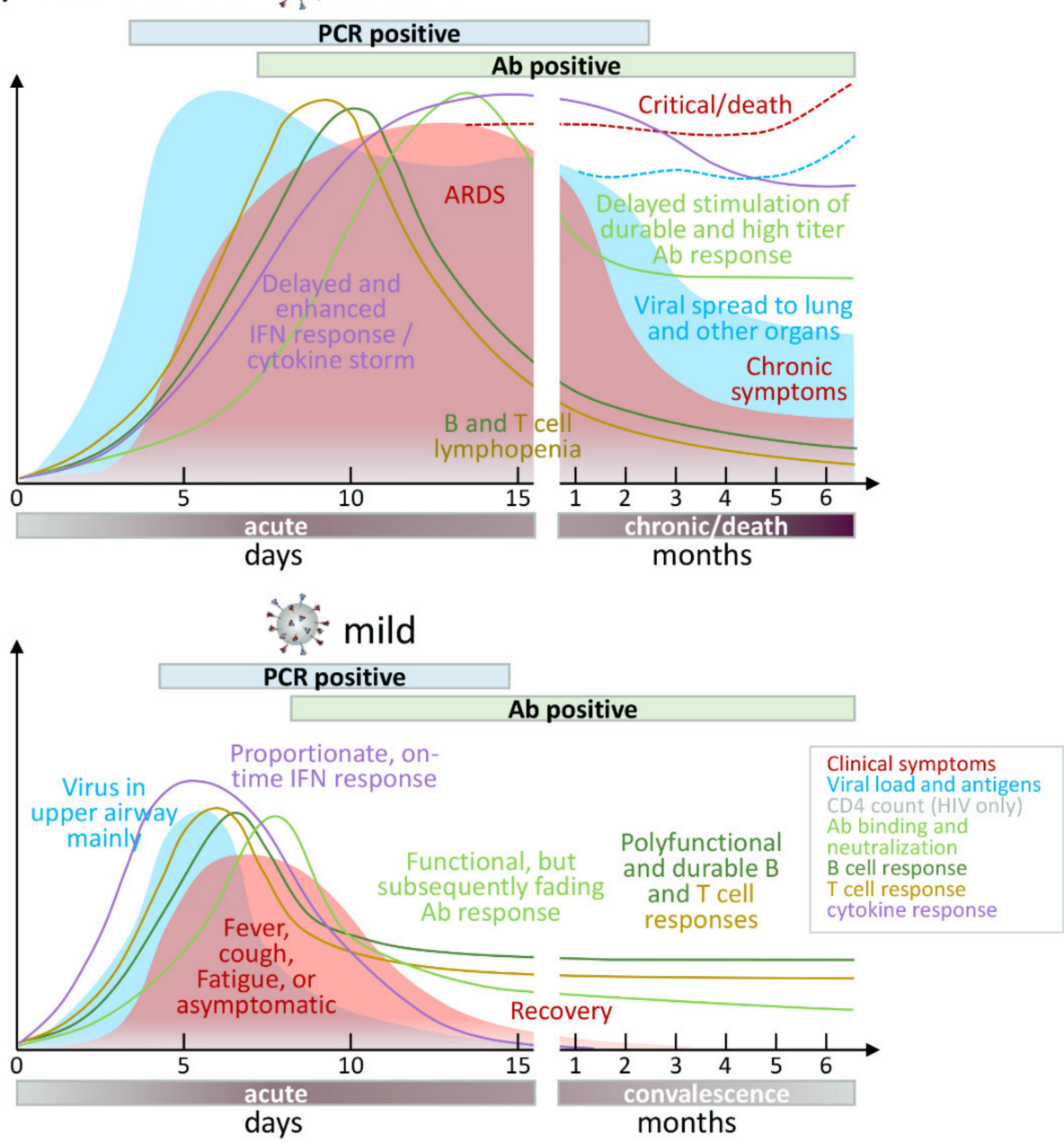

Time since transmission

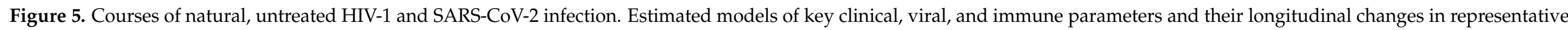

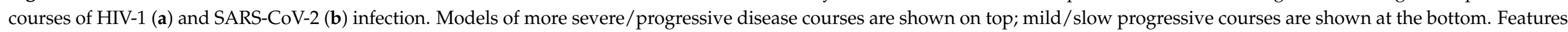
are color-coded according to the legend and key features directly annotated. 
Of note, a recent study showed that some Abs against the spike NTD induce the open spike conformation and thus enhance the binding capacity to ACE2 and infectivity of SARSCoV-2 [255]. Mutational and structural analyses indicated that all infectivity-enhancing Abs target a common site on the NTD and shar a divalent binding mode. Abs specific for the infectivity-enhancing site on the NTD were detected at high levels in severe patients. The identified mechanism of antibody-dependent enhancement (ADE) of viral infection is Fc receptor-independent. It differs from the Fc receptor-dependent ADE identified with other viruses in having a lower impact on infection, but affecting a broader range of cells including ones that do not express Fc receptors [255-257]. Excess amounts of nAbs appear to suppress ADE in most cases of SARS-CoV-2 infection or vaccination; however, the precise functional consequences of infectivity-enhancing Abs on SARS-CoV-2 pathogenicity and vaccines, and their differential impact on variants remain elusive.

In addition to SARS-CoV-2 spike, the $\mathrm{N}$ and ORF $3 \mathrm{~b}$ and 8 proteins are highly immunogenic with implications as serological markers [258]. Qualitative differences in early $\mathrm{Ab}$ profiles point to elevated $\mathrm{Ab}$ responses to the $\mathrm{N}$ protein in deceased individuals [259]. $\mathrm{Ab}$ immune responses have mainly been studied in the blood, whereas little data exist about the responses at the local sites of infection such as the respiratory system. Of interest, the mucosal immune system comprises the largest part of the immune system. On-site production of secretory IgA (sIgA) by far exceeds all other immunoglobulin isotypes, which renders the mucosa, as site of viral entry, prepared for the initial wave of adaptive defense [260]. Consequently, anti-SARS-CoV-2 IgG and IgM levels, which mainly transudate from the blood into the mucosa, correlate well between both compartments. In contrast, IgA was found to be more abundant in the mucosa, particularly early during disease, which supports the hypothesis that SARS-CoV-2 infection triggers local sIgA production [261,262].

Combining immunological and epidemiological analyses on seasonal coronaviruses has shown that infection-blocking immunity wanes rapidly, but disease-reducing immunity is long-lived, which suggests a model of SARS-CoV-2 transitioning within years to endemicity with mitigated pathogenicity [263].

\subsection{Antibody Fc-Mediated Functions}

Antibody $\mathrm{Fc}$-mediated functions complement $\mathrm{Ab}$ neutralization functions and provide a link between Ab- and cell-based immunity (e.g., NK cells and phagocytes) or soluble effectors (e.g., complement) [264,265]. As such, Fc-mediated Ab functions can act hand in hand with neutralization or as an additional line of defense before or after neutralization.

In HIV-1 infection, Fc-mediated effector functions have been studied in detail in recent years, particularly antibody-dependent cellular cytotoxicity (ADCC) and antibodydependent cellular phagocytosis (ADCP) [266,267]. Using a quantitative approach in HIV1-infected humanized mice and Simian-HIV (SHIV)-infected rhesus macaques, 25-45\% of the total antiviral activity of anti-HIV-1 mAbs was attributed to Fc-mediated effector functions [268]. In support of that, mAbs with non-functional Fc-receptors had dramatically decreased capacity to protect animal models from SHIV infection [269]. Since the isolated depletion of complement binding had no impact on the protective activity, Fcmediated cellular responses appear to play the dominant role. Indeed, Fc-mediated cellular responses such as ADCC and ADCP have been associated with protection from HIV-1 disease progression and protection from (S)HIV infection in animal models or in a human vaccine trial $[81,266,270,271]$. For example, ADCC responses in the presence of low plasma IgA/IgG ratios correlated with protection from infection in a large human vaccine trial with partial efficacy (RV144) [86,220,272-274], yet a complete mechanistic explanation remains elusive $[81,266]$. Furthermore, $\mathrm{Fc}_{\mathrm{C}} \gamma$ phenotyping in vaccinees of the same trial revealed that distinct single-nucleotide polymorphisms (SNP) in the FC $\gamma \mathrm{R} 2 \mathrm{C}$ gene conferred 91\% vaccine efficacy against HIV-1-carrying immunodominant epitopes in Env that experienced vaccine selection pressure. In contrast, individuals with a different SNP exhibited only 15\% vaccine efficacy [275]. 
Many studies have shown a tight linkage between $\mathrm{Ab}$ Fc-mediated effector functions and neutralization in HIV-1 infections [269,276-280]. A recent study showed that the neutralization activity of an anti-HIV- $1 \mathrm{mAb}$ was potentiated $>5000$-fold in vitro when expressing the IgG high-affinity Fc receptor FC $\gamma$ RI compared to the same mAb without [278]. Moreover, the antisera from animals immunized with the respective $\mathrm{mAb}$ epitope-based vaccine neutralized diverse HIV-1 clades, including more resistant tier-2 viruses, in an FC $\gamma$ RI-dependent manner [278]. Nonetheless, the mutual impact between Fc-mediated functions and neutralization can vary considerably as it was shown, for example, that Fc-mediated activity was partially redundant for a very potent bnAb [281], and differences in antibody binding affinity for HIV-1 and SIV Env uncoupled mAb-mediated ADCC from neutralization [282]. Fc-mediated functions are influenced by the antigenicity and conformation of the infecting strain/molecular clone, $\mathrm{Ab}$ binding levels, $\mathrm{Ab}$ specificity, $\mathrm{Ab}$ orientation on the bound antigen, gp120 shedding, capacity to form multivalent antigen$\mathrm{Ab}$ complexes, degree of internalization of antigen-Ab complexes, and killer cell receptor ligand expression (e.g., NKG2D) [266,280,283-286].

In SARS-CoV-2 infection, data on the impact of Fc-mediated effector functions are still unfolding, but similar to HIV-1, these effector functions appear to be critical [239,287,288]. Studies in non-human primates demonstrated that Fc-mediated functions correlated with protection from SARS-CoV-2 infection [289]. This was confirmed by studies in mice and hamsters, where nAbs provided better protection when coupled with Fc-receptor functionality $[287,290,291]$. Fc-effector functions are elicited in symptomatic and asymptomatic COVID-19 individuals, but they are elevated in severe cases [288]. COVID-19 non-survivors had a higher incidence of compromised Fc-receptor binding and effector functions, implying a crucial role for $\mathrm{Ab} \mathrm{Fc}$-effector functions in limiting severe disease and reducing patient mortality [251]. An in vitro model of ADCC, using full-length spike proteins expressed on the surface of a target cell line, and PBMCs from healthy individuals serving as effector cells, provided additional mechanistic insights. In this model, the ADCC activity of convalescent plasma decreased only modestly compared to the more pronounced decrease in neutralization activity. Substantial ADCC activity was maintained in $85 \%$ of donors plasma up to eight months post symptom onset and strongly correlated with plasma IgG responses [242]. Notably, three weeks post vaccination with an mRNA vaccine, a time point at which vaccine efficacy is estimated to be $>90 \%, \mathrm{nAb}$ responses are still mostly absent, but anti-SARS-CoV-2 ADCC responses well developed [239]. This implies a possible role for Fc-mediated effector functions and other cellular responses in vaccine-mediated protective effects. The collected data so far suggest a vital role for Fc-mediated effector functions in sustained protection from reinfection and vaccine-induced protection.

\subsection{Antibody Escape and Mutant Variants}

HIV-1 and SARS-CoV-2 Ab escape is based on similar principles of immune pressure exerted by Abs on their targeted viral epitopes [292]. However, the strength and timing of the driving immune forces, and the capacities to evade these forces are very different in both viruses. Important discriminative factors are the acute nature of SARS-CoV-2 infection, resulting in a small temporal window of active replication and adaptation, combined with a low mutation rate due to the proof-reading mechanism of the SARS-CoV-2 polymerase complex [146]. This contrasts with the chronic nature of HIV-1 infection that allows for a lifelong ongoing viral replication and adaptation with a high mutation rate in the absence of proof-reading by the HIV-1 polymerase complex. Consequently, HIV-1 immune escape is a constant factor in almost every HIV-1-infected individual, whereas SARS-CoV-2 immune escape is rare and seems to occur preferably in immunocompromised individuals with prolonged viral replication and fostered by treatment with $\mathrm{mAbs}$ or convalescent plasma (blood plasma from a donor who has recovered from COVID-19) (Figure 6) [293-297]. 

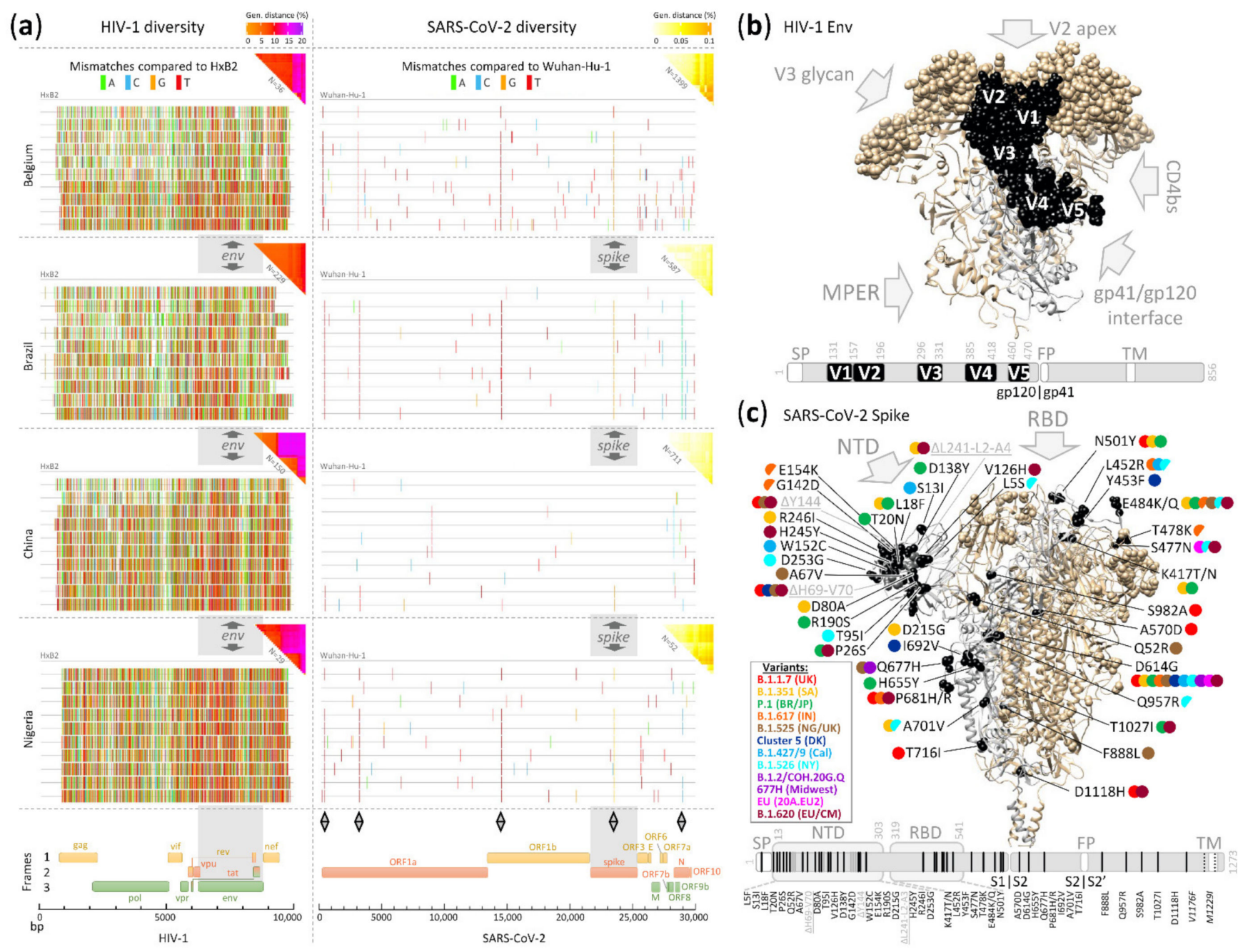

Figure 6. (a) Mutational landscape of HIV-1 and SARS-CoV-2. Highlighter plots indicating mutations/mismatches of HIV-1 and SARS-CoV-2 genomes from four studied countries compared to the references HxB2 (HIV-1, left) and Wuhan-Hu-1 (SARS-CoV-2, right). Base pair mutations are shown as colored tics according to the color code on top. Genome maps are shown at the bottom. Gray diamonds indicate recurrent SARS-CoV-2 mutations. Analyses of ten representative sequences are shown that covered all major branches of the phylogenetic trees in Figure 4. The pairwise genetic distances of the entire set of study sequences per country are summarized in triangle heatmaps (upper right corner of each panel) with colored ranges from white to yellow, orange, red, pink, and purple according to genetic distances from low to high (color code indicated on top). The envelope region (env) of HIV-1 and the spike region (spike) of SARS-CoV-2 are indicated by gray bars and arrows. (b) Variable domains in HIV-1 Env (all in gp120) are highlighted in the structural Env trimer model (\#6wpu) and the gene map shown below. Variable domains are shown in sphere representation in the structure, colored in black, and labeled in one monomer. In the gene map, the variable domains are shown in black and labeled. The Env epitope regions of five major bnAb classes are indicated by arrows and labeled. (c) Amino acid mutations in globally emerging SARS-CoV-2 variants are shown in a SARS-CoV-2 spike structure (S.pdb) [89] and a gene map. The mutations are shown in sphere representation and highlighted in one monomer in the structure. Amino acid replacements are displayed and labeled in black and deletions in gray. The mutations in emerging variants of concern are indicated by circles colored according to the legend to the left; half-circles indicate that mutations occur in only a fraction of variant sequences. The main sites of vulnerability to nAbs are indicated by gray arrows (RBD and NTD). The two most C-terminal mutations are only shown in the gene map, indicated with a dotted line and labeled in italic, i.e., V1176F and M1229I, occurring in P.1 and cluster 5 variants, respectively. Cleavage sites and important amino acid positions, including those of all HIV-1 variable domains and SARS-CoV-2 NTD and RBD domains, are indicated. CD4bs: CD4-binding site; FP: fusion peptide; MPER: membrane-proximal external region; NTD: N-terminal domain; RBD: receptor-binding domain; SP: signal peptide; TM: transmembrane domain. 


\subsubsection{HIV-1's Rapid and Continuous Escape}

The Ab response early after HIV-1 infection predominantly targets hypervariable regions such as the protruding V1-V5 loops and parts of gp41 of the autologous strain. Immune escape to the early non- or weakly neutralizing Abs occurs promptly and extensively without considerable loss of viral fitness (Figure 6) [200-202,298]. HIV-1 Ab escape is a continuous process and occurs through different mutational pathways involving amino acid replacements, insertions, increasing variable loop lengths, deletions, charge changes, conformational blocking, and remodeling/adding shielding glycans. These modulations are largely driven by $\mathrm{nAb}$ pressure or to functionally adapt/optimize cellular receptor usage [299-306]. The mutual pressure exerted by nAbs on the virus and by the mutated/escaped viruses on the immune response leads to an arms race of $\mathrm{Ab}$-virus coevolution, which allows the development of bnAbs in a small percentage of HIV-1-infected individuals [307-309]. Anti-HIV-1 bnAbs require lengthy and complex maturation pathways to develop unusual features such as long heavy chain complementarity determining 3 regions, high levels of somatic hypermutation, extensive insertion-deletion events (indels), and auto- or poly-reactivity. These bnAbs principally target semi-conserved regions or conserved glycan sites on HIV-1 Env. Key regions are the membrane-proximal external region (MPER) of gp41, the CD4-binding site (CD4bs), the gp120/gp41 interface, the V3 glycan region, and the apical V2 glycan region (Figure 6), complemented by a few additional, recently discovered bnAb epitopes involving the fusion peptide, silent face, $\mathrm{V} 3$ crown, and the V2V5 corridor [309-316]. Consequently, natural HIV-1 infection is characterized by an enormous viral diversification, which can generate close to $5 \%$ HIV-1 genetic diversity in singly-infected individuals $[41,42,271]$ with substantial compartmentalization of HIV-1 evolutionary events across anatomical sites $[317,318]$.

\subsubsection{SARS-CoV-2 Mutates on a Low but Constant Level, Yielding Mutant Variants over Time}

In contrast to HIV-1, intra-patient evolution in SARS-CoV-2 is restricted to mostly $<0.05 \%$ genetic distance. Differences in variant distribution between upper and lower respiratory tract have been observed; however, the number of minority variants per patient usually remains $<30 \%$ based on only a few variants (Table 1) [43,319-325]. A higher intrapatient evolution of SARS-CoV-2 yielding several tens of variants appears to be associated with prolonged replication, as frequently found in more severe cases, older individuals, and particularly immunocompromised patients [43,223,293-297,326,327]. Nonetheless, in most SARS-CoV-2 infections, there is one dominant variant throughout the course of the disease and upon onward transmission [324]. Animal experiments on viral evolution and transmission suggest that within-host SARS-CoV-2 variation is predominantly influenced by genetic drift and purifying selection [328]. Due to the low diversity evolving per patient during the comparably short course of infection, the majority of studies focus on population-wide mutation and evolution analyses (Figures 4 and 6).

SARS-CoV-2 variants known to date acquired mutations in different protein-encoding regions along the full SARS-CoV-2 genome; however, mutations in spike were detected most abundantly, suggesting selective pressure on spike in particular (Table 2, Figure 6). During the first phase of the SARS-CoV-2 pandemic (early and mid-2020), spike mutations remained rare, except for D614G, which subsequently became dominant. In vitro studies with pseudoparticles carrying spike showed that D614G does not seem to confer significant $\mathrm{Ab}$ immune escape, but renders spike proteins more stable, increases spike density on the virion surface, and increases production of pseudovirions and thus their infectivity. In vivo studies with authentic SARS-CoV-2 further showed that D614G enhances replication and transmission. [329-336]. During the second year of the pandemic (end of 2020 and 2021), new SARS-CoV-2 variants emerged, subsequently replacing old variants [337]. Some of these second-year spike mutations seem to confer partial neutralization resistance, as measured in in vitro assays with convalescent or vaccine sera [338-343]. Available potent vaccines at optimal dosing can induce multiple times higher $\mathrm{nAb}$ titers than convalescent 
sera $[237,339,344,345]$ and might thus have a broader window to compensate for partial $\mathrm{Ab}$ escape. The enrichment of spike mutations (Table 2, Figure 6) suggests that Ab-mediated immunity, either obtained by SARS-CoV-2 infection or by vaccination, may have exerted critical selective pressure [85]. In the future, it seems possible that selective pressure brought upon by adaptive immunity to SARS-CoV-2 in increasing parts of the general population could further promote selection of variants with a distinct Ab-escape phenotype.

Spike mutations of emerging mutant variants mainly accumulate in three regions: (1) RBD, (2) NTD, and (3) around the S1/S2 cleavage site (Figure 6). RBD and NTD play essential roles as target sites for $\mathrm{nAbs}$, directed in $>90 \%$ of cases against RBD, complemented by lower percentage nAb activity against NTD [221,249,346,347]. Consequently, these sites are also prominent sites for $\mathrm{nAb}$ escape mutations. The S1/S2 cleavage site is functionally important, and mutations at the S1/S2 interface, as primarily shown for D614G in vitro and in vivo, can modify viral entry, transmission, and replication [119,333]. Four mutant variants that spread supra-regionally were classified variants of concerns (VOCs). These VOCs include lineages identified in the UK (B.1.1.7, Alpha) [348], in South Africa (B.1.351, Beta) [349], in Brazil/Japan (P.1, Gamma) [350], and more recently in India (B.1.617.2, Delta) [351,352]. B.1.1.7, B.1.351, and P.1 share the N501Y mutation in RBD in addition to the D614G mutation around the S1/S2 cleavage site (Table 2, Figure 6). Epidemiological studies suggest that B.1.1.7 is associated with higher viral loads in patients $[353,354]$, a $>40 \%$ increased epidemiological growth [355-357], a longer duration of acute infection [358], less effective clearance by innate and adaptive immune responses [359], and increased severity/death rate, particularly in patients of higher age and with comorbidities [360-363]. The B.1.1.7 variant acquired an enhanced affinity to ACE2 [364] while maintaining sensitivity to $\mathrm{nAb}$ responses though with 2-9 times reduced $\mathrm{nAb}$ titers in vaccinees and convalescent individuals [364-367]. Spike mutations present in B.1.1.7 frequently confer resistance to NTD-directed $n A b s$, whereas neutralization by RBD-specific $n A$ bs remains largely unaffected [368]. Recently, B.1.1.7 variants were detected in the UK and the USA that additionally carry the E484K mutation (VOC-21FEB-02) and render these variants more resistant to monoclonal and polyclonal $\mathrm{nAb}$ responses [369,370].

N501Y appears to play an important role in the evolutionary success of VOCs by increasing spike affinity for ACE2 [371] as well as viral infectivity and virulence, as shown in a mouse model of SARS-CoV-2 infection [372]. Molecular dynamics simulations with B.1.351 and P.1 variants indicate that E484K confers a higher RBD affinity to ACE2 [373]. Furthermore, neutralization assays using viruses pseudotyped with variant or single-mutant spike proteins as well as virus selection experiments under $\mathrm{nAb}$ selection pressure indicated that $\mathrm{E} 484 \mathrm{~K}$ is a primary escape and resistance mutation. E484K was responsible for near complete resistance against multiple NTD and RBD mAbs and $>10$ and $>30$ times lower $\mathrm{nAb}$ titers in vaccinees and convalescent individuals, respectively. N501Y or K417N are additional mutations, all in RBD, conferring reduced $\mathrm{nAb}$ activity in SARS-CoV-2 vaccine and convalescent sera $[338,339,342,343,343,374-381]$. These results could be recapitulated in experiments with SARS-CoV-2 isolates [382-385], whereas another study with recombinant SARS-CoV-2 carrying the specific point mutations reported smaller effects on $\mathrm{nAb}$ titers against infectious SARS-CoV-2 [386]. E484K, N501Y, and K417N escape is alarming because of the dominance of class I and II nAbs among the vaccine- or natural infection-induced polyclonal $\mathrm{nAb}$ responses targeting the receptor-binding ridge of RBD including sites 417, 484, and 501 [378,387-389]. More recently, there was a massive outbreak of B.1.617 in India, a lineage characterized by the combination of L452R and E484Q spike mutations in sublineages B.1.617.1 and B.1.617.3 or L452R and T478K in B.1.617.2 [351,352,390]. Epidemiologic data and neutralization assays with pseudotyped viruses and isolates suggest a higher transmissibility and partly decreased sensitivity to nAbs and vaccines, which is primarily due to the effects of the RBD mutations E484Q and L452R [391-395]. B.1.617 variants are currently spreading globally, and are rapidly out-competing other variants [396]. 
Table 2. Amino acid replacements in global SARS-CoV-2 variants and their clinical impact.

\begin{tabular}{|c|c|c|c|c|c|c|c|c|c|c|c|}
\hline $\begin{array}{c}\text { Pangolin } \\
\text { Lineage }\end{array}$ & B.1.1.7 & B.1.351 & $\begin{array}{c}\text { P.1 } \\
\text { (B.1.1.248) }\end{array}$ & B.1.617 & $\begin{array}{c}\text { B.1.1.298 } \\
\text { (Cluster 5) }\end{array}$ & B.1.525 & B.1.160 & $\begin{array}{l}\text { B.1.427 } \\
\text { B.1.429 }\end{array}$ & B.1.2 & B.1.620 & B.1.526 \\
\hline $\begin{array}{c}\text { Variant } \\
\text { origin/first } \\
\text { detected }\end{array}$ & UK & South Africa & Brazil/Japan & India & $\begin{array}{l}\text { Denmark (from } \\
\text { minks) }\end{array}$ & Nigeria/UK & Europe & California & Midwest, USA & $\begin{array}{c}\text { Cameroon, } \\
\text { West-Central } \\
\text { Africa/Lithuania, } \\
\text { Europe }\end{array}$ & $\begin{array}{c}\text { New York, NY, } \\
\text { USA }\end{array}$ \\
\hline GISAID clade & GRY & GH & GR & G & GR & G & GH & GH & $\mathrm{GH}$ & G & $\mathrm{GH}$ \\
\hline VOC/VOI & VOC-20DEC-01 & VOC-20DEC-02 & VOC-21JAN-02 & $\begin{array}{c}\text { VOC-21APR-02 } \\
\text { (B.1.617.2) }\end{array}$ & - & $\begin{array}{c}\text { VOI } \\
\text { VUI-21FEB-03 }\end{array}$ & - & VOI & - & VOI & $\begin{array}{c}\text { under } \\
\text { monitoring- }\end{array}$ \\
\hline $\begin{array}{c}\text { WHO } \\
\text { (VOC/VOI) }\end{array}$ & Alpha & Beta & Gamma & $\begin{array}{c}\text { Delta } \\
\text { (B.1.617.2) }\end{array}$ & - & Eta & - & Epsilon & - & - & Iota \\
\hline $\begin{array}{c}\text { Other } \\
\text { names/Nextstrain }\end{array}$ & 20I/S:501Y.V1 & 20H/S:501Y.V2 & 20J/S:501Y.V3 & $\begin{array}{l}\text { G/452R.V3 } \\
\text { 21A/S:478K }\end{array}$ & $\begin{array}{l}\Delta \text { FVI-Spike } \\
20 \mathrm{~B}\end{array}$ & $\begin{array}{c}\text { UK1188 } \\
\text { 20A/S:484K }\end{array}$ & 20A.EU2- & $\begin{array}{l}\text { CAL.20C20C } \\
\text { /S:452R }\end{array}$ & COH.20G.Q677H & $20 \mathrm{~A}$ & $\begin{array}{c}20 \mathrm{C} \\
20 \mathrm{C} / \mathrm{S}: 484 \mathrm{~K}\end{array}$ \\
\hline Clinical impact & $\begin{array}{l}\text { Epidemiological } \\
\text { data suggest } \\
\text { increased } \\
\text { transmissibility } \\
\text { and virulence; } \\
\text { Little impact on } \\
\text { vaccine efficacy }\end{array}$ & $\begin{array}{c}\text { Suggested } \\
\text { increased } \\
\text { transmissibility } \\
\text { but no influence } \\
\text { on virulence; } \\
\text { In vitro studies } \\
\text { suggest partial } \\
\text { nAb immune } \\
\text { escape and } \\
\text { reduced vaccine } \\
\text { efficacy }\end{array}$ & $\begin{array}{c}\text { Effect on } \\
\text { transmissibility } \\
\text { and virulence } \\
\text { under } \\
\text { investigation; } \\
\text { In vitro studies } \\
\text { suggest partial } \\
\text { nAb immune } \\
\text { escape and } \\
\text { reduced vaccine } \\
\text { efficacy }\end{array}$ & $\begin{array}{l}\text { Epidemiological } \\
\text { data suggest } \\
\text { increased } \\
\text { transmissibility; } \\
\text { In vitro studies } \\
\text { suggest partial } \\
\text { nAb immune } \\
\text { escape and } \\
\text { reduced vaccine } \\
\text { efficacy }\end{array}$ & $\begin{array}{c}\text { Suggested } \\
\text { increased } \\
\text { transmissibility; } \\
\text { no evidence of } \\
\text { increased } \\
\text { virulence or } \\
\text { vaccine immune } \\
\text { evasion }\end{array}$ & $\begin{array}{l}\text { Suggested to } \\
\text { have partial } \\
\text { nAb immune } \\
\text { escape and } \\
\text { reduced vaccine } \\
\text { efficacy }\end{array}$ & $\begin{array}{l}\text { No evidence of } \\
\text { increased } \\
\text { transmissibility, } \\
\text { virulence, or } \\
\text { immune evasion }\end{array}$ & $\begin{array}{c}\text { Epidemiological } \\
\text { data suggest } \\
\text { increased } \\
\text { transmissibility; } \\
\text { In vivo and } \\
\text { pseudovirus } \\
\text { data suggest } \\
\text { increased } \\
\text { virulence and } \\
\text { partial immune } \\
\text { evasion }\end{array}$ & $\begin{array}{l}\text { No evidence of } \\
\text { increased } \\
\text { transmissibility, } \\
\text { virulence, or } \\
\text { immune evasion }\end{array}$ & $\begin{array}{l}\text { Suggested to } \\
\text { have partial } \\
\text { nAb immune } \\
\text { escape and } \\
\text { reduced vaccine } \\
\text { efficacy }\end{array}$ & $\begin{array}{c}\text { Suggested to } \\
\text { have increased } \\
\text { transmissibility; } \\
\text { no evidence of } \\
\text { increased } \\
\text { virulence yet; } \\
\text { partial nAb } \\
\text { immune escape } \\
\text { and reduced } \\
\text { vaccine efficacy } \\
\text { predicted }\end{array}$ \\
\hline \multicolumn{12}{|c|}{ Amino acid mutations and deletions } \\
\hline NSP1 & - & - & - & - & $\Delta \mathrm{M} 85$ & - & - & - & - & - & - \\
\hline NSP2 & - & T85I & - & - & - & - & - & T85I ${ }^{\#}$ & T85I & T223I & T85I \\
\hline NSP3 (PL-pro) & $\begin{array}{l}\text { T183I, A890D, } \\
\text { I1412T }\end{array}$ & $\mathrm{K} 837 \mathrm{~N}$ & S370L, K977Q & - & $\Delta \mathrm{N} 1264$ & T1189I & - & - & M1788I & V1173I & - \\
\hline NSP4 & - & H36Y, S137L & - & - & - & - & M324I & - & - & - & L438P \\
\hline NSP5 (3CL-pro) & - & K90R & - & - & - & - & - & - & L89F & - & - \\
\hline NSP6 & $\begin{array}{l}\Delta \text { S106-G107- } \\
\text { F108 }\end{array}$ & - & $\begin{array}{l}\Delta \text { S106-G107- } \\
\text { F108 }\end{array}$ & - & - & $\begin{array}{l}\Delta \text { S106-G107- } \\
\text { F108 }\end{array}$ & - & - & - & $\begin{array}{l}\Delta \text { S106-G107- } \\
\text { F108 }\end{array}$ & $\begin{array}{l}\Delta \text { S106-G107- } \\
\text { F108 }\end{array}$ \\
\hline NSP9 & - & - & - & - & - & - & - & $\mathrm{I} 65 \mathrm{~V}^{\#}$ & - & - & - \\
\hline NSP12 (RdRp) & P323L & D144Y, P323L & P323L & P323L & P323L, T739I & P323F* & $\begin{array}{l}\text { A185S, P323L, } \\
\text { V776L }\end{array}$ & P323L & P323L & P323L & P323L \\
\hline $\begin{array}{c}\text { NSP13 } \\
\text { (Helicase) }\end{array}$ & - & T588I & E341D & $\begin{array}{l}\text { P77L }{ }^{\#} \\
\text { M429I }\end{array}$ & - & - & K218R, E261D & $\begin{array}{l}\text { P53L }^{\#}, \\
\text { D260Y }\end{array}$ & - & A292S & Q88H \\
\hline NSP14 & - & - & - & - & - & - & - & - & N129D & - & - \\
\hline NSP15 & - & - & - & K259R\# & T112I & - & - & - & - & - & - \\
\hline
\end{tabular}


Table 2. Cont.

\begin{tabular}{|c|c|c|c|c|c|c|c|c|c|c|c|}
\hline $\begin{array}{l}\text { Pangolin } \\
\text { Lineage }\end{array}$ & B.1.1.7 & B.1.351 & $\begin{array}{c}\text { P.1 } \\
\text { (B.1.1.248) } \\
\end{array}$ & B.1.617 & $\begin{array}{c}\text { B.1.1.298 } \\
\text { (Cluster 5) }\end{array}$ & B.1.525 & B.1.160 & $\begin{array}{l}\text { B.1.427 } \\
\text { B.1.429 } \\
\end{array}$ & B.1.2 & B.1.620 & B.1.526 \\
\hline NSP16 & - & - & - & - & - & - & - & - & R216C & - & - \\
\hline Spike & $\begin{array}{c}\Delta \mathrm{H} 699-\mathrm{V} 70, \\
\Delta \mathrm{Y144}, \mathrm{N} 501 \mathrm{Y} \\
\text { A570D, D614G, } \\
\text { P681H, T716I } \\
\text { S982A, D1118H }\end{array}$ & $\begin{array}{c}\text { L18F, D80A } \\
\text { D215G, } \Delta \text { L241- } \\
\text { L242-A243, } \\
\text { R246I, K417N * } \\
\text { E484K, N501Y } \\
\text { D614G, A701V }\end{array}$ & $\begin{array}{l}\text { L18F, T20N, } \\
\text { P26S, D138Y, } \\
\text { R190S, K417T *', } \\
\text { E484K, N501Y, } \\
\text { D614G, H655Y, } \\
\text { T1027I, V1176F }\end{array}$ & $\begin{array}{c}\text { G142D }^{\#}, \\
\text { E154K\#, L452R, } \\
\text { T478K } \mathrm{K}^{\#,} \\
\text { E484Q }{ }^{\# *}, \\
\text { D614G, P681R }\end{array}$ & $\begin{array}{c}\Delta \mathrm{H} 69-\mathrm{V} 70 \\
\text { Y453F, D614G } \\
\text { I692V, M1229I }\end{array}$ & $\begin{array}{c}\text { Q52R, A67V, } \\
\Delta \mathrm{H} 69-\mathrm{V} 70, \\
\Delta \mathrm{Y144}, \mathrm{E} 484 \mathrm{~K} \\
\mathrm{D} 614 \mathrm{G}, \mathrm{Q677H} \\
\text { F888L }\end{array}$ & S477N, D614G & $\begin{array}{l}\text { S13I, W152C, } \\
\text { L452R, D614G }\end{array}$ & D614G, Q677H & $\begin{array}{c}\text { P26S, } \\
\Delta \mathrm{H} 69-\mathrm{V} 70, \\
\text { V126A, } \Delta \text { Y144, } \\
\Delta \mathrm{L} 241-\mathrm{L242-} \\
\text { A243, H245Y, } \\
\text { S477N, E484K, } \\
\text { D614G, P681H, } \\
\text { T1027I, D1118H }\end{array}$ & 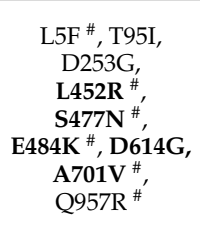 \\
\hline M & - & - & - & I82T/S \# & - & I82T & - & - & A85S & - & - \\
\hline ORF7a & - & - & - & V82A & - & - & - & - & - & - & - \\
\hline ORF8 & $\begin{array}{l}\text { Q27stop, R52I, } \\
\text { Y73C }\end{array}$ & - & E92K & - & - & - & - & - & S24L & - & T11I \\
\hline ORF9b & - & - & - & - & - & - & - & - & - & I5T & - \\
\hline E & - & P71L & - & - & - & L21F & - & - & - & & - \\
\hline $\mathbf{N}$ & $\begin{array}{l}\text { D3L, R203K, } \\
\text { G204R, S235F }\end{array}$ & T205I & $\begin{array}{c}\text { P80R, R203K, } \\
\text { G204R }\end{array}$ & R203M * D377Y & $\begin{array}{c}\text { S194L, R203K, } \\
\text { G204R }\end{array}$ & A12G, T205I & M234I, A376T & T205I & $\begin{array}{l}\text { P67S, P199L, } \\
\text { D377Y }\end{array}$ & A220V & P199L ${ }^{\#}$, M234I ${ }^{\#}$ \\
\hline
\end{tabular}

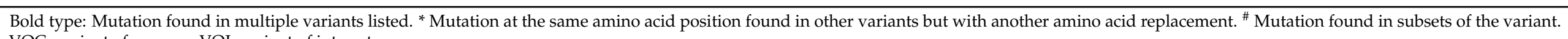
VOC: variant of concern; VOI: variant of interest. 
To date (mid-2021), B.1.351 and P.1 are the most resistant variants to anti-SARS-CoV-2 $\mathrm{nAb}$ responses, and notably, they also acquired the ability to use ACE from other species, thus extending the host range to mice and minks [397,398]. As shown for P.1 variants in Brazil, VOCs may also facilitate coinfections with different SARS-CoV-2 lineages [399]. While animal experiments and human vaccine data suggest that vaccines still provide sufficient protection of disease after challenge with B.1.1.7 or B.1.351 variants [364,400-402], a clinical trial in South Africa showed that vaccine efficacy of an approved adenovirus vaccine dropped from $>70 \%$ to $\sim 10 \%$ in preventing mild or moderate disease [403]. Preliminary data indicate that natural infection with B.1.351 as well as immunizations with mutant antigens induce cross-neutralizing $\mathrm{Ab}$ responses including potent neutralization of mutant viruses such as B.1.351, indicating that targeted booster vaccines might be broadly effective [404-406].

In addition to the four VOCs mentioned above, several more variants have emerged with transient peaks or an ongoing rise in regional or supra-regional prevalence [31,407-409]. In late 2020 and early 2021, multiple emerging variants were reported in South Africa in addition to VOC B.1.351, and a novel variant was identified in Nigeria carrying the $\mathrm{P} 681 \mathrm{H}$ mutation, known from B.1.1.7 [410,411]. In Europe, Cluster 5 variants emerged following an outbreak of mink infections with supposed human spill-over in Denmark [412]. Cluster 5 variants have a prominent $\Delta 69-70$ deletion in spike NTD that became dominant later in the B.1.1.7 lineage. $\Delta 69-70$ is a prime example of deletions that occur in the SARS-CoV-2 genome, which may drive adaptive evolution and facilitate antibody escape through compensatory mechansisms [413]. Deletions occur during genome replication due to strand slippage and cannot be corrected by the polymerase's proof-reading mechanism, and thus represent an evolutionary mechanism of generating altered viral genomes despite the low inherent base substitution rate of SARS-CoV-2 [414]. The cluster 5 variant's Y453F mutation in RBD can reduce titers of therapeutic nAbs in in vitro pseudovirus assays [415,416], but has limited impact on the polyclonal $\mathrm{nAb}$ response in vaccines [343]. Furthermore, variants 20A.EU1 (B.1.177) and 20A.EU2 (B.1.160) increased in dominance, the latter one carrying the $\mathrm{S} 477 \mathrm{~N}$ mutation in RBD that might have resulted from selective pressure exerted by the host $\mathrm{nAb}$ response and possibly increases RBD's affinity for ACE2 [371,417]. In the US, two Californian lineages (B.1.427 and B.1.429) gained dominance in the second year of the pandemic, characterized, again, by recurring spike mutations [418]. Epidemiological data suggest a $\sim 20 \%$ increased transmissibility, and in vivo and in vitro data suggest increased shedding, increased infectivity, and a modest decrease in neutralizing titers from convalescent patients and vaccine recipients, mediated by L452R [419,420]. In the Midwest of the USA, variants with diverse mutations at amino acid position N677 increased in frequency, which, due to N677's proximity to the polybasic S1/S2 cleavage site, potentially affect functional features including viral entry, transmission, and/or spread [421,422]. In New York, B.1.526 variants were detected frequently carrying either the S477N or E484K mutation (Table 2, Figure 6) [423,424]. Since E484K is known to impair nAb efficacy as described for B.1.351 and P.1, these variants pose a possible bias to vaccines.

More recently, lineage B.1.525 was detected in the UK and in Nigeria and rapidly spread over more than 20 countries in the world. It is characterized by the combination of key mutations of different variants, namely E484K, $\triangle \mathrm{H} 69-\mathrm{V} 70, \mathrm{~N} 439 \mathrm{~K}$, and Y453F, and inclusion of a new F888L mutation in the spike S2 domain [425]. B.1.620, first identified in Lithuania, Europe, is spreading in different European countries and traces back to its probable origin Cameroon and surrounding West-Central African countries [426]. Notably, it contains a combination of spike mutations and deletions from different VOCs, including E484K, S477N, P681H, $\triangle \mathrm{H} 69-\mathrm{V} 70$, and $\triangle \mathrm{Y} 144 \mathrm{D}$. In Uganda, the A23.1 variant was detected that lacks D614G, but acquired P681R and the RBD mutation V367F [427]. On the Philippines, variant P.3 was identified, which stems from the same lineage B.1.1.28 as P.1 and harbors N501Y, E484K, and P681H mutations [428]. In Peru and Chile, a new sublineage within B.1.1.1 is expanding, designated C.37, with the novel spike deletion $\Delta 246-252$ [429]. Additionally, Vietnam has experienced a spike in COVID-19 cases and detected a hybrid 
variant with features of both the B.1.1.7 (UK) and B.1.617.2 (Indian) variants, which likely rendered the virus more transmissible [430].

There is growing evidence that similar combinations of mutations evolve across the globe with overlap to mutations determined in in vitro selection experiments. They include mutations at spike position 484, 501, and 614 as well as deletions in NTD (Table 2, Figure 6). It implies that SARS-CoV-2 variants are converging based on common purifying selection processes. The associated appearance of mutations, e.g., in the VOCs at spike positions 417, 484, 501, and 681 indicate the importance of synergisms and compensatory mutations to fine-tune neutralization escape, infectivity, and replicative fitness [125,380]. Close monitoring of variants will remain crucial to identify emerging $\mathrm{nAb}$ escape variants and discern phylodynamic spread based on immune pressure from founder effects and sampling bias. Surveillance of mutations, recombination, and novel genome architectures within spike as well as the full genome is required to reassess the efficacy of vaccines for the mitigation of SARS-CoV-2 spread [431-435].

\section{Cellular Responses}

The cellular immune responses triggered by either SARS-CoV-2 or HIV-1 represent a double-edged sword in determining disease outcomes. While early cellular immune responses primarily have a protective role, deregulated and exacerbated inflammatory responses can prevent viral clearance and worsen disease outcomes [58,436]. Furthermore, in the context of COVID-19, the transition between innate and adaptive immune responses plays a key role in viral clearance and lung pathology. The accumulation of proinflammatory cytokines, lymphopenia, deviant $\mathrm{T}$ cell responses, and antiviral immunity mediated by the generation of nAbs in COVID-19 patients suggest that SARS-CoV-2 might induce an immune-related disease [437-439]. Indeed, SARS-CoV-2-infected individuals exhibit cellular and humoral immune responses, which characterize mild from severe cases. Individuals with asymptomatic or mild disease mount a predominant cellular but low to no humoral immune response, but patients with severe disease mount a potent humoral but moderate cellular immune response [440]. Similarly, the involvement of host cellular immunity in HIV-1 infection is central to the progression of AIDS [58,441]. Due to the infection and subsequent depletion of $\mathrm{CD}^{+} \mathrm{T}$ cells and macrophages, HIV-1 exerts direct and indirect effects on the cellular immune pool.

\subsection{T Cells}

A functional $\mathrm{T}$ cell immune response is typically highly effective at eliminating viral infections and/or suppressing viral replication. In turn, dysfunctional responses are associated with severe/progressive disease, as is the case for SARS-CoV-2 and HIV-1 infections. Furthermore, the lymphocyte count is an important clinical parameter of both SARS-CoV-2 and HIV-1 infections as lymphopenia is a common feature in severe/progressive infections of each virus. However, the processes leading to lymphopenia during the two infections are very different. Mild courses of SARS-CoV-2 infection in individuals with agammaglobulinemia, characterized by a lack of B cells, showed that Abs are not the only important variable to clear or control infection [442]. Compared to humoral immunity, $\mathrm{T}$ cell responses target a broader range of viral antigens beyond spike/Env, including strong responses against HIV-1 Gag, Pol, and Nef, or SARS-CoV-2 M, N, and ORF3a [443-445]. They further possess a larger breadth, e.g., recognizing at least $30-40 \mathrm{CD} 4^{+} \mathrm{T}$ cell epitopes in each donor with minimal overlap with Ab epitopes [446].

The coordination between the innate and the adaptive immune responses in the early stages of SARS-CoV-2 infection is essential to control viral spread [447]. Indeed, delayed or insufficient activation of $\mathrm{T}$ cell responses may lead to severe lung damage or systemic inflammation, whereas early induction of functional SARS-CoV-2-specific T cells is associated with rapid viral clearance and mild disease in COVID-19 patients [448-450]. In agreement with analyses in the blood, functional and consistent $\mathrm{CD} 8^{+}$resident-memory (TRM) and $\mathrm{CD}^{+}{ }^{+}$T-helper-17 (TH17) cells in bronchoalveolar lavages were associated 
with beneficial outcomes $[451,452]$. Both $\mathrm{CD}^{+}$and $\mathrm{CD}^{+} \mathrm{T}$ cell responses to SARS-CoV-2 have been determined as important parameters associated with control of SARS-CoV2 infection, yet $\mathrm{CD}^{+} \mathrm{T}$ cell responses appear even more prominent than $\mathrm{CD}^{+} \mathrm{T}$ cell responses [221,443,444,453]. Although T cell responses can be slightly elevated in severe COVID-19 cases [444], the activation of helper T (Th) and cytotoxic T cells (CTLs) by SARSCoV-2 may be either beneficial or harmful depending on whether potent or exhausted immune responses are mounted [436].

The levels of $\mathrm{T}$ cells and their elicited responses fluctuate during infection of both SARS-CoV-2 and HIV-1, and often distinguish severe/progressive from mild/controlled infections. In patients with severe or fatal COVID-19, the total lymphocyte count is reduced compared with non-severe patients [454,455], which could be a predictive marker for disease severity [454,456]. Moreover, functional T cells were elevated in patients with mild COVID-19 expressing higher levels of cytotoxic molecules such as granzyme A and Fas ligand that were beneficial in eliminating virus-infected cells. These molecules were reduced in severe disease cases due to the compacted CTL proportion [457]. Thus, SARSCoV-2-specific $\mathrm{T}$ cell numbers correlated with less severe COVID-19 in a prospective study [458]. SARS-CoV-2-specific $\mathrm{CD}^{+}$and $\mathrm{CD}^{+} \mathrm{T}$ cells are found in peripheral blood from COVID-19 patients in the first two weeks after symptom onset, and the majority of these $\mathrm{CD}^{+} \mathrm{T}$ cells exhibit a central memory phenotype with a dominant production of Th1 cytokines, while CD8 ${ }^{+} \mathrm{T}$ cells have a more effector phenotype with high levels of perforin expression [459]. Although lymphopenia preferentially affects CD8 ${ }^{+} \mathrm{T}$ cells $[460,461]$, both $\mathrm{CD}^{+}$and $\mathrm{CD}^{+} \mathrm{T}$ cell levels were reduced in number and frequency but exhibited increased activation in COVID-19 patients [69,461,462]. This activation state can mount potent immune responses or generate functional exhaustion. At the convalescent stage, SARS-CoV-2-specific T cells generate broad and polyfunctional responses and they even occur after mild infection or in seronegative individuals [444,463].

In the early stages of HIV-1 infection, the virus is able to undermine the T cell immune response by infecting $\mathrm{CD}^{+} \mathrm{T}$ cells, thus reducing their numbers and impairing their function, which ultimately contributes to viral immune escape [58]. Nevertheless, HIV-1specific CTLs are crucial to lower the massive viral burden in the early days and weeks of infection to reach the (predictive) viral set point [445]. Indeed, the T cell response is understood to be responsible for the successful and persistent control of HIV-1 viral titers in long-term nonprogressors (LNTPs) or elite controllers (ECs) [58,464-466]. CD4 ${ }^{+}$T cell responses including regulatory $\mathrm{T}$ cells (Tregs) and Tfh cells are known to play an important role in HIV-1 pathogenesis [467] but also vaccine outcome [220,468]. In a large HIV-1 vaccine trial (RV144), functional CD4 ${ }^{+} \mathrm{T}$ cell responses have been associated with reduced risk of infection. Specifically, levels of Env-specific poly-functional CD4 ${ }^{+}$effector memory T cells capable of secreting multiple cytokines including CD40L, IL-2, IL-4, IFN- $\gamma$, and TNF- $\alpha$ were associated with higher vaccine efficacy $[220,468]$.

The Time Course of T Cell Responses in SARS-CoV-2 and HIV-1 Infection

In HIV-1 infection, the $\mathrm{T}$ cell response initially rises following the increase in viral load and peaks as the viral load begins to drop (Figure 5a) [469-472]. In progressive HIV-1 infections, the viral load may again increase while the $\mathrm{T}$ cell response inversely decreases, which is partly due to T cell exhaustion in these cases (Figure 5a) [471,473]. Additionally, the effective T cell control of HIV-1 is also heavily reliant on HLA presentation of peptides to $\mathrm{CD}^{+} \mathrm{T}$ cells. The HLA alleles HLA-B27 and HLA-B57, as well as a polymorphism in HLA-C, have been identified in LTNP/EC individuals and are suggested to stimulate more effective $\mathrm{CD}^{+}$immune responses than those observed in cases of progressive HIV-1 infection [474]. HIV-1-infected LTNP/EC individuals also maintain poly-functional CD8 ${ }^{+}$ responses with enhanced degranulation, cytokine, and chemokine production, contributing to a controlled infection in these individuals (Figure 5a) [475-477]. In terms of the CD4 ${ }^{+}$ T cells, as primary targets of HIV-1, their levels are low during peak viremia, typically 21-28 days p.i., but return to normal levels in the following weeks during the establishment of the viral set point [64]. Of note, the $\mathrm{CD}^{+} \mathrm{T}$ cell levels have been observed to return to 
normal within the blood but not within the gastrointestinal tract, which represents a major site of T cell depletion due to HIV-1-induced apoptosis, causing an overall reduction in $\mathrm{CD}^{+} \mathrm{T}$ cells during chronic HIV-1 infection (Figure 5a) [478-480].

A longitudinal study of $\mathrm{CD}^{+} \mathrm{T}$ cells during SARS-CoV-2 infections revealed an exhausted phenotype of $\mathrm{CD}^{+} \mathrm{T}$ cells, based on the presence of exhaustion markers including PD-1, CTLA-4, and TIGIT, which, together with reduced poly-functionality according to markers such as IFN- $\gamma, \mathrm{TNF}-\alpha$, and IL-2, predicted disease severity [481]. However, other studies showed that $\mathrm{CD}^{+} \mathrm{T}$ cells are not exhausted but remain functional $[482,483]$ and a significant proportion of SARS-CoV-2-reactive T cells with "exhausted" phenotype are also found in patients with mild COVID-19 [484]. Interestingly, these cells exhibited lesser cytotoxic and inflammatory features and could maintain their exhausted state even after viral clearance. In contrast, SARS-CoV-2-reactive $\mathrm{CD}^{+} \mathrm{T}$ cells from patients with severe disease displayed multiple features that support the generation of robust $\mathrm{CD}^{+} \mathrm{T}$ cell memory responses with pro-survival properties and a lack of restraining exhaustion features [484]. To what degree SARS-CoV-2 causes T cell exhaustion and/or impaired $\mathrm{T}$ cell memory remains to be determined. Nevertheless, the high durability of $\mathrm{T}$ cell responses suggests that $\mathrm{T}$ cells are a critical component among the correlates of protection after infection or vaccination [485]. The potency and breadth of anti-SARS-CoV-2 T cell responses, which are readily induced post natural infection and vaccination, may drive humoral responses and/or compensate the lack of sufficient $\mathrm{nAb}$ responses in the early weeks post vaccination when neutralization is still weak [239]. Of note, the vast majority of SARS-CoV-2 T cell epitopes are not affected by the mutations found in circulating mutant variants [486]. In summary, depending on the magnitude and functionality of the highly specific $\mathrm{T}$ cell responses, they can either drive protective or pathogenic immune responses in SARS-CoV-2 infection.

\subsection{B Cells}

B cell responses in SARS-CoV-2 infection occur concomitantly with T follicular helper (Tfh) responses, starting approximately one week after symptom onset [487]. Antigenspecific $\mathrm{CD}^{+} \mathrm{T}$ cells are important for eliciting potent $\mathrm{B}$ cell responses that result in $\mathrm{Ab}$ affinity maturation, and spike-specific $\mathrm{T}$ cell levels correlate with serum IgG and IgA titers [443]. Memory B cells (Bmem), circulating Tfh cells, and spike-specific Abs are positively associated with plasma neutralizing activity in patients who have recovered from COVID-19 [488]. The SARS-CoV-2-specific B cell repertoire consists of transcriptionally distinct $\mathrm{B}$ cell populations with two main clusters of potent $\mathrm{nAb}$-producing cells, resembling memory and activated B cells [489].

In addition to antibody production, B cells establish immunological memory, the basis for durable protective immunity after infection or vaccination. Duration of immunological memory after SARS-CoV-2 infection and COVID-19 is still unclear, but antigen-specific memory $\mathrm{T}$ and $\mathrm{B}$ cells are detectable in convalescence $[488,490]$ and each component of immune memory appears to exhibit distinct kinetics [244]. There is growing evidence that SARS-CoV-2 infection generates antigen-driven long-lasting B cell memory that persists and matures for several months after SARS-CoV-2 infection and may provide long-term protection against systemic disease upon reinfection [491,492]. A recent study confirmed that SARS-CoV-2 infection induces long-lived bone marrow plasma cells [493]. Thus, waning $\mathrm{nAb}$ titers in plasma several months post infection may be compensated by the persistent Bmem repertoire that remains at constant levels or can even increase [494]. Further studies are required to elucidate the contribution and protective capacity of Bmem cells in SARS-CoV-2 infection.

In terms of HIV-1 infection, the B cell response is highly dysregulated, resulting in patient hypergammaglobulinemia and defective humoral responses $[495,496]$. The dysregulation of the $\mathrm{B}$ cell responses, specifically polyclonal B cell activation, was one of the first immunological abnormalities identified in HIV-1-infected individuals [497]. This HIV-1-induced dysregulation was later determined to be driven by active HIV-1 replication 
and coincides with the increase in viral titers (Figure 5a). The normalization of B cell responses in HIV-1 viremic individuals following antiretroviral treatment (ART) suggested the HIV-1-specific B cell responses to be driven by HIV-1 replication [498,499]. Indeed, the abnormal B cell responses, including non-specific polyclonal Ab responses and hypergammaglobulinemia, are now considered hallmarks of active HIV-1 replication [500-502]. The ability of HIV-1 to dysregulate the B cell response is proposed to be a consequence of the virus's depletion of $\mathrm{CD}^{+}$cells [496]. In particular, the Tfh cells, which are crucial for $\mathrm{B}$ cell maturation and the generation of the $\mathrm{Ab}$ response, were found to be functionally impaired in HIV-1-infected individuals and unable to aid B cell function adequately [503]. Moreover, early HIV-1 replication has been shown to cause mass apoptosis of primary infected cells and bystander cells through the production of apoptotic microparticles and the secretion/shedding of apoptosis-inducing HIV-1 viral proteins [504]. This considerable apoptotic activity combined with the high levels of HIV-1 replication within the lymph nodes likely contributes to the damage or loss of approximately $50 \%$ of germinal centers observed within the first 80 days of HIV-1 infection [505,506]. As major sites of B cell function and the generation of HIV-1 nAbs [507], the HIV-1-induced destruction of germinal centers considerably impairs the infected individual's ability to rapidly generate high-affinity HIV-1 Abs [64]. In addition to the early impairment of B cell maturation and Ab generation, HIV-1 infection has also been demonstrated to compromise the proliferation and cytokine secretion of memory/activated B cells [508,509]. Altogether, it is apparent HIV-1 imposes considerable restrictions on B cell functions early during infection, impairing the host's ability to mount an effective humoral immune response. Conversely, LTNP/EC HIV-1-infected individuals maintain an effective B cell response, notably that of Tfh cell function [510], which contributes to their control of the infection and offers important considerations for effective vaccine design.

\subsection{Monocytes/Macrophages}

Pathogenic changes in the monocytic compartment regarding phenotypes and function and an increase in immature neutrophils are central hallmarks of COVID-19 [511]. Macrophage activity drives both inflammation and much of the pathology in COVID-19 patients [512,513]. These cells act as sentinels to limit early viral replication by initiating an IFN-I response and an inflammatory response to recruit additional immune cells [514]. However, when macrophages are highly activated, these cells can produce large amounts of cytokines (cytokine storm) that generate systemic hyperinflammation [515]. Megakaryocytes and monocyte subsets are critical peripheral sources of cytokine storms, which involves interactions of hyper-inflammatory cell subtypes in lung and peripheral blood [169]. The activation of macrophages is called macrophage activation syndrome (MAS) [515], and MAS-like severe inflammation and fibrinolysis are involved in COVID-19-associated pneumonia [516,517]. In lungs of COVID-19 patients, moderate levels of macrophages can be found in alveolar exudates while infiltrated $\mathrm{T}$ cells and monocytes are found in the interstitial compartment [518], and infiltrated macrophages in the alveolar lamina [519].

In the lungs, different macrophage populations exist that diverge in their gene expression profile and tissue localization [520]. In COVID-19 patients, anti-inflammatory monocyte-derived (FCN1 ${ }^{\text {high }}$ ) macrophages were identified in patients with mild disease, while resident pro-fibrotic (SPP1 ${ }^{\text {high }}$ ) and inflammatory alveolar macrophages (FAPB4 ${ }^{+}$) dominated in patients with severe disease [457]. Additionally, increased cellular interactions were found in patients with critical COVID-19, and they were consistent with a higher activation status of non-resident macrophages, monocyte-derived macrophages, and CTL. In particular, non-resident macrophages showed a highly inflammatory profile characterized by significantly higher expression levels of chemokine encoding genes (CCL2, CCL3, CCL20, and CXCL1) and pro-inflammatory cytokines (IL8, IL18, and TNF) in patients with critical disease [521].

ACE2 expression on macrophages is limited to $\mathrm{CD} 169^{+}$macrophages in lymph nodes and spleen, which renders these macrophages susceptible to SARS-CoV-2 infection [512]. 
Despite the lack of ACE2 expression, other studies suggested that SARS-CoV-2 can also infect alveolar macrophages, establishing a positive feedback with $\mathrm{T}$ cells that drive persistent alveolar inflammation [522]. Infection of macrophages by other coronaviruses is known to induce altered functional states, e.g., impaired MHC II presentation by MERS$\mathrm{CoV}[523,524]$. Although the mechanism is not fully understood, MHC II downregulation was also demonstrated in monocytes and B cells from COVID-19 patients and its expression was partially restored by using an inhibitor targeting IL-6, a major driver of COVID-19 pathology [525]. Altogether, current knowledge suggests that macrophage polarization and the composition of macrophage subpopulations play key roles in COVID-19 severity.

Similar to SARS-CoV-2 infection, the monocytes and subsequently macrophages drive much of the inflammation associated with HIV-1 infection [526], but in this case, also constitute important reservoirs and disseminators of HIV-1 [527-529]. Circulating monocytes are some of the first cells to respond to HIV-1 infection and are key mediators of host antiviral defenses and inflammation [528]. Importantly, CD16 ${ }^{+}$and intermediate monocytes, which express the HIV-1 co-receptor CCR5, can be infected by HIV-1 [530]. Furthermore, HIV-1 is able to replicate within these monocytes, generating reservoirs of the replication-competent latent provirus [531,532]. This combined with their ability to participate in cell-to-cell transmission of HIV-1 [533], instigates CD16 ${ }^{+}$monocytes as key disseminators of HIV-1. Moreover, their ability to cross the blood-brain barrier further instigates these monocytes as the primary source of HIV-1 infection in the brain and subsequently key perpetrators of the development of HIV-1-associated neurocognitive disorders [534]. Importantly, HIV-1 has been demonstrated to persist in monocyte-derived tissue-resident macrophage during antiretroviral therapy $[535,536]$, which emphasizes the necessity of including these cells in latency-reversing anti-HIV-1 therapies.

\section{Cytokines and Innate Immune Response}

The host innate immune response is initiated through the recognition of viral components or products of the viral replication cycle by pattern recognition receptors (PRRs). For viruses with an RNA genome such as HIV-1 and SARS-CoV-2, this occurs through three main classes of PRRs: Toll-like receptors, RIG-I-like receptors (RLRs), and NODlike receptors (NLRs) [537]. However, unlike SARS-CoV-2, HIV-1 may also be detected by multiple DNA receptors, including cGAS, IFI6, and DDX41, due to its unique DNA replication intermediate [65]. Moreover, host adaptor proteins PQBP1 and NONO have been demonstrated to selectively aid in the detection of these transient retroviral DNA replication intermediates [538,539].

Central to the innate immune response is the production of multiple cytokines with various immunomodulatory effects required to control viral infection. For both SARS-CoV2 and HIV-1, the magnitude and duration of the innate immune response are key determinants of either severe/progressive or mild/controlled infection. During mild/controlled SARS-CoV-2 and HIV-1 infections, the innate immune response, which is primarily determined by cytokine production, is initially robust, controls the viral levels, and then quickly subsides (Figure 5, purple and blue curves). Conversely, in severe/progressive infections of these viruses, the cytokine production is typically delayed but then exhibits an enhanced magnitude and prolonged duration, compared to mild/controlled cases (Figure 5, purple lines). This phenomenon is commonly referred to as 'cytokine storm'. The prolonged innate immune response coincides with sustained viral levels (Figure 5, blue curves). Consequently, SARS-CoV-2 and HIV-1 severe/progressive cases fail to control viral replication and exhibit an exuberant cytokine production, which hence develop aggravated clinical symptoms (Figure 5, red curves).

The production of pro- and anti-inflammatory circulating cytokines drives much of the disease pathophysiology associated with SARS-CoV-2 and HIV-1 infections and offers insight into the stage of infection and disease outcome. COVID-19 pathogenesis can be divided into two phases: the early phase, where the viral infection affects the upper respiratory tract (1-14 days of initial encounter), and the late phase, when the virus spreads 
to the lungs and induces profound hypoxemia and respiratory failure accompanied by other complications such as viral sepsis, different organ failures, and death. Although most SARS-CoV-2 infections are asymptomatic or mildly symptomatic [540], in a minority of cases, the virus can cause severe pneumonia and in some of them develop into acute respiratory distress syndrome (ARDS) and systemic disease [541] (Figure 5b). The outcome of SARS-CoV-2 infections depends on both the viral load and the immune responses [542]. Likewise, HIV-1 infection can be separated into two main stages; the early acute infection spanning the first few months from the initial transmission and the subsequent chronic infection, which is currently incurable and consequently lifelong. Both stages have distinct viral features and clinical symptoms. The early stages of HIV-1 infection from the time of transmission, can be sequentially divided into the eclipse period where viral RNA remains undetectable in plasma, peak viremia, and the viral set point which exhibits stable viremia [64]. During this time, patients generally only experience common cold-like symptoms. Conversely, during the chronic stage of HIV-1 infection, where virus levels fluctuate due to reanimated latent reservoirs and immune escape mutants, untreated individuals exhibit substantial immune suppression contributing to HIV-1-associated diseases and the development of AIDS (Figure 5a).

Among the heavily distorted innate immune response typical of COVID-19, the late-wave inflammatory response in particular is linked to COVID-19 disease severity [483,543-545]. The major differences in immune phenotype between moderate and severe cases are apparent after day 10 of infection. These can be grouped into two main clusters: (1) patients with decreased expression of pro-inflammatory cytokines and enrichment of tissue repair genes for whom the disease trajectory remains moderate, leading to eventual recovery; and (2) patients with higher and sustained pro-inflammatory cytokine levels who exhibit a worse disease trajectory, which can lead to death [69]. Signature cytokines in severe COVID-19 include enhanced expression of IL-6, IL-1 $\beta$, IL-1 $\alpha$, IL-2, IL-7, IL-10, TNF $\alpha$, MIP1 $\alpha$, MCP1, G-CSF, IFN $\gamma[69,73,521,546-548]$. In children, the increased inflammatory markers include IL-6, IL-1, and C-reactive protein along with procalcitonin in serum [549]. Among all the above-mentioned cytokines, IL- 6 has been reported as a major driver of COVID-19 pathophysiology. Consistent with this, the highest IL-6 levels were observed in patients requiring intensive care. In these patients, there is a continuous IL-6 increase over time and levels are elevated in non-survivors [550,551]. In addition, secretory cells from COVID-19 patients show higher expression of the chemokine-ligand encoding genes CXCL1, CXCL2, CXCL3, CXCL6, CXCL8, CXCL16, and CXCL17, likely promoting the recruitment of neutrophils, $\mathrm{T}$ cells, and mast cells and aggravating the inflammatory response [521,552]. The cytokine and chemokine receptor expression increases markedly in patients with critical disease compared to moderate disease, suggesting augmented recruitment of immune cells to inflammation sites [521]. Similarly, HIV-1 infection displays distinct cytokine profiles in the plasma, which increase in magnitude relative to increases in viral titers. Following the detection of HIV-1, there is typically a rapid and transient production of IL-15, CXCL10, and type-I IFNs as well as a rapid but sustained production of IL-18, TNF, IFN-gamma, and IL-22 [553]. IL-10 is also transiently produced following HIV-1 detection but is slightly delayed compared to the other cytokines [553]. Moreover, the early production of the chemokines CCL3 and CCL4 has been shown to exacerbate HIV-1 infection by recruiting target $\mathrm{CD}^{+} \mathrm{T}$ cells to the infection foci [554]. Progressive HIV-1 infection is typified by elevated production of the IL-6 cytokine as well as D-dimer, C-reactive protein, and CD14, which together are markers for increased risk of HIV-1associated mortality [555-562].

Nasopharyngeal SARS-CoV-2 viral load generally correlates with plasma levels of interferons and elevated cytokines. Moreover, viral load correlated significantly with IFN $\alpha$, IFN $\gamma$, and TRAIL levels. In patients who ultimately died of COVID-19, many chemokines responsible for monocyte and T cell recruitment and survival such as CCL1, CCL2, M-CSF, IL-2, Il-16, and CCL21 were elevated [69], suggesting pathological roles associated with host defense factors. 


\section{Interferon Response}

Pattern recognition followed by specific signal transduction events ultimately results in the production of interferons (IFNs), which are potent immune cytokines that upregulate IFN-stimulated genes (ISGs) and other cytokines that are essential for an effective antiviral response $[563,564]$. Among the IFNs, type I IFNs constitute the universal language, as they are produced by, and their receptors are found on all nucleated cells. However, responses are fine-tuned to perform a range of different activities dependent on the type I IFN subtype (message) and the responding cell type (receiver) [565]. As in many immune processes, both timing and magnitude of IFN responses are key to balance optimal antiviral efficiency and side effects of inflammation.

Coronaviruses and HIV, like many other viruses, have evolved antagonistic mechanisms to the host's antiviral response and both use different mechanisms to manipulate the IFN response: (1) avoidance, where the virus protects itself from recognition by PRRs; (2) suppression of IFN induction, where the virus inhibits the transcription of interferons [566]; and (3) suppression of IFN signaling, where viral proteins inhibit IFN alpha receptor (IFNAR) signaling [567].

In the airways, type I IFNs play important roles in protecting from the spread of respiratory viruses and are critical in initiating inflammatory responses. Although SARSCoV-2 is sensitive to IFN-I [537] and all IFN types can inhibit its replication in a dosedependent manner [568], recent studies have reported a delayed induction of the IFN-I response during SARS-CoV-2 infection [569,570], partly driven by SARS-CoV-2-promoted autophagy [571]. This delayed IFN induction is a prominent feature of COVID-19 and distinguishes SARS-CoV-2 infection from other viral infections such as SARS-CoV-1 and influenza A virus (IAV) [68,443]. Although the precise mechanisms used by SARS-CoV-2 to evade the innate immune response remain poorly understood, a number of SARS-CoV-2 proteins have been recently reported to antagonize the IFN response [572]. NSP6 binds TBK1 to suppress IRF3 phosphorylation, NSP13 binds and blocks TBK1 phosphorylation, and ORF6 binds KPNA2 to inhibit IRF3 nuclear translocation [573]. Other viral proteins antagonize IFN-I signaling by blocking STAT1/STAT2 phosphorylation or nuclear translocation $[68,439,572,573]$. Interestingly, IFN signaling during SARS-CoV-2 infection appears to be modulated not only by viral proteins but also by certain host factors. Inborn errors of TLR3- and IRF7-dependent type I IFN immunity were described in some patients with critical disease [574]. Furthermore, it was shown that some patients with life-threatening COVID-19 had neutralizing IgG auto-antibodies against IFN- $\omega$, IFN- $\alpha$, or both. These antibodies prevent the corresponding type I IFNs from blocking SARS-CoV-2 infection in vitro and were preferentially found in patients with severe COVID-19 [575-578]. Altogether, these data strongly support the notion that dysregulated type I IFN immunity underlies life-threatening COVID-19 pneumonia.

SARS-CoV-2 primarily targets airway epithelial cells, alveolar epithelial cells, vascular endothelial cells, and macrophages in the lung, all of which express ACE2, the predominant receptor for SARS-CoV-2 entry into host cells [33,579]. Both SARS-CoV-2 infection and subsequent release of inflammatory cytokines such as TNF $\alpha$ and IL- $\beta$ can enhance ACE2 shedding, which is attributable to the induced tissue damage [580]. Furthermore, ACE2 itself is an ISG, suggesting that SARS-CoV-2 may exploit IFN-driven ACE2 up-regulation to enhance infection [50]. Data showed that epithelial cells of the upper respiratory tract in patients with COVID-19 exhibit an average three-fold increase in ACE2 expression (mRNA) that correlates with IFN signals by immune cells. These include preferential expression of IFN- $\gamma$ by CTLs and of genes encoding its receptors (IFN- $\gamma$ R 1 and IFN- $\gamma$ R2) by secretory and ciliated cells, supporting the notion that ACE2 up-regulation is at least partially due to IFN$\gamma$ signaling by immune cells [521]. In addition, one of the central transcription factors of the IFN response, STAT1, was among the top predictors for ACE2 expression [521]. However, it was also observed that the benefit of IFN-induced ACE2 upregulation does not outweigh the IFN-induced antiviral activity to suppress viral replication once established [568], suggesting that the virus' ability to delay the IFN response early in infection is a crucial 
factor in disease progression. Interestingly, other factors such as tobacco smoke [581] and age [582] also regulate ACE2 mRNA levels and the IFN response. It was observed that older and/or smoking patients lacking IFN-I exhibit higher viral loads and require more aggressive medical intervention accompanied by a long time of stay in the intensive care unit [583]. Both enhanced ACE2 levels and reduced IFN-I production and ISG induction might be related to the higher susceptibility of the elderly population to COVID-19.

The type-I IFN response elicited during HIV-1 infection also requires a specific balance to control the viral titers and not cause detrimental inflammatory immunopathology [584]. HIV-1 is sensitive to type-I IFN, and consequently, the type-I IFN response offers control of HIV-1 titers early during infection [585-587]. However, misappropriated type-I IFN responses may lead to IFN-I desensitization, increased HIV-1 infection, and accelerated disease [588]. Indeed, comparative transcriptomics studies identified lower expression of ISGs in HIV-1-positive individuals who exhibited control of the infection and onset of disease compared to those in which disease progressed rapidly $[589,590]$. While type-I IFNs contribute to reducing HIV-1 viral load early in infection, the therapeutic use of type-I IFN has shown little to no benefits in HIV-1-infected patients with progressed infection and likely contributes to enhanced immunological disease [586,591,592]. In line with these findings, the therapeutic antagonism of type-I IFN receptor signaling during chronic HIV-1 infection has been demonstrated to control HIV-1 reservoirs, reverse inflammationassociated diseases, and rescue host anti-HIV-1 T cell immunity [593,594]. The advent of single genome amplification studies has highlighted the importance of robust initial control of HIV-1, as approximately $80 \%$ of HIV-1 infections were found to be established by a single founder virus [595-597]. In the instance of a misappropriated type-I IFN response, this single founder virus would likely represent an immune escape mutant, which likely contributes to subsequent IFN resistance in latent infection. In summary, it is apparent that the type-I IFN response is critical during initial SARS-CoV-2 and HIV-1 infections, but the timing, duration, and magnitude of the response must be regulated to appropriately prevent the progression of the infection and subsequent associated disease.

\section{SARS-CoV-2 and HIV-1 Co-Infection and Mutual Impact}

Data on the mutual impact of SARS-CoV-2 and HIV-1 co-infections are still unfolding. Early during the COVID-19 pandemic, mixed and partly contrasting results from clinical studies were reported, mainly based on differences in cohort composition, limited coinfection cases per study, and confounding factors, including differences in applied or absent ART [598-600]. While an immunocompromised status has been considered a general risk factor for COVID-19, it remained elusive whether the resulting decreased detrimental inflammatory response might even confer beneficial effects and mitigate clinical symptoms [601-605].

Most data showed that HIV-1-infected subjects receiving ART have a comparable risk of COVID-19 infection as healthy individuals, and HIV pre-exposure prophylaxis (PREP) users are not at risk of poorer COVID-19 disease outcomes than the general population when infected [606,607]. However, some studies showed an underrepresentation of severe COVID-19 cases among the HIV-1 patient population, implying that certain kinds of ART might lower the risk of severe COVID-19 outcomes [608]. Based on such findings and due to the similarities of potential HIV-1 and SARS-CoV-2 drug targets, especially the proteases, a repurposing of anti-HIV-1 drugs was initiated early in the pandemic. However, antiretroviral drugs exhibited only moderate effects against SARS-CoV-2 in vitro and had no efficacy in clinical trials [1,609-613].

Data on patients with uncontrolled HIV-1 infection, i.e., with detectable HIV-1 RNA and poor immunological status, are scarce but small studies indicated no pronounced impact of an ongoing HIV-1 infection on COVID-19 clinical outcome [614]. Although HIV-1 altered the response of $\mathrm{CD}^{+} \mathrm{T}, \mathrm{CD} 8^{+} \mathrm{T}$, and natural killer cell subsets, COVID-19 disease in people living with HIV (PWH) remained comparable to HIV-negative participants [615]. Of note, however, a study reported that, although PWH were not overrepresented among 
COVID-19 cases, these individuals had a higher rate of COVID-19-related complications, presumably due to a higher prevalence of underlying factors associated with more severe COVID-19 outcomes [616]. In contrast to some of the earlier studies, recent data showed that indeed there might be substantial morbidity and mortality from COVID-19 among PWH, even in the setting of HIV-1 suppression [617-619]. Factors associated with risk for severe COVID-19 in HIV-1-infected patients were low $\mathrm{CD}^{+} \mathrm{T}$ cell counts and discontinuation of ART. HIV-1-mediated CD4 ${ }^{+} \mathrm{T}$ cell depletion has been associated with impaired $\mathrm{T}$ cell and humoral immune responses to SARS-CoV-2 [620]. The only factor associated with mortality was a low CD4 ${ }^{+}$T cell set point, but not HIV-1 viral load or type of ART [604,621,622]. SARS-CoV-2-specific IgG concentrations and pseudovirus nAb titers, but not avidity, were lower among PWH compared with HIV-negative controls [623]. Moreover, black PWH had a substantially increased risk of severe disease, thus rendering African regions with a high prevalence of HIV-1 infection more vulnerable to COVID-19 and requiring closer surveillance [617]. The prolonged replication, enhanced evolutionary rates, and severe clinical relapse of SARS-CoV-2 in immunocompromised patients highlights the risk carried by individuals with a suppressed immune system, such as those with an active HIV-1 infection [293-296]. Of note, a vaccine efficacy study against the South African variant B.1.351 indicated that the Novavax vaccine is less effective in HIV-1-infected (49\% efficacy) compared to HIV-1-uninfected individuals (60\% efficacy) [624], corroborating an impact of HIV-1 infection on anti-SARS-CoV-2 immune responses and/or COVID-19 outcome.

While most studies have focused on the impact of HIV-1 infection on COVID-19, there are only limited data on the interference of COVID-19 on HIV-1. A modeling study estimated that the most significant risk of the COVID-19 pandemic on PWH comes from interrupted ART in resource-limited countries [625]. COVID-19 cases were reported where SARS-CoV-2 infection increased HIV-1 viral load and thus might foster HIV-1 viral rebound [626].

In summary, accumulating data suggest an underlying HIV-1 infection slightly increases the risk of severe COVID-19, particularly in patients that are sub-optimally treated and immunocompromised [627]. Studies with higher case numbers with full adjustment of confounders need to confirm these preliminary findings.

\section{Conclusions}

The raging AIDS and COVID-19 pandemics taught us important lessons on viral pathogenesis and made the causing agents HIV-1 and SARS-CoV-2 some of the world's best-studied viruses. Both viruses are of comparable structure with key components of enveloped viruses with positive-strand RNA genomes, but they differ profoundly in their basic functioning. SARS-CoV-2 is responsible for an acute, in most cases, self-limiting disease, which may exhibit respiratory symptoms at the initial stage with possible systemic dissemination if chronic disease stages are entered. Conversely, the integration of HIV-1 as a provirus into the host genome and its capacity to reside there for years underline the primary chronic nature of HIV-1 infection after a usually mild acute infection. The high error rate during reverse transcription makes HIV-1 a master of immune escape, with HIV-1 Ab immune evasion progressing rapidly and comprehensively in almost every patient. Furthermore, the massive glycan shield covering HIV-1 Env proteins and the depletion of critical immune cells during pathogenesis render HIV-1 a highly challenging virus to develop both curative approaches and vaccines against. In contrast, SARS-CoV-2's mutational activity is comparably silent, which facilitated the development of effective vaccines for emergency use in a record time of less than one year. Nevertheless, since the end of 2020, a series of mutant variants have increased in prevalence globally, presumably due to selective pressure by adaptive immunity. Continued monitoring efforts of circulating and emerging variants will be vital to optimizing current and developing new effective vaccine and treatment approaches against HIV-1 and SARS-CoV-2. Both viruses unite in having a broad array of cellular anomalies and a pronounced cytokine storm correlated with disease severity. HIV-1 and SARS-CoV-2 co-infection must be considered an additional 
risk since an underlying immunodeficiency impairs SARS-CoV-2 clearance, which in turn may accelerate clinical aggravation and facilitate enhanced and prolonged viral evolution, and subsequent SARS-CoV-2 immune or drug escape.

Author Contributions: R.D. performed analyses, generated the figures and tables, and conceptualized the study. R.D., K.M.C., A.M.V.-J. and M.D. wrote and edited the manuscript. All authors have read and agreed to the published version of the manuscript.

Funding: This work was supported by grants AI122953 (to R.D.) and R01AI143639 (to M.D.) from the National Institute of Allergy and Infectious Diseases (NIAID), by The G. Harold and Leila Y. Mathers Charitable Foundation (to M.D.) and by NYU Grossman School of Medicine Startup funds (to M.D.).

Data Availability Statement: Analyses were performed using publicly archived datasets as indicated. Protein structures were generated using pdb files downloaded from the RCSB Protein Data Bank (RCSB PDB; https:/ / www.rcsb.org/), the Electron Microscopy Data Bank (EMDB; https:/ /www. ebi.ac.uk/pdbe/emdb/), and the Zhang lab webpage on COVID-19 structure modeling (https: / / zhanglab.ccmb.med.umich.edu/COVID-19/). Viral sequences were downloaded from GISAID ( https: / / www.gisaid.org/) and the LANL HIV Databases (https:/ / www.hiv.lanl.gov/content/index).

Acknowledgments: The authors thank Flavia Camacho for administrative and technical support.

Conflicts of Interest: The authors declare no conflict of interest. The funders had no role in the design of the article, analyses, interpretation of data, writing of the manuscript, or the decision to publish the data.

\section{References}

1. WHO Solidarity Trial Consortium; Pan, H.; Peto, R.; Henao-Restrepo, A.M.; Preziosi, M.P.; Sathiyamoorthy, V.; Abdool Karim, Q.; Alejandria, M.M.; Hernandez Garcia, C.; Kieny, M.P.; et al. Repurposed Antiviral Drugs for Covid-19-Interim WHO Solidarity Trial Results. N. Engl. J. Med. 2020. [CrossRef]

2. Burton, D.R.; Walker, L.M. Rational Vaccine Design in the Time of COVID-19. Cell Host Microbe 2020, 27, 695-698. [CrossRef]

3. Hargreaves, J.; Davey, C.; Group for Lessons from Pandemic HIV Prevention for the COVID-19 Response. Three lessons for the COVID-19 response from pandemic HIV. Lancet HIV 2020, 7, e309-e311. [CrossRef]

4. Spach, D.H.; Budak, J.Z. HIV-2 Infection. Natl. HIV Curric. 2020. Available online: https://www.hiv.uw.edu/go/keypopulations/hiv-2/core-concept/all (accessed on 18 March 2021).

5. Sharp, P.M.; Hahn, B.H. Origins of HIV and the AIDS pandemic. Cold Spring Harb. Perspect. Med. 2011, 1, a006841. [CrossRef]

6. Zhu, N.; Zhang, D.; Wang, W.; Li, X.; Yang, B.; Song, J.; Zhao, X.; Huang, B.; Shi, W.; Lu, R.; et al. A Novel Coronavirus from Patients with Pneumonia in China, 2019. N. Engl. J. Med. 2020, 382, 727-733. [CrossRef]

7. Avert. ORIGIN OF HIV \& AIDS. Available online: https://www.avert.org/professionals/history-hiv-aids/origin\#footnote3_4i4 996m (accessed on 1 April 2021).

8. Zhu, T.; Korber, B.T.; Nahmias, A.J.; Hooper, E.; Sharp, P.M.; Ho, D.D. An African HIV-1 sequence from 1959 and implications for the origin of the epidemic. Nature 1998, 391, 594-597. [CrossRef]

9. Bryner, J. 1st known case of coronavirus traced back to November in China. Available online: https://www.livescience.com/ first-case-coronavirus-found.html (accessed on 25 March 2021).

10. World Health Organization (WHO). Listings of WHO's response to COVID-19. Available online: https://www.who.int/news / item/29-06-2020-covid timeline (accessed on 5 June 2021).

11. Faria, N.R.; Rambaut, A.; Suchard, M.A.; Baele, G.; Bedford, T.; Ward, M.J.; Tatem, A.J.; Sousa, J.D.; Arinaminpathy, N.; Pepin, J.; et al. HIV epidemiology. The early spread and epidemic ignition of HIV-1 in human populations. Science 2014, 346, 56-61. [CrossRef]

12. Duchene, S.; Featherstone, L.; Haritopoulou-Sinanidou, M.; Rambaut, A.; Lemey, P.; Baele, G. Temporal signal and the phylodynamic threshold of SARS-CoV-2. Virus Evol. 2020, 6. [CrossRef]

13. Pekar, J.; Worobey, M.; Moshiri, N.; Scheffler, K.; Wertheim, J.O. Timing the SARS-CoV-2 index case in Hubei province. Science 2021. [CrossRef]

14. Andersen, K.G.; Rambaut, A.; Lipkin, W.I.; Holmes, E.C.; Garry, R.F. The proximal origin of SARS-CoV-2. Nat. Med. 2020, 26, 450-452. [CrossRef]

15. Boni, M.F.; Lemey, P.; Jiang, X.; Lam, T.T.; Perry, B.W.; Castoe, T.A.; Rambaut, A.; Robertson, D.L. Evolutionary origins of the SARS-CoV-2 sarbecovirus lineage responsible for the COVID-19 pandemic. Nat. Microbiol. 2020, 5, 1408-1417. [CrossRef]

16. Mallapaty, S. Animal source of the coronavirus continues to elude scientists. Nature 2020. [CrossRef]

17. UNAIDS. UNAIDS Data 2020. Available online: https://www.unaids.org/en/resources/documents/2020/unaids-data (accessed on 5 March 2021).

18. Worldometer. COVID-19 Coronavirus Pandemic. Available online: https://www.worldometers.info/coronavirus / (accessed on 15 June 2021). 
19. Islam, N.; Shkolnikov, V.M.; Acosta, R.J.; Klimkin, I.; Kawachi, I.; Irizarry, R.A.; Alicandro, G.; Khunti, K.; Yates, T.; Jdanov, D.A.; et al. Excess deaths associated with covid-19 pandemic in 2020: Age and sex disaggregated time series analysis in 29 high income countries. BMJ 2021, 373, n1137. [CrossRef]

20. Baltimore, D. Expression of animal virus genomes. Bacteriol. Rev. 1971, 35, 235-241. [CrossRef]

21. Mahmoudabadi, G.; Phillips, R. A comprehensive and quantitative exploration of thousands of viral genomes. eLife 2018, 7, e31955. [CrossRef]

22. Liu, J.; Wright, E.R.; Winkler, H. 3D visualization of HIV virions by cryoelectron tomography. Methods Enzym. 2010, 483, 267-290. [CrossRef]

23. Laue, M.; Kauter, A.; Hoffmann, T.; Moller, L.; Michel, J.; Nitsche, A. Morphometry of SARS-CoV and SARS-CoV-2 particles in ultrathin plastic sections of infected Vero cell cultures. Sci. Rep. 2021, 11, 3515. [CrossRef]

24. Zhu, P.; Chertova, E.; Bess, J., Jr.; Lifson, J.D.; Arthur, L.O.; Liu, J.; Taylor, K.A.; Roux, K.H. Electron tomography analysis of envelope glycoprotein trimers on HIV and simian immunodeficiency virus virions. Proc. Natl. Acad. Sci. USA 2003, 100, 15812-15817. [CrossRef] [PubMed]

25. Ke, Z.; Oton, J.; Qu, K.; Cortese, M.; Zila, V.; McKeane, L.; Nakane, T.; Zivanov, J.; Neufeldt, C.J.; Cerikan, B.; et al. Structures and distributions of SARS-CoV-2 spike proteins on intact virions. Nature 2020, 588, 498-502. [CrossRef] [PubMed]

26. Liu, J.; Bartesaghi, A.; Borgnia, M.J.; Sapiro, G.; Subramaniam, S. Molecular architecture of native HIV-1 gp120 trimers. Nature 2008, 455, 109-113. [CrossRef] [PubMed]

27. Klein, S.; Cortese, M.; Winter, S.L.; Wachsmuth-Melm, M.; Neufeldt, C.J.; Cerikan, B.; Stanifer, M.L.; Boulant, S.; Bartenschlager, R.; Chlanda, P. SARS-CoV-2 structure and replication characterized by in situ cryo-electron tomography. Nat. Commun. 2020, 11, 5885. [CrossRef]

28. Turonova, B.; Sikora, M.; Schurmann, C.; Hagen, W.J.H.; Welsch, S.; Blanc, F.E.C.; von Bulow, S.; Gecht, M.; Bagola, K.; Horner, C.; et al. In situ structural analysis of SARS-CoV-2 spike reveals flexibility mediated by three hinges. Science 2020, 370, 203-208. [CrossRef]

29. Wrapp, D.; Wang, N.; Corbett, K.S.; Goldsmith, J.A.; Hsieh, C.L.; Abiona, O.; Graham, B.S.; McLellan, J.S. Cryo-EM structure of the 2019-nCoV spike in the prefusion conformation. Science 2020, 367, 1260-1263. [CrossRef]

30. Los Alamos National Laboratory. Los Alamos National Laboratory HIV Databases. Available online: https://www.hiv.lanl.gov/ content/index (accessed on 15 March 2021).

31. GISAID. GISAID Database. Available online: https:/ / www.gisaid.org/ (accessed on 15 March 2021).

32. Decroly, E.; Vandenbranden, M.; Ruysschaert, J.M.; Cogniaux, J.; Jacob, G.S.; Howard, S.C.; Marshall, G.; Kompelli, A.; Basak, A.; Jean, F.; et al. The convertases furin and PC1 can both cleave the human immunodeficiency virus (HIV)-1 envelope glycoprotein gp160 into gp120 (HIV-1 SU) and gp41 (HIV-I TM). J. Biol. Chem. 1994, 269, 12240-12247. [CrossRef]

33. Hoffmann, M.; Kleine-Weber, H.; Schroeder, S.; Kruger, N.; Herrler, T.; Erichsen, S.; Schiergens, T.S.; Herrler, G.; Wu, N.H.; Nitsche, A.; et al. SARS-CoV-2 Cell Entry Depends on ACE2 and TMPRSS2 and Is Blocked by a Clinically Proven Protease Inhibitor. Cell 2020, 181, 271-280.e8. [CrossRef]

34. Savastano, A.; Ibáñez de Opakua, A.; Rankovic, M.; Zweckstetter, M. Nucleocapsid protein of SARS-CoV-2 phase separates into RNA-rich polymerase-containing condensates. Nat. Commun. 2020, 11, 6041. [CrossRef]

35. Campbell, E.M.; Hope, T.J. HIV-1 capsid: The multifaceted key player in HIV-1 infection. Nat. Rev. Microbiol. 2015, 13, 471-483. [CrossRef] [PubMed]

36. Mattei, S.; Glass, B.; Hagen, W.J.H.; Kräusslich, H.-G.; Briggs, J.A.G. The structure and flexibility of conical HIV-1 capsids determined within intact virions. Science 2016, 354, 1434-1437. [CrossRef]

37. Changchang, C.; Zhaokui, C.; Xia, X.; Jian, R.; Naijing, H.; Minnan, Y.; Xiaorui, X.; Bing, Z.; Xiangxi, W.; Jianwei, W.; et al. The architecture of the SARS-CoV-2 RNA genome. Res. Sq. 2021. [CrossRef]

38. Watts, J.M.; Dang, K.K.; Gorelick, R.J.; Leonard, C.W.; Bess, J.W., Jr.; Swanstrom, R.; Burch, C.L.; Weeks, K.M. Architecture and secondary structure of an entire HIV-1 RNA genome. Nature 2009, 460, 711-716. [CrossRef]

39. Cuevas, J.M.; Geller, R.; Garijo, R.; Lopez-Aldeguer, J.; Sanjuan, R. Extremely High Mutation Rate of HIV-1 In Vivo. PLoS Biol. 2015, 13, e1002251. [CrossRef]

40. Maljkovic Berry, I.; Ribeiro, R.; Kothari, M.; Athreya, G.; Daniels, M.; Lee, H.Y.; Bruno, W.; Leitner, T. Unequal evolutionary rates in the human immunodeficiency virus type 1 (HIV-1) pandemic: The evolutionary rate of HIV-1 slows down when the epidemic rate increases. J. Virol. 2007, 81, 10625-10635. [CrossRef]

41. De Azevedo, S.S.D.; Caetano, D.G.; Cortes, F.H.; Teixeira, S.L.M.; Dos Santos Silva, K.; Hoagland, B.; Grinsztejn, B.; Veloso, V.G.; Morgado, M.G.; Bello, G. Highly divergent patterns of genetic diversity and evolution in proviral quasispecies from HIV controllers. Retrovirology 2017, 14, 29. [CrossRef] [PubMed]

42. Kosakovsky Pond, S.L.; Weaver, S.; Leigh Brown, A.J.; Wertheim, J.O. HIV-TRACE (TRAnsmission Cluster Engine): A Tool for Large Scale Molecular Epidemiology of HIV-1 and Other Rapidly Evolving Pathogens. Mol. Biol. Evol. 2018, 35, 1812-1819. [CrossRef] [PubMed]

43. Al Khatib, H.A.; Benslimane, F.M.; Elbashir, I.E.; Coyle, P.V.; Al Maslamani, M.A.; Al-Khal, A.; Al Thani, A.A.; Yassine, H.M. Within-Host Diversity of SARS-CoV-2 in COVID-19 Patients With Variable Disease Severities. Front. Cell Infect. Microbiol. 2020, 10, 575613. [CrossRef] [PubMed] 
44. Mohammadi, P.; Desfarges, S.; Bartha, I.; Joos, B.; Zangger, N.; Munoz, M.; Gunthard, H.F.; Beerenwinkel, N.; Telenti, A.; Ciuffi, A. 24 hours in the life of HIV-1 in a T cell line. PLoS Pathog. 2013, 9, e1003161. [CrossRef]

45. Murray, J.M.; Kelleher, A.D.; Cooper, D.A. Timing of the components of the HIV life cycle in productively infected CD4+ T cells in a population of HIV-infected individuals. J. Virol. 2011, 85, 10798-10805. [CrossRef]

46. Bar-On, Y.M.; Flamholz, A.; Phillips, R.; Milo, R. SARS-CoV-2 (COVID-19) by the numbers. eLife 2020, 9. [CrossRef]

47. V'kovski, P.; Kratzel, A.; Steiner, S.; Stalder, H.; Thiel, V. Coronavirus biology and replication: Implications for SARS-CoV-2. Nat. Res. 2020. [CrossRef]

48. De Vries, M.; Mohamed, A.S.; Prescott, R.A.; Valero-Jimenez, A.M.; Desvignes, L.; O'Connor, R.; Steppan, C.; Anderson, A.S.; Binder, J.; Dittmann, M. Comparative study of a 3CLpro inhibitor and remdesivir against both major SARS-CoV-2 clades in human airway models. J. Virol. 2020. [CrossRef]

49. Moir, S.; Chun, T.W.; Fauci, A.S. Pathogenic mechanisms of HIV disease. Annu Rev. Pathol. 2011, 6, 223-248. [CrossRef]

50. Ziegler, C.G.K.; Allon, S.J.; Nyquist, S.K.; Mbano, I.M.; Miao, V.N.; Tzouanas, C.N.; Cao, Y.; Yousif, A.S.; Bals, J.; Hauser, B.M.; et al. SARS-CoV-2 Receptor ACE2 Is an Interferon-Stimulated Gene in Human Airway Epithelial Cells and Is Detected in Specific Cell Subsets across Tissues. Cell 2020, 181, 1016-1035.e19. [CrossRef] [PubMed]

51. Blumenthal, R.; Durell, S.; Viard, M. HIV entry and envelope glycoprotein-mediated fusion. J. Biol. Chem. 2012, 287, 40841-40849. [CrossRef]

52. Wilen, C.B.; Tilton, J.C.; Doms, R.W. HIV: Cell binding and entry. Cold Spring Harb. Perspect. Med. 2012, 2. [CrossRef] [PubMed]

53. Benton, D.J.; Wrobel, A.G.; Xu, P.; Roustan, C.; Martin, S.R.; Rosenthal, P.B.; Skehel, J.J.; Gamblin, S.J. Receptor binding and priming of the spike protein of SARS-CoV-2 for membrane fusion. Nature 2020, 588, 327-330. [CrossRef] [PubMed]

54. Landais, E.; Huang, X.; Havenar-Daughton, C.; Murrell, B.; Price, M.A.; Wickramasinghe, L.; Ramos, A.; Bian, C.B.; Simek, M.; Allen, S.; et al. Broadly Neutralizing Antibody Responses in a Large Longitudinal Sub-Saharan HIV Primary Infection Cohort. PLoS Pathog. 2016, 12, e1005369. [CrossRef] [PubMed]

55. Prevost, J.; Gasser, R.; Beaudoin-Bussieres, G.; Richard, J.; Duerr, R.; Laumaea, A.; Anand, S.P.; Goyette, G.; Benlarbi, M.; Ding, S.; et al. Cross-sectional evaluation of humoral responses against SARS-CoV-2 Spike. Cell Rep. Med. 2020. [CrossRef]

56. Seow, J.; Graham, C.; Merrick, B.; Acors, S.; Pickering, S.; Steel, K.J.A.; Hemmings, O.; O’Byrne, A.; Kouphou, N.; Galao, R.P.; et al. Longitudinal observation and decline of neutralizing antibody responses in the three months following SARS-CoV-2 infection in humans. Nat. Microbiol. 2020, 5, 1598-1607. [CrossRef]

57. Muecksch, F.; Weisblum, Y.; Barnes, C.O.; Schmidt, F.; Schaefer-Babajew, D.; Lorenzi, J.C.C.; Flyak, A.I.; DeLaitsch, A.T.; HueyTubman, K.E.; Hou, S.; et al. Development of potency, breadth and resilience to viral escape mutations in SARS-CoV-2 neutralizing antibodies. bioRxiv 2021. [CrossRef]

58. McMichael, A.J.; Rowland-Jones, S.L. Cellular immune responses to HIV. Nature 2001, 410, 980-987. [CrossRef] [PubMed]

59. Chen, Z.; John Wherry, E. T cell responses in patients with COVID-19. Nat. Rev. Immunol. 2020, 20, 529-536. [CrossRef]

60. Files, J.K.; Boppana, S.; Perez, M.D.; Sarkar, S.; Lowman, K.E.; Qin, K.; Sterrett, S.; Carlin, E.; Bansal, A.; Sabbaj, S.; et al. Sustained cellular immune dysregulation in individuals recovering from SARS-CoV-2 infection. J. Clin. Invest. 2020. [CrossRef]

61. Rodda, L.B.; Netland, J.; Shehata, L.; Pruner, K.B.; Morawski, P.A.; Thouvenel, C.D.; Takehara, K.K.; Eggenberger, J.; Hemann, E.A.; Waterman, H.R.; et al. Functional SARS-CoV-2-Specific Immune Memory Persists after Mild COVID-19. Cell 2020. [CrossRef]

62. Schulte-Schrepping, J.; Reusch, N.; Paclik, D.; Bassler, K.; Schlickeiser, S.; Zhang, B.; Kramer, B.; Krammer, T.; Brumhard, S.; Bonaguro, L.; et al. Severe COVID-19 Is Marked by a Dysregulated Myeloid Cell Compartment. Cell 2020, 182, 1419-1440.e23. [CrossRef]

63. Yao, C.; Bora, S.A.; Parimon, T.; Zaman, T.; Friedman, O.A.; Palatinus, J.A.; Surapaneni, N.S.; Matusov, Y.P.; Cerro Chiang, G.; Kassar, A.G.; et al. Cell-Type-Specific Immune Dysregulation in Severely Ill COVID-19 Patients. Cell Rep. 2020. [CrossRef]

64. McMichael, A.J.; Borrow, P.; Tomaras, G.D.; Goonetilleke, N.; Haynes, B.F. The immune response during acute HIV-1 infection: Clues for vaccine development. Nat. Rev. Immunol. 2010, 10, 11-23. [CrossRef] [PubMed]

65. Yin, X.; Langer, S.; Zhang, Z.; Herbert, K.M.; Yoh, S.; Konig, R.; Chanda, S.K. Sensor Sensibility-HIV-1 and the Innate Immune Response. Cells 2020, 9, 254. [CrossRef] [PubMed]

66. Arunachalam, P.S.; Wimmers, F.; Mok, C.K.P.; Perera, R.; Scott, M.; Hagan, T.; Sigal, N.; Feng, Y.; Bristow, L.; Tak-Yin Tsang, O.; et al. Systems biological assessment of immunity to mild versus severe COVID-19 infection in humans. Science 2020, 369, 1210-1220. [CrossRef] [PubMed]

67. Galani, I.E.; Rovina, N.; Lampropoulou, V.; Triantafyllia, V.; Manioudaki, M.; Pavlos, E.; Koukaki, E.; Fragkou, P.C.; Panou, V.; Rapti, V.; et al. Untuned antiviral immunity in COVID-19 revealed by temporal type I/III interferon patterns and flu comparison. Nat. Immunol. 2021, 22, 32-40. [CrossRef]

68. Hadjadj, J.; Yatim, N.; Barnabei, L.; Corneau, A.; Boussier, J.; Smith, N.; Pere, H.; Charbit, B.; Bondet, V.; Chenevier-Gobeaux, C.; et al. Impaired type I interferon activity and inflammatory responses in severe COVID-19 patients. Science 2020, 369, 718-724. [CrossRef]

69. Lucas, C.; Wong, P.; Klein, J.; Castro, T.B.R.; Silva, J.; Sundaram, M.; Ellingson, M.K.; Mao, T.; Oh, J.E.; Israelow, B.; et al. Longitudinal analyses reveal immunological misfiring in severe COVID-19. Nature 2020, 584, 463-469. [CrossRef] [PubMed]

70. Tay, M.Z.; Poh, C.M.; Renia, L.; MacAry, P.A.; Ng, L.F.P. The trinity of COVID-19: Immunity, inflammation and intervention. Nat. Rev. Immunol. 2020. [CrossRef] [PubMed]

71. Moylett, E.H.; Shearer, W.T. HIV: Clinical manifestations. J. Allergy Clin. Immunol. 2002, 110, 3-16. [CrossRef] 
72. Simon, V.; Ho, D.D.; Abdool Karim, Q. HIV/AIDS epidemiology, pathogenesis, prevention, and treatment. Lancet 2006, 368, 489-504. [CrossRef]

73. Huang, C.; Wang, Y.; Li, X.; Ren, L.; Zhao, J.; Hu, Y.; Zhang, L.; Fan, G.; Xu, J.; Gu, X.; et al. Clinical features of patients infected with 2019 novel coronavirus in Wuhan, China. Lancet 2020, 395, 497-506. [CrossRef]

74. Tang, D.; Comish, P.; Kang, R. The hallmarks of COVID-19 disease. PLoS Pathog. 2020, 16, e1008536. [CrossRef] [PubMed]

75. Wadman, M.; Couzin-Frankel, J.; Kaiser, J.; Matacic, C. A rampage through the body. Science 2020, 368, 356-360. [CrossRef]

76. Nalbandian, A.; Sehgal, K.; Gupta, A.; Madhavan, M.V.; McGroder, C.; Stevens, J.S.; Cook, J.R.; Nordvig, A.S.; Shalev, D.; Sehrawat, T.S.; et al. Post-acute COVID-19 syndrome. Nat. Med. 2021. [CrossRef] [PubMed]

77. Al-Aly, Z.; Xie, Y.; Bowe, B. High-dimensional characterization of post-acute sequelae of COVID-19. Nature 2021. [CrossRef]

78. HIVinfo. FDA-Approved HIV Medicines. Available online: https://hivinfo.nih.gov/understanding-hiv/fact-sheets/fdaapproved-hiv-medicines (accessed on 15 March 2021).

79. Saag, M.S. HIV Infection-Screening, Diagnosis, and Treatment. N. Engl. J. Med. 2021, 384, 2131-2143. [CrossRef] [PubMed]

80. Valle, C.; Martin, B.; Touret, F.; Shannon, A.; Canard, B.; Guillemot, J.C.; Coutard, B.; Decroly, E. Drugs against SARS-CoV-2: What do we know about their mode of action? Rev. Med. Virol. 2020, 30, 1-10. [CrossRef] [PubMed]

81. Duerr, R.; Gorny, M.K. V2-Specific Antibodies in HIV-1 Vaccine Research and Natural Infection: Controllers or Surrogate Markers. Vaccines 2019, 7, 82. [CrossRef] [PubMed]

82. UNAIDS. HVTN 702 Clinical Trial of an HIV Vaccine Stopped. Available online: https://www.unaids.org/en/resources/ presscentre/pressreleaseandstatementarchive/2020/february/20200204_vaccine (accessed on 10 March 2021).

83. Krammer, F. SARS-CoV-2 vaccines in development. Nature 2020, 586, 516-527. [CrossRef] [PubMed]

84. Creech, C.B.; Walker, S.C.; Samuels, R.J. SARS-CoV-2 Vaccines. JAMA 2021. [CrossRef] [PubMed]

85. Kyriakidis, N.C.; Lopez-Cortes, A.; Gonzalez, E.V.; Grimaldos, A.B.; Prado, E.O. SARS-CoV-2 vaccines strategies: A comprehensive review of phase 3 candidates. NPJ Vaccines 2021, 6, 28. [CrossRef] [PubMed]

86. Rerks-Ngarm, S.; Pitisuttithum, P.; Nitayaphan, S.; Kaewkungwal, J.; Chiu, J.; Paris, R.; Premsri, N.; Namwat, C.; de Souza, M.; Adams, E.; et al. Vaccination with ALVAC and AIDSVAX to prevent HIV-1 infection in Thailand. N. Engl. J. Med. 2009, 361, 2209-2220. [CrossRef]

87. McMahan, K.; Yu, J.; Mercado, N.B.; Loos, C.; Tostanoski, L.H.; Chandrashekar, A.; Liu, J.; Peter, L.; Atyeo, C.; Zhu, A.; et al. Correlates of protection against SARS-CoV-2 in rhesus macaques. Nature 2020. [CrossRef]

88. Pettersen, E.F.; Goddard, T.D.; Huang, C.C.; Couch, G.S.; Greenblatt, D.M.; Meng, E.C.; Ferrin, T.E. UCSF Chimera-A visualization system for exploratory research and analysis. J. Comput Chem. 2004, 25, 1605-1612. [CrossRef]

89. Zhang Lab. I-TASSER-Genome-Wide Structure and Function Modeling of SARS-CoV-2. Available online: https: / / zhanglab.ccmb. med.umich.edu/COVID-19/ (accessed on 7 March 2021).

90. Glycosciences de GlyProt. In Silico Glycosylation of Proteins. Available online: http://www.glycosciences.de/modeling/ glyprot/php/main.php (accessed on 5 March 2021).

91. Cao, L.; Diedrich, J.K.; Kulp, D.W.; Pauthner, M.; He, L.; Park, S.R.; Sok, D.; Su, C.Y.; Delahunty, C.M.; Menis, S.; et al. Global site-specific N-glycosylation analysis of HIV envelope glycoprotein. Nat. Commun. 2017, 8, 14954. [CrossRef]

92. Watanabe, Y.; Allen, J.D.; Wrapp, D.; McLellan, J.S.; Crispin, M. Site-specific glycan analysis of the SARS-CoV-2 spike. Science 2020. [CrossRef]

93. Elbe, S.; Buckland-Merrett, G. Data, disease and diplomacy: GISAID's innovative contribution to global health. Glob. Chall. 2017, 1, 33-46. [CrossRef]

94. Miller, M.A.; Pfeiffer, W.; Schwartz, T. Creating the CIPRES Science Gateway for Inference of Large Phylogenetic Trees. In Proceedings of the Gateway Computing Environments Workshop, New Orleans, LA, USA, 14 November 2010; pp. 1-8.

95. Rambaut, A. FigTree, 1.4; Andrew Rambaut: Edinburgh, UK, 2012.

96. RStudio. RStudio Team: A Bundle of RStudio's Popular Professional Software for Statistical Data Analysis, Package Management, and Sharing Data Products; RStudio, Inc.: Boston, MA, USA, 2015.

97. R_Core_Team. R: A Language and Environment for Statistical Computing; R Foundation for Statistical Computing: Vienna, Austria, 2014; Available online: http:/ / www.R-project.org/ (accessed on 11 March 2021).

98. WHO. Zoonoses. Available online: https://www.who.int/news-room/fact-sheets/detail/zoonoses (accessed on 3 June 2021).

99. Sagnelli, C.; Uberti-Foppa, C.; Bagaglio, S.; Cella, E.; Scolamacchia, V.; Hasson, H.; Salpietro, S.; Messina, E.; Morsica, G.; Angeletti, S.; et al. Molecular epidemiology of HIV-1 infection in immigrant population in northern Italy. Epidemiol. Infect. 2020, 148, e19. [CrossRef]

100. Gao, F.; Yue, L.; White, A.T.; Pappas, P.G.; Barchue, J.; Hanson, A.P.; Greene, B.M.; Sharp, P.M.; Shaw, G.M.; Hahn, B.H. Human infection by genetically diverse SIVSM-related HIV-2 in west Africa. Nature 1992, 358, 495-499. [CrossRef] [PubMed]

101. Sharp, P.M.; Hahn, B.H. The evolution of HIV-1 and the origin of AIDS. Philos Trans. R Soc. Lond B Biol. Sci. 2010, 365, $2487-2494$. [CrossRef] [PubMed]

102. Ayouba, A.; Souquieres, S.; Njinku, B.; Martin, P.M.; Muller-Trutwin, M.C.; Roques, P.; Barre-Sinoussi, F.; Mauclere, P.; Simon, F.; Nerrienet, E. HIV-1 group N among HIV-1-seropositive individuals in Cameroon. AIDS 2000, 14, 2623-2625. [CrossRef]

103. D'Arc, M.; Ayouba, A.; Esteban, A.; Learn, G.H.; Boue, V.; Liegeois, F.; Etienne, L.; Tagg, N.; Leendertz, F.H.; Boesch, C.; et al. Origin of the HIV-1 group O epidemic in western lowland gorillas. Proc. Natl. Acad Sci. USA 2015, 112, E1343-E1352. [CrossRef] [PubMed] 
104. Gurtler, L.G.; Hauser, P.H.; Eberle, J.; von Brunn, A.; Knapp, S.; Zekeng, L.; Tsague, J.M.; Kaptue, L. A new subtype of human immunodeficiency virus type 1 (MVP-5180) from Cameroon. J. Virol. 1994, 68, 1581-1585. [CrossRef] [PubMed]

105. Simon, F.; Mauclere, P.; Roques, P.; Loussert-Ajaka, I.; Muller-Trutwin, M.C.; Saragosti, S.; Georges-Courbot, M.C.; Barre-Sinoussi, F.; Brun-Vezinet, F. Identification of a new human immunodeficiency virus type 1 distinct from group M and group O. Nat. Med. 1998, 4, 1032-1037. [CrossRef]

106. Van Heuverswyn, F.; Li, Y.; Neel, C.; Bailes, E.; Keele, B.F.; Liu, W.; Loul, S.; Butel, C.; Liegeois, F.; Bienvenue, Y.; et al. Human immunodeficiency viruses: SIV infection in wild gorillas. Nature 2006, 444, 164. [CrossRef]

107. LANL. HIV Sequence Database; Los Alamos National Laboratory: Los Alamos, NM, USA, 2021.

108. Peeters, M.; Courgnaud, V.; Abela, B.; Auzel, P.; Pourrut, X.; Bibollet-Ruche, F.; Loul, S.; Liegeois, F.; Butel, C.; Koulagna, D.; et al. Risk to human health from a plethora of simian immunodeficiency viruses in primate bushmeat. Emerg. Infect. Dis. 2002, 8, 451-457. [CrossRef]

109. Ye, Z.-W.; Yuan, S.; Yuen, K.-S.; Fung, S.-Y.; Chan, C.-P.; Jin, D.-Y. Zoonotic origins of human coronaviruses. Int. J. Biol. Sci. 2020, 16, 1686-1697. [CrossRef]

110. Latinne, A.; Hu, B.; Olival, K.J.; Zhu, G.; Zhang, L.; Li, H.; Chmura, A.A.; Field, H.E.; Zambrana-Torrelio, C.; Epstein, J.H.; et al. Origin and cross-species transmission of bat coronaviruses in China. Nat. Commun. 2020, 11, 4235. [CrossRef] [PubMed]

111. Ghai, R.; Carpenter, A.; Liew, A.; Martin, K.; Herring, M.; Gerber, S.; Hall, A.; Sleeman, J.; VonDobschuetz, S.; Behravesh, C.B. Animal Reservoirs and Hosts for Emerging Alphacoronaviruses and Betacoronaviruses. Emerg. Infect. Dis. J. 2021, $27,1015$. [CrossRef] [PubMed]

112. Mahdy, M.A.A.; Younis, W.; Ewaida, Z. An Overview of SARS-CoV-2 and Animal Infection. Front. Vet. Sci. 2020, 7. [CrossRef]

113. Van Dorp, L.; Acman, M.; Richard, D.; Shaw, L.P.; Ford, C.E.; Ormond, L.; Owen, C.J.; Pang, J.; Tan, C.C.S.; Boshier, F.A.T.; et al. Emergence of genomic diversity and recurrent mutations in SARS-CoV-2. Infect. Genet. Evol. 2020, 83, 104351. [CrossRef]

114. Zhou, P.; Yang, X.L.; Wang, X.G.; Hu, B.; Zhang, L.; Zhang, W.; Si, H.R.; Zhu, Y.; Li, B.; Huang, C.L.; et al. A pneumonia outbreak associated with a new coronavirus of probable bat origin. Nature 2020, 579, 270-273. [CrossRef]

115. Zhang, Y.-Z.; Holmes, E.C. A Genomic Perspective on the Origin and Emergence of SARS-CoV-2. Cell 2020, $181,223-227$. [CrossRef]

116. Wrobel, A.G.; Benton, D.J.; Xu, P.; Roustan, C.; Martin, S.R.; Rosenthal, P.B.; Skehel, J.J.; Gamblin, S.J. SARS-CoV-2 and bat RaTG13 spike glycoprotein structures inform on virus evolution and furin-cleavage effects. Nat. Struct. Mol. Biol. 2020, $27,763-767$. [CrossRef] [PubMed]

117. Xiao, K.; Zhai, J.; Feng, Y.; Zhou, N.; Zhang, X.; Zou, J.-J.; Li, N.; Guo, Y.; Li, X.; Shen, X.; et al. Isolation of SARS-CoV-2-related coronavirus from Malayan pangolins. Nature 2020, 583, 286-289. [CrossRef]

118. Makarenkov, V.; Mazoure, B.; Rabusseau, G.; Legendre, P. Horizontal gene transfer and recombination analysis of SARS-CoV-2 genes helps discover its close relatives and shed light on its origin. BMC Ecol. Evol. 2021, 21, 5. [CrossRef]

119. Johnson, B.A.; Xie, X.; Bailey, A.L.; Kalveram, B.; Lokugamage, K.G.; Muruato, A.; Zou, J.; Zhang, X.; Juelich, T.; Smith, J.K.; et al. Loss of furin cleavage site attenuates SARS-CoV-2 pathogenesis. Nature 2021. [CrossRef]

120. Tang, X.; Wu, C.; Li, X.; Song, Y.; Yao, X.; Wu, X.; Duan, Y.; Zhang, H.; Wang, Y.; Qian, Z.; et al. On the origin and continuing evolution of SARS-CoV-2. Natl. Sci. Rev. 2020. [CrossRef]

121. Wacharapluesadee, S.; Tan, C.W.; Maneeorn, P.; Duengkae, P.; Zhu, F.; Joyjinda, Y.; Kaewpom, T.; Chia, W.N.; Ampoot, W.; Lim, B.L.; et al. Evidence for SARS-CoV-2 related coronaviruses circulating in bats and pangolins in Southeast Asia. Nat. Commun. 2021, 12, 972. [CrossRef]

122. Coronaviridae Study Group of the International Committee on Taxonomy of V. The species Severe acute respiratory syndromerelated coronavirus: Classifying 2019-nCoV and naming it SARS-CoV-2. Nat. Microbiol. 2020, 5, 536-544. [CrossRef] [PubMed]

123. German Advisory Committee Blood, SAOPTBB. Human Immunodeficiency Virus (HIV). Transfus. Med. Hemother. 2016, 43, 203-222. [CrossRef] [PubMed]

124. Klein, J.S.; Bjorkman, P.J. Few and Far Between: How HIV May Be Evading Antibody Avidity. PLoS Pathog. 2010, 6, e1000908. [CrossRef] [PubMed]

125. McCormick, K.D.; Jacobs, J.L.; Mellors, J.W. The emerging plasticity of SARS-CoV-2. Science 2021, 371, 1306-1308. [CrossRef]

126. Rambaut, A.; Posada, D.; Crandall, K.A.; Holmes, E.C. The causes and consequences of HIV evolution. Nat. Rev. Genet. 2004, 5, 52-61. [CrossRef]

127. Dürr, R.; Keppler, O.; Christ, F.; Crespan, E.; Garbelli, A.; Maga, G.; Dietrich, U. Targeting Cellular Cofactors in HIV Therapy. In Therapy of Viral Infections; Diederich, W.E., Steuber, H., Eds.; Springer: Berlin/Heidelberg, Germany, 2015; pp. 183-222. [CrossRef]

128. Gordon, D.E.; Jang, G.M.; Bouhaddou, M.; Xu, J.; Obernier, K.; White, K.M.; O’Meara, M.J.; Rezelj, V.V.; Guo, J.Z.; Swaney, D.L.; et al. A SARS-CoV-2 protein interaction map reveals targets for drug repurposing. Nature 2020, 583, 459-468. [CrossRef]

129. Kim, D.; Lee, J.Y.; Yang, J.S.; Kim, J.W.; Kim, V.N.; Chang, H. The Architecture of SARS-CoV-2 Transcriptome. Cell 2020, 181, 914-921.e10. [CrossRef] [PubMed]

130. Berndsen, Z.T.; Chakraborty, S.; Wang, X.; Cottrell, C.A.; Torres, J.L.; Diedrich, J.K.; Lopez, C.A.; Yates, J.R., 3rd; van Gils, M.J.; Paulson, J.C.; et al. Visualization of the HIV-1 Env glycan shield across scales. Proc. Natl. Acad. Sci. USA 2020, 117, 28014-28025. [CrossRef] [PubMed]

131. Cai, Y.; Zhang, J.; Xiao, T.; Peng, H.; Sterling, S.M.; Walsh, R.M., Jr.; Rawson, S.; Rits-Volloch, S.; Chen, B. Distinct conformational states of SARS-CoV-2 spike protein. Science 2020, 369, 1586-1592. [CrossRef] [PubMed] 
132. Tran, E.E.H.; Borgnia, M.J.; Kuybeda, O.; Schauder, D.M.; Bartesaghi, A.; Frank, G.A.; Sapiro, G.; Milne, J.L.S.; Subramaniam, S. Structural Mechanism of Trimeric HIV-1 Envelope Glycoprotein Activation. PLoS Pathog. 2012, 8, e1002797. [CrossRef] [PubMed]

133. Qi, F.; Qian, S.; Zhang, S.; Zhang, Z. Single cell RNA sequencing of 13 human tissues identify cell types and receptors of human coronaviruses. Biochem. Biophys. Res. Commun. 2020. [CrossRef] [PubMed]

134. Wang, Q.; Zhang, Y.; Wu, L.; Niu, S.; Song, C.; Zhang, Z.; Lu, G.; Qiao, C.; Hu, Y.; Yuen, K.Y.; et al. Structural and Functional Basis of SARS-CoV-2 Entry by Using Human ACE2. Cell 2020. [CrossRef] [PubMed]

135. Cantuti-Castelvetri, L.; Ojha, R.; Pedro, L.D.; Djannatian, M.; Franz, J.; Kuivanen, S.; van der Meer, F.; Kallio, K.; Kaya, T.; Anastasina, M.; et al. Neuropilin-1 facilitates SARS-CoV-2 cell entry and infectivity. Science 2020. [CrossRef] [PubMed]

136. Daly, J.L.; Simonetti, B.; Klein, K.; Chen, K.E.; Williamson, M.K.; Antón-Plágaro, C.; Shoemark, D.K.; Simón-Gracia, L.; Bauer, M.; Hollandi, R.; et al. Neuropilin-1 is a host factor for SARS-CoV-2 infection. Science 2020. [CrossRef] [PubMed]

137. Wang, K.; Chen, W.; Zhang, Z.; Deng, Y.; Lian, J.Q.; Du, P.; Wei, D.; Zhang, Y.; Sun, X.X.; Gong, L.; et al. CD147-spike protein is a novel route for SARS-CoV-2 infection to host cells. Signal. Transduct. Target 2020, 5, 283. [CrossRef]

138. Chen, B. Molecular Mechanism of HIV-1 Entry. Trends Microbiol. 2019. [CrossRef]

139. Arthos, J.; Cicala, C.; Nawaz, F.; Byrareddy, S.N.; Villinger, F.; Santangelo, P.J.; Ansari, A.A.; Fauci, A.S. The Role of Integrin alpha4beta7 in HIV Pathogenesis and Treatment. Curr. HIV AIDS Rep. 2018, 15, 127-135. [CrossRef] [PubMed]

140. Ding, J.; Tasker, C.; Lespinasse, P.; Dai, J.; Fitzgerald-Bocarsly, P.; Lu, W.; Heller, D.; Chang, T.L. Integrin alpha4beta7 Expression Increases HIV Susceptibility in Activated Cervical CD4+ T Cells by an HIV Attachment-Independent Mechanism. J. Acquir. Immune Defic. Syndr. 2015, 69, 509-518. [CrossRef]

141. Bestle, D.; Heindl, M.R.; Limburg, H.; van Lam, T.; Pilgram, O.; Moulton, H.; Stein, D.A.; Hardes, K.; Eickmann, M.; Dolnik, O.; et al. TMPRSS2 and furin are both essential for proteolytic activation of SARS-CoV-2 in human airway cells. Life Sci. Alliance 2020, 3. [CrossRef] [PubMed]

142. Ou, T.; Mou, H.; Zhang, L.; Ojha, A.; Choe, H.; Farzan, M. Hydroxychloroquine-mediated inhibition of SARS-CoV-2 entry is attenuated by TMPRSS2. PLoS Pathog. 2021, 17, e1009212. [CrossRef] [PubMed]

143. Wang, Q.; Finzi, A.; Sodroski, J. The Conformational States of the HIV-1 Envelope Glycoproteins. Trends Microbiol. 2020, 28, 655-667. [CrossRef]

144. Shaik, M.M.; Peng, H.; Lu, J.; Rits-Volloch, S.; Xu, C.; Liao, M.; Chen, B. Structural basis of coreceptor recognition by HIV-1 envelope spike. Nature 2019, 565, 318-323. [CrossRef]

145. Bhatt, P.R.; Scaiola, A.; Loughran, G.; Leibundgut, M.; Kratzel, A.; Meurs, R.; Dreos, R.; O'Connor, K.M.; McMillan, A.; Bode, J.W.; et al. Structural basis of ribosomal frameshifting during translation of the SARS-CoV-2 RNA genome. Science 2021. [CrossRef]

146. Yan, L.; Yang, Y.; Li, M.; Zhang, Y.; Zheng, L.; Ge, J.; Huang, Y.; Liu, Z.; Wang, T.; Gao, S.; et al. Coupling of N7-methyltransferase and $3^{\prime}-5^{\prime}$ exoribonuclease with SARS-CoV-2 polymerase reveals mechanisms for capping and proofreading. Cell 2021. [CrossRef] [PubMed]

147. Craigie, R.; Bushman, F.D. HIV DNA integration. Cold Spring Harb. Perspect. Med. 2012, 2, a006890. [CrossRef]

148. Sundquist, W.I.; Kräusslich, H.G. HIV-1 Assembly, Budding, and Maturation. Cold Spring Harb. Perspect. Med. 2012,2, a006924.

149. Zila, V.; Margiotta, E.; Turoňová, B.; Müller, T.G.; Zimmerli, C.E.; Mattei, S.; Allegretti, M.; Börner, K.; Rada, J.; Müller, B.; et al. Cone-shaped HIV-1 capsids are transported through intact nuclear pores. Cell 2021. [CrossRef] [PubMed]

150. Aso, H.; Nagaoka, S.; Kawakami, E.; Ito, J.; Islam, S.; Tan, B.J.Y.; Nakaoka, S.; Ashizaki, K.; Shiroguchi, K.; Suzuki, Y.; et al. Multiomics Investigation Revealing the Characteristics of HIV-1-Infected Cells In Vivo. Cell Rep. 2020, 32, 107887. [CrossRef] [PubMed]

151. Dufour, C.; Gantner, P.; Fromentin, R.; Chomont, N. The multifaceted nature of HIV latency. J. Clin. Invest. 2020, 130, 3381-3390. [CrossRef]

152. Cohn, L.B.; Silva, I.T.; Oliveira, T.Y.; Rosales, R.A.; Parrish, E.H.; Learn, G.H.; Hahn, B.H.; Czartoski, J.L.; McElrath, M.J.; Lehmann, C.; et al. HIV-1 integration landscape during latent and active infection. Cell 2015, 160, 420-432. [CrossRef] [PubMed]

153. Siliciano, R.F.; Greene, W.C. HIV latency. Cold Spring Harb. Perspect. Med. 2011, 1, a007096. [CrossRef]

154. Sawicki, S.G.; Sawicki, D.L. Coronaviruses Use Discontinuous Extension for Synthesis of Subgenome-Length Negative Strands; Springer: Boston, MA, USA, 1995; Volume 380, pp. 499-506.

155. Viehweger, A.; Krautwurst, S.; Lamkiewicz, K.; Madhugiri, R.; Ziebuhr, J.; Hölzer, M.; Marz, M. Direct RNA nanopore sequencing of full-length coronavirus genomes provides novel insights into structural variants and enables modification analysis. Genome Res. 2019, 29, 1545-1554. [CrossRef] [PubMed]

156. Finkel, Y.; Mizrahi, O.; Nachshon, A.; Weingarten-Gabbay, S.; Morgenstern, D.; Yahalom-Ronen, Y.; Tamir, H.; Achdout, H.; Stein, D.; Israeli, O.; et al. The coding capacity of SARS-CoV-2. Nature 2021. [CrossRef] [PubMed]

157. Emery, A.; Swanstrom, R. HIV-1: To Splice or Not to Splice, That Is the Question. Viruses 2021, 13, 181. [CrossRef] [PubMed]

158. Parkin, N.T.; Chamorro, M.; Varmus, H.E. Human immunodeficiency virus type 1 gag-pol frameshifting is dependent on downstream mRNA secondary structure: Demonstration by expression in vivo. J. Virol. 1992, 66, 5147-5151. [CrossRef] [PubMed]

159. Snijder, E.J.; Limpens, R.W.A.L.; de Wilde, A.H.; de Jong, A.W.M.; Zevenhoven-Dobbe, J.C.; Maier, H.J.; Faas, F.F.G.A.; Koster, A.J.; Bárcena, M. A unifying structural and functional model of the coronavirus replication organelle: Tracking down RNA synthesis. PLoS Biol. 2020. [CrossRef] [PubMed]

160. Hu, W.S.; Hughes, S.H. HIV-1 reverse transcription. Cold Spring Harb. Perspect. Med. 2012. [CrossRef] 
161. Rasaiyaah, J.; Tan, C.P.; Fletcher, A.J.; Price, A.J.; Blondeau, C.; Hilditch, L.; Jacques, D.A.; Selwood, D.L.; James, L.C.; Noursadeghi, M.; et al. HIV-1 evades innate immune recognition through specific cofactor recruitment. Nature 2013. [CrossRef]

162. Jacks, T.; Power, M.D.; Masiarz, F.R.; Luciw, P.A.; Barr, P.J.; Varmus, H.E. Characterization of ribosomal frameshifting in HIV-1 gag-pol expression. Nature 1988. [CrossRef] [PubMed]

163. Dulude, D.; Berchiche, Y.A.; Gendron, K.; Brakier-Gingras, L.; Heveker, N. Decreasing the frameshift efficiency translates into an equivalent reduction of the replication of the human immunodeficiency virus type 1. Virology 2006. [CrossRef] [PubMed]

164. Hung, M.; Patel, P.; Davis, S.; Green, S.R. Importance of Ribosomal Frameshifting for Human Immunodeficiency Virus Type 1 Particle Assembly and Replication. J. Virol. 1998. [CrossRef] [PubMed]

165. Karacostas, V.; Wolffe, E.J.; Nagashima, K.; Gonda, M.A.; Moss, B. Overexpression of the hiv-1 gag-pol polyprotein results in intracellular activation of hiv-1 protease and inhibition of assembly and budding of virus-like particles. Virology 1993. [CrossRef] [PubMed]

166. Shehu-Xhilaga, M.; Crowe, S.M.; Mak, J. Maintenance of the Gag/Gag-Pol Ratio Is Important for Human Immunodeficiency Virus Type 1 RNA Dimerization and Viral Infectivity. J. Virol. 2001. [CrossRef] [PubMed]

167. Naamati, A.; Williamson, J.C.; Greenwood, E.J.; Marelli, S.; Lehner, P.J.; Matheson, N.J. Functional proteomic atlas of HIV infection in primary human CD4+ T cells. eLife 2019, 8. [CrossRef]

168. Matheson, N.J.; Sumner, J.; Wals, K.; Rapiteanu, R.; Weekes, M.P.; Vigan, R.; Weinelt, J.; Schindler, M.; Antrobus, R.; Costa, A.S.; et al. Cell Surface Proteomic Map of HIV Infection Reveals Antagonism of Amino Acid Metabolism by Vpu and Nef. Cell Host Microbe 2015, 18, 409-423. [CrossRef]

169. Ren, X.; Wen, W.; Fan, X.; Hou, W.; Su, B.; Cai, P.; Li, J.; Liu, Y.; Tang, F.; Zhang, F.; et al. COVID-19 immune features revealed by a large-scale single-cell transcriptome atlas. Cell 2021. [CrossRef] [PubMed]

170. Rendeiro, A.F.; Ravichandran, H.; Bram, Y.; Chandar, V.; Kim, J.; Meydan, C.; Park, J.; Foox, J.; Hether, T.; Warren, S.; et al. The spatial landscape of lung pathology during COVID-19 progression. Nature 2021. [CrossRef]

171. Sun, J.; Ye, F.; Wu, A.; Yang, R.; Pan, M.; Sheng, J.; Zhu, W.; Mao, L.; Wang, M.; Xia, Z.; et al. Comparative Transcriptome Analysis Reveals the Intensive Early Stage Responses of Host Cells to SARS-CoV-2 Infection. Front. Microbiol. 2020, 11, 593857. [CrossRef] [PubMed]

172. Lieberman, N.A.P.; Peddu, V.; Xie, H.; Shrestha, L.; Huang, M.L.; Mears, M.C.; Cajimat, M.N.; Bente, D.A.; Shi, P.Y.; Bovier, F.; et al. In vivo antiviral host transcriptional response to SARS-CoV-2 by viral load, sex, and age. PLoS Biol. 2020, 18, e3000849. [CrossRef]

173. Baggen, J.; Persoons, L.; Vanstreels, E.; Jansen, S.; Van Looveren, D.; Boeckx, B.; Geudens, V.; De Man, J.; Jochmans, D.; Wauters, J.; et al. Genome-wide CRISPR screening identifies TMEM106B as a proviral host factor for SARS-CoV-2. Nat. Genet. 2021. [CrossRef] [PubMed]

174. Bojkova, D.; Klann, K.; Koch, B.; Widera, M.; Krause, D.; Ciesek, S.; Cinatl, J.; Munch, C. Proteomics of SARS-CoV-2-infected host cells reveals therapy targets. Nature 2020, 583, 469-472. [CrossRef] [PubMed]

175. Gordon, D.E.; Hiatt, J.; Bouhaddou, M.; Rezelj, V.V.; Ulferts, S.; Braberg, H.; Jureka, A.S.; Obernier, K.; Guo, J.Z.; Batra, J.; et al. Comparative host-coronavirus protein interaction networks reveal pan-viral disease mechanisms. Science 2020, 370. [CrossRef]

176. Delorey, T.M.; Ziegler, C.G.K.; Heimberg, G.; Normand, R.; Yang, Y.; Segerstolpe, A.; Abbondanza, D.; Fleming, S.J.; Subramanian, A.; Montoro, D.T.; et al. COVID-19 tissue atlases reveal SARS-CoV-2 pathology and cellular targets. Nature 2021. [CrossRef]

177. Melms, J.C.; Biermann, J.; Huang, H.; Wang, Y.; Nair, A.; Tagore, S.; Katsyv, I.; Rendeiro, A.F.; Amin, A.D.; Schapiro, D.; et al. A molecular single-cell lung atlas of lethal COVID-19. Nature 2021. [CrossRef] [PubMed]

178. Schmidt, N.; Lareau, C.A.; Keshishian, H.; Ganskih, S.; Schneider, C.; Hennig, T.; Melanson, R.; Werner, S.; Wei, Y.; Zimmer, M.; et al. The SARS-CoV-2 RNA-protein interactome in infected human cells. Nat. Microbiol. 2020. [CrossRef]

179. Flynn, R.A.; Belk, J.A.; Qi, Y.; Yasumoto, Y.; Wei, J.; Alfajaro, M.M.; Shi, Q.; Mumbach, M.R.; Limaye, A.; DeWeirdt, P.C.; et al. Discovery and functional interrogation of SARS-CoV-2 RNA-host protein interactions. Cell 2021. [CrossRef]

180. Kamel, W.; Noerenberg, M.; Cerikan, B.; Chen, H.; Järvelin, A.I.; Kammoun, M.; Lee, J.Y.; Shuai, N.; Garcia-Moreno, M.; Andrejeva, A.; et al. Global analysis of protein-RNA interactions in SARS-CoV-2 infected cells reveals key regulators of infection. Mol. Cell 2021. [CrossRef]

181. Babé, L.M.; Craik, C.S. Viral proteases: Evolution of diverse structural motifs to optimize function. Cell 1997, 91, 427-430. [CrossRef]

182. Klemm, T.; Ebert, G.; Calleja, D.J.; Allison, C.C.; Richardson, L.W.; Bernardini, J.P.; Lu, B.G.C.; Kuchel, N.W.; Grohmann, C.; Shibata, Y.; et al. Mechanism and inhibition of the papain-like protease, PLpro, of SARS-CoV-2. EMBO J. 2020, 39 , e106275. [CrossRef]

183. Thiel, V.; Ivanov, K.A.; Putics, Á.; Hertzig, T.; Schelle, B.; Bayer, S.; Weißbrich, B.; Snijder, E.J.; Rabenau, H.; Doerr, H.W.; et al. Mechanisms and Enzymes Involved in SARS Coronavirus Genome Expression. J. General. Virol. 2003, 84, 2305-2315. [CrossRef]

184. Günther, S.; Reinke, P.Y.A.; Fernández-García, Y.; Lieske, J.; Lane, T.J.; Ginn, H.M.; Koua, F.H.M.; Ehrt, C.; Ewert, W.; Oberthuer, D.; et al. X-ray screening identifies active site and allosteric inhibitors of SARS-CoV-2 main protease. Science 2021. [CrossRef]

185. Lee, S.K.; Potempa, M.; Swanstrom, R. The Choreography of HIV-1 Proteolytic Processing and Virion Assembly. J. Biol. Chem. 2012, 287, 40867-40874. [CrossRef] [PubMed]

186. Kleinpeter, A.B.; Freed, E.O. HIV-1 maturation: Lessons learned from inhibitors. Viruses 2020, 12, 940. [CrossRef] [PubMed]

187. Freed, E.O. HIV-1 assembly, release and maturation. Nat. Rev. Microbiol. 2015, 13, 484-496. [CrossRef] 
188. Coutard, B.; Valle, C.; de Lamballerie, X.; Canard, B.; Seidah, N.G.; Decroly, E. The spike glycoprotein of the new coronavirus 2019-nCoV contains a furin-like cleavage site absent in CoV of the same clade. Antivir. Res. 2020, 176, 104742. [CrossRef]

189. Hoffmann, M.; Kleine-Weber, H.; Pöhlmann, S. A Multibasic Cleavage Site in the Spike Protein of SARS-CoV-2 Is Essential for Infection of Human Lung Cells. Mol. Cell 2020, 78, 779-784.e5. [CrossRef]

190. Klimstra, W.B.; Tilston-Lunel, N.L.; Nambulli, S.; Boslett, J.; McMillen, C.M.; Gilliland, T.; Dunn, M.D.; Sun, C.; Wheeler, S.E.; Wells, A.; et al. SARS-CoV-2 growth, furin-cleavage-site adaptation and neutralization using serum from acutely infected hospitalized COVID-19 patients. J. Gen. Virol. 2020, 101, 1156-1169. [CrossRef]

191. Lau, S.-Y.; Wang, P.; Mok, B.W.-Y.; Zhang, A.J.; Chu, H.; Lee, A.C.-Y.; Deng, S.; Chen, P.; Chan, K.-H.; Song, W.; et al. Attenuated SARS-CoV-2 variants with deletions at the S1/S2 junction. Emerg. Microbes Infect. 2020, 9, 837-842. [CrossRef]

192. Fenouillet, E.; Gluckman, J.C. Immunological analysis of human immunodeficiency virus type 1 envelope glycoprotein proteolytic cleavage. Virology 1992, 187, 825-828. [CrossRef]

193. Hallenberger, S.; Bosch, V.; Angliker, H.; Shaw, E.; Klenk, H.D.; Garten, W. Inhibition of furin-mediated cleavage activation of HIV-1 glycoprotein gpl60. Nature 1992, 360, 358-361. [CrossRef] [PubMed]

194. Miranda, L.; Wolf, J.; Pichuantes, S.; Duke, R.; Pranzusoff, A. Isolation of the human PC6 gene encoding the putative host protease for HIV-1 gp160 processing in CD4+ T lymphocytes. Proc. Natl. Acad. Sci. USA 1996, 93, 7695-7700. [CrossRef] [PubMed]

195. Bosch, V.; Pawlita, M. Mutational analysis of the human immunodeficiency virus type 1 env gene product proteolytic cleavage site. J. Virol. 1990, 64, 2337-2344. [CrossRef] [PubMed]

196. Herrera, C.; Klasse, P.J.; Michael, E.; Kake, S.; Barnes, K.; Kibler, C.W.; Campbell-Gardener, L.; Si, Z.; Sodroski, J.; Moore, J.P.; et al. The impact of envelope glycoprotein cleavage on the antigenicity, infectivity, and neutralization sensitivity of Env-pseudotyped human immunodeficiency virus type 1 particles. Virology 2005, 338, 154-172. [CrossRef] [PubMed]

197. McCune, J.M.; Rabin, L.B.; Feinberg, M.B.; Lieberman, M.; Kosek, J.C.; Reyes, G.R.; Weissman, I.L. Endoproteolytic cleavage of gp160 is required for the activation of human immunodeficiency virus. Cell 1988, 53, 55-67. [CrossRef]

198. Pancera, M.; Wyatt, R. Selective recognition of oligomeric HIV-1 primary isolate envelope glycoproteins by potently neutralizing ligands requires efficient precursor cleavage. Virology 2005, 332, 145-156. [CrossRef]

199. Tomaras, G.D.; Plotkin, S.A. Complex immune correlates of protection in HIV-1 vaccine efficacy trials. Immunol. Rev. 2017, 275, 245-261. [CrossRef]

200. Overbaugh, J.; Morris, L. The Antibody Response against HIV-1. Cold Spring Harb. Perspect. Med. 2012, 2, a007039. [CrossRef]

201. Gray, E.S.; Moore, P.L.; Choge, I.A.; Decker, J.M.; Bibollet-Ruche, F.; Li, H.; Leseka, N.; Treurnicht, F.; Mlisana, K.; Shaw, G.M.; et al. Neutralizing antibody responses in acute human immunodeficiency virus type 1 subtype C infection. J. Virol. 2007, 81, 6187-6196. [CrossRef]

202. Tomaras, G.D.; Haynes, B.F. HIV-1-specific antibody responses during acute and chronic HIV-1 infection. Curr. Opin. HIV AIDS 2009, 4, 373-379. [CrossRef]

203. Burton, D.R.; Mascola, J.R. Antibody responses to envelope glycoproteins in HIV-1 infection. Nat. Immunol. 2015, 16, 571-576. [CrossRef] [PubMed]

204. Piantadosi, A.; Panteleeff, D.; Blish, C.A.; Baeten, J.M.; Jaoko, W.; McClelland, R.S.; Overbaugh, J. Breadth of neutralizing antibody response to human immunodeficiency virus type 1 is affected by factors early in infection but does not influence disease progression. J. Virol. 2009, 83, 10269-10274. [CrossRef]

205. Gray, E.S.; Madiga, M.C.; Hermanus, T.; Moore, P.L.; Wibmer, C.K.; Tumba, N.L.; Werner, L.; Mlisana, K.; Sibeko, S.; Williamson, C.; et al. The neutralization breadth of HIV-1 develops incrementally over four years and is associated with CD4+ T cell decline and high viral load during acute infection. J. Virol. 2011, 85, 4828-4840. [CrossRef] [PubMed]

206. Doria-Rose, N.A. HIV neutralizing antibodies: Clinical correlates and implications for vaccines. J. Infect. Dis. 2010, 201, 981-983. [CrossRef] [PubMed]

207. Stamatatos, L.; Pancera, M.; McGuire, A.T. Germline-targeting immunogens. Immunol. Rev. 2017, 275, 203-216. [CrossRef] [PubMed]

208. Balazs, A.B.; Ouyang, Y.; Hong, C.M.; Chen, J.; Nguyen, S.M.; Rao, D.S.; An, D.S.; Baltimore, D. Vectored immunoprophylaxis protects humanized mice from mucosal HIV transmission. Nat. Med. 2014, 20, 296-300. [CrossRef]

209. Hessell, A.J.; Jaworski, J.P.; Epson, E.; Matsuda, K.; Pandey, S.; Kahl, C.; Reed, J.; Sutton, W.F.; Hammond, K.B.; Cheever, T.A.; et al. Early short-term treatment with neutralizing human monoclonal antibodies halts SHIV infection in infant macaques. Nat. Med. 2016, 22, 362-368. [CrossRef]

210. Morris, L.; Mkhize, N.N. Prospects for passive immunity to prevent HIV infection. PLoS Med. 2017, 14, e1002436. [CrossRef] [PubMed]

211. Corey, L.; Gilbert, P.B.; Juraska, M.; Montefiori, D.C.; Morris, L.; Karuna, S.T.; Edupuganti, S.; Mgodi, N.M.; de Camp, A.C.; Rudnicki, E.; et al. Two Randomized Trials of Neutralizing Antibodies to Prevent HIV-1 Acquisition. N. Engl. J. Med. 2021, 384, 1003-1014. [CrossRef] [PubMed]

212. Baden, L.R.; El Sahly, H.M.; Essink, B.; Kotloff, K.; Frey, S.; Novak, R.; Diemert, D.; Spector, S.A.; Rouphael, N.; Creech, C.B.; et al. Efficacy and Safety of the mRNA-1273 SARS-CoV-2 Vaccine. N. Engl. J. Med. 2021, 384, 403-416. [CrossRef]

213. Polack, F.P.; Thomas, S.J.; Kitchin, N.; Absalon, J.; Gurtman, A.; Lockhart, S.; Perez, J.L.; Perez Marc, G.; Moreira, E.D.; Zerbini, C.; et al. Safety and Efficacy of the BNT162b2 mRNA Covid-19 Vaccine. N. Engl. J. Med. 2020, 383, 2603-2615. [CrossRef] [PubMed] 
214. Kamps, B.S.; Hoffmann, C. COVID Reference ENG 2021.6, 6th Ed.; Camp, C.-E.R., Ed.; Springer: Berlin/Heidelberg, Germany, 2021.

215. Lumley, S.F.; O’Donnell, D.; Stoesser, N.E.; Matthews, P.C.; Howarth, A.; Hatch, S.B.; Marsden, B.D.; Cox, S.; James, T.; Warren, F.; et al. Antibody Status and Incidence of SARS-CoV-2 Infection in Health Care Workers. N. Engl. J. Med. 2020. [CrossRef]

216. Courtney, C.R.; Mayr, L.; Nanfack, A.J.; Banin, A.N.; Tuen, M.; Pan, R.; Jiang, X.; Kong, X.P.; Kirkpatrick, A.R.; Bruno, D.; et al. Contrasting antibody responses to intrasubtype superinfection with CRF02_AG. PLoS ONE 2017, 12, e0173705. [CrossRef]

217. Redd, A.D.; Quinn, T.C.; Tobian, A.A. Frequency and implications of HIV superinfection. Lancet Infect. Dis. 2013, 13, 622-628. [CrossRef]

218. Piantadosi, A.; Chohan, B.; Chohan, V.; McClelland, R.S.; Overbaugh, J. Chronic HIV-1 infection frequently fails to protect against superinfection. PLoS Pathog. 2007, 3, e177. [CrossRef]

219. Montefiori, D.C.; Karnasuta, C.; Huang, Y.; Ahmed, H.; Gilbert, P.; de Souza, M.S.; McLinden, R.; Tovanabutra, S.; LaurenceChenine, A.; Sanders-Buell, E.; et al. Magnitude and breadth of the neutralizing antibody response in the RV144 and Vax003 HIV-1 vaccine efficacy trials. J. Infect. Dis. 2012, 206, 431-441. [CrossRef]

220. Haynes, B.F.; Gilbert, P.B.; McElrath, M.J.; Zolla-Pazner, S.; Tomaras, G.D.; Alam, S.M.; Evans, D.T.; Montefiori, D.C.; Karnasuta, C.; Sutthent, R.; et al. Immune-correlates analysis of an HIV-1 vaccine efficacy trial. N. Engl. J. Med. 2012, 366, 1275-1286. [CrossRef]

221. Sette, A.; Crotty, S. Adaptive immunity to SARS-CoV-2 and COVID-19. Cell 2021. [CrossRef] [PubMed]

222. Robbiani, D.F.; Gaebler, C.; Muecksch, F.; Lorenzi, J.C.C.; Wang, Z.; Cho, A.; Agudelo, M.; Barnes, C.O.; Gazumyan, A.; Finkin, S.; et al. Convergent antibody responses to SARS-CoV-2 in convalescent individuals. Nature 2020, 584, 437-442. [CrossRef] [PubMed]

223. Clark, S.A.; Clark, L.E.; Pan, J.; Coscia, A.; McKay, L.G.A.; Shankar, S.; Johnson, R.I.; Brusic, V.; Choudhary, M.C.; Regan, J.; et al. SARS-CoV-2 evolution in an immunocompromised host reveals shared neutralization escape mechanisms. Cell 2021. [CrossRef]

224. Harvey, R.A.; Rassen, J.A.; Kabelac, C.A.; Turenne, W.; Leonard, S.; Klesh, R.; Meyer, W.A., 3rd; Kaufman, H.W.; Anderson, S.; Cohen, O.; et al. Association of SARS-CoV-2 Seropositive Antibody Test with Risk of Future Infection. JAMA Intern. Med. 2021. [CrossRef]

225. Hansen, C.H.; Michlmayr, D.; Gubbels, S.M.; Mølbak, K.; Ethelberg, S. Assessment of protection against reinfection with SARS-CoV-2 among 4 million PCR-tested individuals in Denmark in 2020: A population-level observational study. Lancet 2021. [CrossRef]

226. Hall, V.J.; Foulkes, S.; Charlett, A.; Atti, A.; Monk, E.J.M.; Simmons, R.; Wellington, E.; Cole, M.J.; Saei, A.; Oguti, B.; et al. SARS-CoV-2 infection rates of antibody-positive compared with antibody-negative health-care workers in England: A large, multicentre, prospective cohort study (SIREN). Lancet 2021, 397, 1459-1469. [CrossRef]

227. Letizia, A.G.; Ge, Y.; Vangeti, S.; Goforth, C.; Weir, D.L.; Kuzmina, N.A.; Balinsky, C.A.; Chen, H.W.; Ewing, D.; Soares-Schanoski, A.; et al. SARS-CoV-2 seropositivity and subsequent infection risk in healthy young adults: A prospective cohort study. Lancet Respir. Med. 2021. [CrossRef]

228. Leidi, A.; Koegler, F.; Dumont, R.; Dubos, R.; Zaballa, M.-E.; Piumatti, G.; Coen, M.; Berner, A.; Darbellay Farhoumand, P.; Vetter, P.; et al. Risk of reinfection after seroconversion to SARS-CoV-2: A population-based propensity-score matched cohort study. Clin. Infect. Dis. 2021. [CrossRef]

229. Vitale, J.; Mumoli, N.; Clerici, P.; De Paschale, M.; Evangelista, I.; Cei, M.; Mazzone, A. Assessment of SARS-CoV-2 Reinfection 1 Year After Primary Infection in a Population in Lombardy, Italy. JAMA Intern. Med. 2021. [CrossRef] [PubMed]

230. Dagan, N.; Barda, N.; Kepten, E.; Miron, O.; Perchik, S.; Katz, M.A.; Hernan, M.A.; Lipsitch, M.; Reis, B.; Balicer, R.D. BNT162b2 mRNA Covid-19 Vaccine in a Nationwide Mass Vaccination Setting. N. Engl. J. Med. 2021. [CrossRef]

231. Daniel, W.; Nivet, M.; Warner, J.; Podolsky, D.K. Early Evidence of the Effect of SARS-CoV-2 Vaccine at One Medical Center. N. Engl. J. Med. 2021. [CrossRef]

232. Thompson, M.G.; Burgess, J.L.; Naleway, A.L.; Tyner, H.L.; Yoon, S.K.; Meece, J.; Olsho, L.E.W.; Caban-Martinez, A.J.; Fowlkes, A.; Lutrick, K.; et al. Interim Estimates of Vaccine Effectiveness of BNT162b2 and mRNA-1273 COVID-19 Vaccines in Preventing SARS-CoV-2 Infection Among Health Care Personnel, First Responders, and Other Essential and Frontline Workers-Eight, U.S. Locations, December 2020-March 2021. MMWR Morb. Mortal Wkly. Rep. 2021, 70, 495-500. [CrossRef] [PubMed]

233. Rossman, H.; Shilo, S.; Meir, T.; Gorfine, M.; Shalit, U.; Segal, E. COVID-19 dynamics after a national immunization program in Israel. Nat. Med. 2021. [CrossRef]

234. Haas, E.J.; Angulo, F.J.; McLaughlin, J.M.; Anis, E.; Singer, S.R.; Khan, F.; Brooks, N.; Smaja, M.; Mircus, G.; Pan, K.; et al. Impact and effectiveness of mRNA BNT162b2 vaccine against SARS-CoV-2 infections and COVID-19 cases, hospitalisations, and deaths following a nationwide vaccination campaign in Israel: An observational study using national surveillance data. Lancet 2021, 397, 1819-1829. [CrossRef]

235. Chodick, G.; Tene, L.; Rotem, R.S.; Patalon, T.; Gazit, S.; Ben-Tov, A.; Weil, C.; Goldshtein, I.; Twig, G.; Cohen, D.; et al. The effectiveness of the TWO-DOSE BNT162b2 vaccine: Analysis of real-world data. Clin. Infect. Dis 2021. [CrossRef] [PubMed]

236. Pilishvili, T.; Fleming-Dutra, K.E.; Farrar, J.L.; Gierke, R.; Mohr, N.M.; Talan, D.A.; Krishnadasan, A.; Harland, K.K.; Smithline, H.A.; Hou, P.C.; et al. Interim Estimates of Vaccine Effectiveness of Pfizer-BioNTech and Moderna COVID-19 Vaccines Among Health Care Personnel-33 U.S. Sites, January-March 2021. MMWR Morb. Mortal Wkly. Rep. 2021, 70, 753-758. [CrossRef] 
237. Khoury, D.S.; Cromer, D.; Reynaldi, A.; Schlub, T.E.; Wheatley, A.K.; Juno, J.A.; Subbarao, K.; Kent, S.J.; Triccas, J.A.; Davenport, M.P. Neutralizing antibody levels are highly predictive of immune protection from symptomatic SARS-CoV-2 infection. Nat. Med. 2021. [CrossRef]

238. Chandrashekar, A.; Liu, J.; Martinot, A.J.; McMahan, K.; Mercado, N.B.; Peter, L.; Tostanoski, L.H.; Yu, J.; Maliga, Z.; Nekorchuk, M.; et al. SARS-CoV-2 infection protects against rechallenge in rhesus macaques. Science 2020, 369, 812-817. [CrossRef]

239. Tauzin, A.; Nayrac, M.; Benlarbi, M.; Gong, S.Y.; Gasser, R.; Beaudoin-Bussières, G.; Brassard, N.; Laumaea, A.; Vézina, D.; Prévost, J.; et al. A single BNT162b2 mRNA dose elicits antibodies with Fc-mediated effector functions and boost pre-existing humoral and T cell responses. bioRxiv 2021. [CrossRef]

240. Garrett, M.E.; Galloway, J.; Chu, H.Y.; Itell, H.L.; Stoddard, C.I.; Wolf, C.R.; Logue, J.K.; McDonald, D.; Weight, H.; Matsen, F.A.t.; et al. High-resolution profiling of pathways of escape for SARS-CoV-2 spike-binding antibodies. Cell 2021, 184, 2927-2938.e11. [CrossRef]

241. Voss, W.N.; Hou, Y.J.; Johnson, N.V.; Delidakis, G.; Kim, J.E.; Javanmardi, K.; Horton, A.P.; Bartzoka, F.; Paresi, C.J.; Tanno, Y.; et al. Prevalent, protective, and convergent IgG recognition of SARS-CoV-2 non-RBD spike epitopes. Science 2021. [CrossRef]

242. Anand, S.P.; Prevost, J.; Nayrac, M.; Beaudoin-Bussieres, G.; Benlarbi, M.; Gasser, R.; Brassard, N.; Laumaea, A.; Gong, S.Y.; Bourassa, C.; et al. Longitudinal analysis of humoral immunity against SARS-CoV-2 Spike in convalescent individuals up to 8 months post-symptom onset. bioRxiv 2021. [CrossRef]

243. Vanshylla, K.; Di Cristanziano, V.; Kleipass, F.; Dewald, F.; Schommers, P.; Gieselmann, L.; Gruell, H.; Schlotz, M.; Ercanoglu, M.S.; Stumpf, R.; et al. Kinetics and correlates of the neutralizing antibody response to SARS-CoV-2. bioRxiv 2021. [CrossRef]

244. Dan, J.M.; Mateus, J.; Kato, Y.; Hastie, K.M.; Yu, E.D.; Faliti, C.E.; Grifoni, A.; Ramirez, S.I.; Haupt, S.; Frazier, A.; et al. Immunological memory to SARS-CoV-2 assessed for up to 8 months after infection. Science 2021, 371. [CrossRef] [PubMed]

245. Wajnberg, A.; Amanat, F.; Firpo, A.; Altman, D.R.; Bailey, M.J.; Mansour, M.; McMahon, M.; Meade, P.; Mendu, D.R.; Muellers, K.; et al. Robust neutralizing antibodies to SARS-CoV-2 infection persist for months. Science 2020, 370, 1227-1230. [CrossRef] [PubMed]

246. Gaebler, C.; Wang, Z.; Lorenzi, J.C.C.; Muecksch, F.; Finkin, S.; Tokuyama, M.; Cho, A.; Jankovic, M.; Schaefer-Babajew, D.; Oliveira, T.Y.; et al. Evolution of antibody immunity to SARS-CoV-2. Nature 2021. [CrossRef]

247. Garcia-Beltran, W.F.; Lam, E.C.; Astudillo, M.G.; Yang, D.; Miller, T.E.; Feldman, J.; Hauser, B.M.; Caradonna, T.M.; Clayton, K.L.; Nitido, A.D.; et al. COVID-19-neutralizing antibodies predict disease severity and survival. Cell 2021, 184, 476-488.e11. [CrossRef] [PubMed]

248. Roltgen, K.; Powell, A.E.; Wirz, O.F.; Stevens, B.A.; Hogan, C.A.; Najeeb, J.; Hunter, M.; Wang, H.; Sahoo, M.K.; Huang, C.; et al. Defining the features and duration of antibody responses to SARS-CoV-2 infection associated with disease severity and outcome. Sci. Immunol. 2020, 5. [CrossRef]

249. Piccoli, L.; Park, Y.J.; Tortorici, M.A.; Czudnochowski, N.; Walls, A.C.; Beltramello, M.; Silacci-Fregni, C.; Pinto, D.; Rosen, L.E.; Bowen, J.E.; et al. Mapping Neutralizing and Immunodominant Sites on the SARS-CoV-2 Spike Receptor-Binding Domain by Structure-Guided High-Resolution Serology. Cell 2020, 183, 1024-1042.e21. [CrossRef]

250. Legros, V.; Denolly, S.; Vogrig, M.; Boson, B.; Siret, E.; Rigaill, J.; Pillet, S.; Grattard, F.; Gonzalo, S.; Verhoeven, P.; et al. A longitudinal study of SARS-CoV-2-infected patients reveals a high correlation between neutralizing antibodies and COVID-19 severity. Cell Mol. Immunol. 2021, 18, 318-327. [CrossRef] [PubMed]

251. Zohar, T.; Loos, C.; Fischinger, S.; Atyeo, C.; Wang, C.; Slein, M.D.; Burke, J.; Yu, J.; Feldman, J.; Hauser, B.M.; et al. Compromised Humoral Functional Evolution Tracks with SARS-CoV-2 Mortality. Cell 2020, 183, 1508-1519.e12. [CrossRef]

252. Dispinseri, S.; Secchi, M.; Pirillo, M.F.; Tolazzi, M.; Borghi, M.; Brigatti, C.; De Angelis, M.L.; Baratella, M.; Bazzigaluppi, E.; Venturi, G.; et al. Neutralizing antibody responses to SARS-CoV-2 in symptomatic COVID-19 is persistent and critical for survival. Nat. Commun. 2021, 12, 2670. [CrossRef] [PubMed]

253. Lucas, C.; Klein, J.; Sundaram, M.E.; Liu, F.; Wong, P.; Silva, J.; Mao, T.; Oh, J.E.; Mohanty, S.; Huang, J.; et al. Delayed production of neutralizing antibodies correlates with fatal COVID-19. Nat. Med. 2021. [CrossRef]

254. Asarnow, D.; Wang, B.; Lee, W.H.; Hu, Y.; Huang, C.W.; Faust, B.; Ng, P.M.L.; Ngoh, E.Z.X.; Bohn, M.; Bulkley, D.; et al. Structural insight into SARS-CoV-2 neutralizing antibodies and modulation of syncytia. Cell 2021. [CrossRef] [PubMed]

255. Liu, Y.; Soh, W.T.; Kishikawa, J.-i.; Hirose, M.; Nakayama, E.E.; Li, S.; Sasai, M.; Suzuki, T.; Tada, A.; Arakawa, A.; et al. An infectivity-enhancing site on the SARS-CoV-2 spike protein targeted by antibodies. Cell 2021. [CrossRef]

256. Jaume, M.; Yip, M.S.; Cheung, C.Y.; Leung, H.L.; Li, P.H.; Kien, F.; Dutry, I.; Callendret, B.; Escriou, N.; Altmeyer, R.; et al Anti-severe acute respiratory syndrome coronavirus spike antibodies trigger infection of human immune cells via a pH- and cysteine protease-independent FcgammaR pathway. J. Virol. 2011, 85, 10582-10597. [CrossRef] [PubMed]

257. Wan, Y.; Shang, J.; Sun, S.; Tai, W.; Chen, J.; Geng, Q.; He, L.; Chen, Y.; Wu, J.; Shi, Z.; et al. Molecular Mechanism for Antibody-Dependent Enhancement of Coronavirus Entry. J. Virol. 2020, 94. [CrossRef]

258. Hachim, A.; Kavian, N.; Cohen, C.A.; Chin, A.W.H.; Chu, D.K.W.; Mok, C.K.P.; Tsang, O.T.Y.; Yeung, Y.C.; Perera, R.; Poon, L.L.M.; et al. ORF8 and ORF3b antibodies are accurate serological markers of early and late SARS-CoV-2 infection. Nat. Immunol. 2020, 21, 1293-1301. [CrossRef]

259. Atyeo, C.; Fischinger, S.; Zohar, T.; Slein, M.D.; Burke, J.; Loos, C.; McCulloch, D.J.; Newman, K.L.; Wolf, C.; Yu, J.; et al. Distinct Early Serological Signatures Track with SARS-CoV-2 Survival. Immunity 2020, 53, 524-532.e4. [CrossRef] 
260. Russell, M.W.; Moldoveanu, Z.; Ogra, P.L.; Mestecky, J. Mucosal Immunity in COVID-19: A Neglected but Critical Aspect of SARS-CoV-2 Infection. Front. Immunol. 2020, 11, 611337. [CrossRef]

261. Cervia, C.; Nilsson, J.; Zurbuchen, Y.; Valaperti, A.; Schreiner, J.; Wolfensberger, A.; Raeber, M.E.; Adamo, S.; Emmenegger, M.; Hasler, S.; et al. Systemic and mucosal antibody secretion specific to SARS-CoV-2 during mild versus severe COVID-19. bioRxiv 2020. [CrossRef]

262. Isho, B.; Abe, K.T.; Zuo, M.; JAMAl, A.J.; Rathod, B.; Wang, J.H.; Li, Z.; Chao, G.; Rojas, O.L.; Bang, Y.M.; et al. Persistence of serum and saliva antibody responses to SARS-CoV-2 spike antigens in COVID-19 patients. Sci. Immunol. 2020, 5. [CrossRef]

263. Lavine, J.S.; Bjornstad, O.N.; Antia, R. Immunological characteristics govern the transition of COVID-19 to endemicity. Science 2021, 371, 741-745. [CrossRef] [PubMed]

264. Zohar, T.; Alter, G. Dissecting antibody-mediated protection against SARS-CoV-2. Nat. Rev. Immunol. 2020, 20, 392-394. [CrossRef]

265. Forthal, D.N. Functions of Antibodies. Microbiol. Spectr. 2014, 2, 1-17. [CrossRef] [PubMed]

266. Forthal, D.N.; Finzi, A. Antibody-dependent cellular cytotoxicity in HIV infection. AIDS 2018, 32, 2439-2451. [CrossRef] [PubMed]

267. Tay, M.Z.; Wiehe, K.; Pollara, J. Antibody-Dependent Cellular Phagocytosis in Antiviral Immune Responses. Front. Immunol. 2019, 10, 332. [CrossRef] [PubMed]

268. Wang, P.; Gajjar, M.R.; Yu, J.; Padte, N.N.; Gettie, A.; Blanchard, J.L.; Russell-Lodrigue, K.; Liao, L.E.; Perelson, A.S.; Huang, Y.; et al. Quantifying the contribution of Fc-mediated effector functions to the antiviral activity of anti-HIV-1 IgG1 antibodies in vivo. Proc. Natl. Acad. Sci. USA 2020, 117, 18002-18009. [CrossRef]

269. Hessell, A.J.; Hangartner, L.; Hunter, M.; Havenith, C.E.; Beurskens, F.J.; Bakker, J.M.; Lanigan, C.M.; Landucci, G.; Forthal, D.N.; Parren, P.W.; et al. Fc receptor but not complement binding is important in antibody protection against HIV. Nature 2007, 449, 101-104. [CrossRef] [PubMed]

270. Ackerman, M.E.; Mikhailova, A.; Brown, E.P.; Dowell, K.G.; Walker, B.D.; Bailey-Kellogg, C.; Suscovich, T.J.; Alter, G. Polyfunctional HIV-Specific Antibody Responses Are Associated with Spontaneous HIV Control. PLoS Pathog. 2016, 12, e1005315. [CrossRef]

271. Tuen, M.; Bimela, J.S.; Banin, A.N.; Ding, S.; Harkins, G.W.; Weiss, S.; Itri, V.; Durham, A.R.; Porcella, S.F.; Soni, S.; et al. Immune Correlates of Disease Progression in Linked HIV-1 Infection. Front. Immunol. 2019, 10, 1062. [CrossRef]

272. Liao, H.X.; Bonsignori, M.; Alam, S.M.; McLellan, J.S.; Tomaras, G.D.; Moody, M.A.; Kozink, D.M.; Hwang, K.K.; Chen, X.; Tsao, C.Y.; et al. Vaccine induction of antibodies against a structurally heterogeneous site of immune pressure within HIV-1 envelope protein variable regions 1 and 2. Immunity 2013, 38, 176-186. [CrossRef] [PubMed]

273. Tomaras, G.D.; Ferrari, G.; Shen, X.; Alam, S.M.; Liao, H.X.; Pollara, J.; Bonsignori, M.; Moody, M.A.; Fong, Y.; Chen, X.; et al. Vaccine-induced plasma IgA specific for the C1 region of the HIV-1 envelope blocks binding and effector function of IgG. Proc. Natl. Acad. Sci. USA 2013, 110, 9019-9024. [CrossRef]

274. Gottardo, R.; Bailer, R.T.; Korber, B.T.; Gnanakaran, S.; Phillips, J.; Shen, X.; Tomaras, G.D.; Turk, E.; Imholte, G.; Eckler, L.; et al. Plasma IgG to linear epitopes in the V2 and V3 regions of HIV-1 gp120 correlate with a reduced risk of infection in the RV144 vaccine efficacy trial. PLoS ONE 2013, 8, e75665. [CrossRef] [PubMed]

275. Li, S.S.; Gilbert, P.B.; Tomaras, G.D.; Kijak, G.; Ferrari, G.; Thomas, R.; Pyo, C.W.; Zolla-Pazner, S.; Montefiori, D.; Liao, H.X.; et al. FCGR2C polymorphisms associate with HIV-1 vaccine protection in RV144 trial. J. Clin. Invest. 2014, 124, 3879-3890. [CrossRef] [PubMed]

276. Bruel, T.; Guivel-Benhassine, F.; Amraoui, S.; Malbec, M.; Richard, L.; Bourdic, K.; Donahue, D.A.; Lorin, V.; Casartelli, N.; Noel, N.; et al. Elimination of HIV-1-infected cells by broadly neutralizing antibodies. Nat. Commun. 2016, 7, 10844. [CrossRef]

277. Bruel, T.; Guivel-Benhassine, F.; Lorin, V.; Lortat-Jacob, H.; Baleux, F.; Bourdic, K.; Noel, N.; Lambotte, O.; Mouquet, H.; Schwartz, O. Lack of ADCC Breadth of Human Nonneutralizing Anti-HIV-1 Antibodies. J. Virol. 2017, 91. [CrossRef]

278. Montefiori, D.C.; Filsinger Interrante, M.V.; Bell, B.N.; Rubio, A.A.; Joyce, J.G.; Shiver, J.W.; LaBranche, C.C.; Kim, P.S. The high-affinity immunoglobulin receptor FcgammaRI potentiates HIV-1 neutralization via antibodies against the gp41 N-heptad repeat. Proc. Natl. Acad. Sci. USA 2021, 118. [CrossRef]

279. Ren, Y.; Korom, M.; Truong, R.; Chan, D.; Huang, S.H.; Kovacs, C.C.; Benko, E.; Safrit, J.T.; Lee, J.; Garban, H.; et al. Susceptibility to Neutralization by Broadly Neutralizing Antibodies Generally Correlates with Infected Cell Binding for a Panel of Clade B HIV Reactivated from Latent Reservoirs. J. Virol 2018, 92. [CrossRef]

280. Von Bredow, B.; Arias, J.F.; Heyer, L.N.; Moldt, B.; Le, K.; Robinson, J.E.; Zolla-Pazner, S.; Burton, D.R.; Evans, D.T. Comparison of Antibody-Dependent Cell-Mediated Cytotoxicity and Virus Neutralization by HIV-1 Env-Specific Monoclonal Antibodies. J. Virol. 2016, 90, 6127-6139. [CrossRef]

281. Parsons, M.S.; Lee, W.S.; Kristensen, A.B.; Amarasena, T.; Khoury, G.; Wheatley, A.K.; Reynaldi, A.; Wines, B.D.; Hogarth, P.M.; Davenport, M.P.; et al. Fc-dependent functions are redundant to efficacy of anti-HIV antibody PGT121 in macaques. J. Clin. Invest. 2018. [CrossRef] [PubMed]

282. Von Bredow, B.; Andrabi, R.; Grunst, M.; Grandea, A.G., 3rd; Le, K.; Song, G.; Berndsen, Z.T.; Porter, K.; Pallesen, J.; Ward, A.B.; et al. Differences in the Binding Affinity of an HIV-1 V2 Apex-Specific Antibody for the SIVsmm/mac Envelope Glycoprotein Uncouple Antibody-Dependent Cellular Cytotoxicity from Neutralization. mBio 2019, 10. [CrossRef] [PubMed] 
283. Anand, S.P.; Grover, J.R.; Tolbert, W.D.; Prevost, J.; Richard, J.; Ding, S.; Baril, S.; Medjahed, H.; Evans, D.T.; Pazgier, M.; et al. Antibody-Induced Internalization of HIV-1 Env Proteins Limits Surface Expression of the Closed Conformation of Env. J. Virol. 2019, 93. [CrossRef] [PubMed]

284. Pollara, J.; Bonsignori, M.; Moody, M.A.; Pazgier, M.; Haynes, B.F.; Ferrari, G. Epitope specificity of human immunodeficiency virus-1 antibody dependent cellular cytotoxicity [ADCC] responses. Curr. HIV Res. 2013, 11, 378-387. [CrossRef] [PubMed]

285. Richard, J.; Prevost, J.; Alsahafi, N.; Ding, S.; Finzi, A. Impact of HIV-1 Envelope Conformation on ADCC Responses. Trends Microbiol. 2018, 26, 253-265. [CrossRef] [PubMed]

286. Richard, J.; Prevost, J.; Baxter, A.E.; von Bredow, B.; Ding, S.; Medjahed, H.; Delgado, G.G.; Brassard, N.; Sturzel, C.M.; Kirchhoff, F.; et al. Uninfected Bystander Cells Impact the Measurement of HIV-Specific Antibody-Dependent Cellular Cytotoxicity Responses. mBio 2018, 9. [CrossRef]

287. Chan, C.E.Z.; Seah, S.G.K.; Chye, D.H.; Massey, S.; Torres, M.; Lim, A.P.C.; Wong, S.K.K.; Neo, J.J.Y.; Wong, P.S.; Lim, J.H.; et al. The Fc-mediated effector functions of a potent SARS-CoV-2 neutralizing antibody, SC31, isolated from an early convalescent COVID-19 patient, are essential for the optimal therapeutic efficacy of the antibody. bioRxiv 2020. [CrossRef]

288. Dufloo, J.; Grzelak, L.; Staropoli, I.; Madec, Y.; Tondeur, L.; Anna, F.; Pelleau, S.; Wiedemann, A.; Planchais, C.; Buchrieser, J.; et al. Asymptomatic and symptomatic SARS-CoV-2 infections elicit polyfunctional antibodies. medRxiv 2020. [CrossRef]

289. Yu, J.; Tostanoski, L.H.; Peter, L.; Mercado, N.B.; McMahan, K.; Mahrokhian, S.H.; Nkolola, J.P.; Liu, J.; Li, Z.; Chandrashekar, A.; et al. DNA vaccine protection against SARS-CoV-2 in rhesus macaques. Science 2020, 369, 806-811. [CrossRef]

290. Schafer, A.; Muecksch, F.; Lorenzi, J.C.C.; Leist, S.R.; Cipolla, M.; Bournazos, S.; Schmidt, F.; Maison, R.M.; Gazumyan, A.; Martinez, D.R.; et al. Antibody potency, effector function, and combinations in protection and therapy for SARS-CoV-2 infection in vivo. J. Exp. Med. 2021, 218. [CrossRef]

291. Tortorici, M.A.; Beltramello, M.; Lempp, F.A.; Pinto, D.; Dang, H.V.; Rosen, L.E.; McCallum, M.; Bowen, J.; Minola, A.; Jaconi, S.; et al. Ultrapotent human antibodies protect against SARS-CoV-2 challenge via multiple mechanisms. Science 2020, 370, 950-957. [CrossRef]

292. Hie, B.; Zhong, E.D.; Berger, B.; Bryson, B. Learning the language of viral evolution and escape. Science 2021, 371, 284-288. [CrossRef] [PubMed]

293. Choi, B.; Choudhary, M.C.; Regan, J.; Sparks, J.A.; Padera, R.F.; Qiu, X.; Solomon, I.H.; Kuo, H.H.; Boucau, J.; Bowman, K.; et al. Persistence and Evolution of SARS-CoV-2 in an Immunocompromised Host. N. Engl. J. Med. 2020, 383, 2291-2293. [CrossRef] [PubMed]

294. Helleberg, M.; Niemann, C.U.; Moestrup, K.S.; Kirk, O.; Lebech, A.M.; Lane, C.; Lundgren, J. Persistent COVID-19 in an Immunocompromised Patient Temporarily Responsive to Two Courses of Remdesivir Therapy. J. Infect. Dis. 2020, 222, $1103-1107$. [CrossRef]

295. Kemp, S.A.; Collier, D.A.; Datir, R.P.; Ferreira, I.; Gayed, S.; Jahun, A.; Hosmillo, M.; Rees-Spear, C.; Mlcochova, P.; Lumb, I.U.; et al. SARS-CoV-2 evolution during treatment of chronic infection. Nature 2021. [CrossRef] [PubMed]

296. Reuken, P.A.; Stallmach, A.; Pletz, M.W.; Brandt, C.; Andreas, N.; Hahnfeld, S.; Loffler, B.; Baumgart, S.; Kamradt, T.; Bauer, M. Severe clinical relapse in an immunocompromised host with persistent SARS-CoV-2 infection. Leukemia 2021, -8. [CrossRef]

297. Avanzato, V.A.; Matson, M.J.; Seifert, S.N.; Pryce, R.; Williamson, B.N.; Anzick, S.L.; Barbian, K.; Judson, S.D.; Fischer, E.R.; Martens, C.; et al. Case Study: Prolonged Infectious SARS-CoV-2 Shedding from an Asymptomatic Immunocompromised Individual with Cancer. Cell 2020, 183, 1901-1912.e9. [CrossRef] [PubMed]

298. Moody, M.A.; Gao, F.; Gurley, T.C.; Amos, J.D.; Kumar, A.; Hora, B.; Marshall, D.J.; Whitesides, J.F.; Xia, S.M.; Parks, R.; et al. Strain-Specific V3 and CD4 Binding Site Autologous HIV-1 Neutralizing Antibodies Select Neutralization-Resistant Viruses. Cell Host Microbe 2015, 18, 354-362. [CrossRef]

299. Rong, R.; Li, B.; Lynch, R.M.; Haaland, R.E.; Murphy, M.K.; Mulenga, J.; Allen, S.A.; Pinter, A.; Shaw, G.M.; Hunter, E.; et al. Escape from autologous neutralizing antibodies in acute/early subtype C HIV-1 infection requires multiple pathways. PLoS Pathog. 2009, 5, e1000594. [CrossRef]

300. Ping, L.H.; Joseph, S.B.; Anderson, J.A.; Abrahams, M.R.; Salazar-Gonzalez, J.F.; Kincer, L.P.; Treurnicht, F.K.; Arney, L.; Ojeda, S.; Zhang, M.; et al. Comparison of viral Env proteins from acute and chronic infections with subtype $C$ human immunodeficiency virus type 1 identifies differences in glycosylation and CCR5 utilization and suggests a new strategy for immunogen design. J. Virol. 2013, 87, 7218-7233. [CrossRef]

301. Sagar, M.; Wu, X.; Lee, S.; Overbaugh, J. Human immunodeficiency virus type 1 V1-V2 envelope loop sequences expand and add glycosylation sites over the course of infection, and these modifications affect antibody neutralization sensitivity. J. Virol. 2006, 80, 9586-9598. [CrossRef]

302. Bailey, J.; Blankson, J.N.; Wind-Rotolo, M.; Siliciano, R.F. Mechanisms of HIV-1 escape from immune responses and antiretroviral drugs. Curr. Opin. Immunol. 2004, 16, 470-476. [CrossRef]

303. Wei, X.; Decker, J.M.; Wang, S.; Hui, H.; Kappes, J.C.; Wu, X.; Salazar-Gonzalez, J.F.; Salazar, M.G.; Kilby, J.M.; Saag, M.S.; et al. Antibody neutralization and escape by HIV-1. Nature 2003, 422, 307-312. [CrossRef]

304. Curlin, M.E.; Zioni, R.; Hawes, S.E.; Liu, Y.; Deng, W.; Gottlieb, G.S.; Zhu, T.; Mullins, J.I. HIV-1 envelope subregion length variation during disease progression. PLoS Pathog. 2010, 6, e1001228. [CrossRef] [PubMed] 
305. Van Gils, M.J.; Bunnik, E.M.; Boeser-Nunnink, B.D.; Burger, J.A.; Terlouw-Klein, M.; Verwer, N.; Schuitemaker, H. Longer V1V2 region with increased number of potential N-linked glycosylation sites in the HIV-1 envelope glycoprotein protects against HIV-specific neutralizing antibodies. J. Virol. 2011, 85, 6986-6995. [CrossRef] [PubMed]

306. Dingens, A.S.; Arenz, D.; Weight, H.; Overbaugh, J.; Bloom, J.D. An Antigenic Atlas of HIV-1 Escape from Broadly Neutralizing Antibodies Distinguishes Functional and Structural Epitopes. Immunity 2019, 50, 520-532.e3. [CrossRef]

307. Bonsignori, M.; Liao, H.X.; Gao, F.; Williams, W.B.; Alam, S.M.; Montefiori, D.C.; Haynes, B.F. Antibody-virus co-evolution in HIV infection: Paths for HIV vaccine development. Immunol. Rev. 2017, 275, 145-160. [CrossRef]

308. Doria-Rose, N.A.; Landais, E. Coevolution of HIV-1 and broadly neutralizing antibodies. Curr. Opin. HIV AIDS 2019, 14, 286-293. [CrossRef]

309. Burton, D.R.; Hangartner, L. Broadly Neutralizing Antibodies to HIV and Their Role in Vaccine Design. Annu. Rev. Immunol. 2016, 34, 635-659. [CrossRef] [PubMed]

310. Bai, H.; Li, Y.; Michael, N.L.; Robb, M.L.; Rolland, M. The breadth of HIV-1 neutralizing antibodies depends on the conservation of key sites in their epitopes. PLoS Comput. Biol. 2019, 15, e1007056. [CrossRef]

311. Caskey, M.; Klein, F.; Nussenzweig, M.C. Broadly neutralizing anti-HIV-1 monoclonal antibodies in the clinic. Nat. Med. 2019, 25, 547-553. [CrossRef]

312. McCoy, L.E. The expanding array of HIV broadly neutralizing antibodies. Retrovirology 2018, 15, 70. [CrossRef] [PubMed]

313. McCoy, L.E.; Burton, D.R. Identification and specificity of broadly neutralizing antibodies against HIV. Immunol. Rev. 2017, 275, 11-20. [CrossRef]

314. Jia, M.; Liberatore, R.A.; Guo, Y.; Chan, K.W.; Pan, R.; Lu, H.; Waltari, E.; Mittler, E.; Chandran, K.; Finzi, A.; et al. VSV-Displayed HIV-1 Envelope Identifies Broadly Neutralizing Antibodies Class-Switched to IgG and IgA. Cell Host Microbe 2020, 27, 963-975.e5. [CrossRef]

315. Kong, R.; Xu, K.; Zhou, T.; Acharya, P.; Lemmin, T.; Liu, K.; Ozorowski, G.; Soto, C.; Taft, J.D.; Bailer, R.T.; et al. Fusion peptide of HIV-1 as a site of vulnerability to neutralizing antibody. Science 2016, 352, 828-833. [CrossRef]

316. Schommers, P.; Gruell, H.; Abernathy, M.E.; Tran, M.K.; Dingens, A.S.; Gristick, H.B.; Barnes, C.O.; Schoofs, T.; Schlotz, M.; Vanshylla, K.; et al. Restriction of HIV-1 Escape by a Highly Broad and Potent Neutralizing Antibody. Cell 2020, 180, 471-489.e22. [CrossRef]

317. Gaube, G.; Armero, A.; Salmona, M.; Nere, M.L.; Mahjoub, N.; Lascoux-Combe, C.; Gabassi, A.; Gallien, S.; Amara, A.; Molina, J.M.; et al. Characterization of HIV-1 diversity in various compartments at the time of primary infection by ultradeep sequencing. Sci Rep. 2020, 10, 2409. [CrossRef] [PubMed]

318. Miller, R.L.; Ponte, R.; Jones, B.R.; Kinloch, N.N.; Omondi, F.H.; Jenabian, M.A.; Dupuy, F.P.; Fromentin, R.; Brassard, P.; Mehraj, V.; et al. HIV Diversity and Genetic Compartmentalization in Blood and Testes during Suppressive Antiretroviral Therapy. J. Virol. 2019, 93. [CrossRef]

319. Armero, A.; Berthet, N.; Avarre, J.C. Intra-Host Diversity of SARS-Cov-2 Should Not Be Neglected: Case of the State of Victoria, Australia. Viruses 2021, 13, 133. [CrossRef]

320. Shen, Z.; Xiao, Y.; Kang, L.; Ma, W.; Shi, L.; Zhang, L.; Zhou, Z.; Yang, J.; Zhong, J.; Yang, D.; et al. Genomic diversity of SARS-CoV-2 in Coronavirus Disease 2019 patients. Clin. Infect. Dis. 2020. [CrossRef]

321. Jary, A.; Leducq, V.; Malet, I.; Marot, S.; Klement-Frutos, E.; Teyssou, E.; Soulie, C.; Abdi, B.; Wirden, M.; Pourcher, V.; et al. Evolution of viral quasispecies during SARS-CoV-2 infection. Clin. Microbiol. Infect. 2020, 26, 1560.e1-1560.e4. [CrossRef]

322. Karamitros, T.; Papadopoulou, G.; Bousali, M.; Mexias, A.; Tsiodras, S.; Mentis, A. SARS-CoV-2 exhibits intra-host genomic plasticity and low-frequency polymorphic quasispecies. J. Clin. Virol. 2020, 131, 104585. [CrossRef]

323. Rueca, M.; Bartolini, B.; Gruber, C.E.M.; Piralla, A.; Baldanti, F.; Giombini, E.; Messina, F.; Marchioni, L.; Ippolito, G.; Di Caro, A.; et al. Compartmentalized Replication of SARS-Cov-2 in Upper vs. Lower Respiratory Tract Assessed by Whole Genome Quasispecies Analysis. Microorganisms 2020, 8, 1302. [CrossRef]

324. Lythgoe, K.A.; Hall, M.; Ferretti, L.; de Cesare, M.; MacIntyre-Cockett, G.; Trebes, A.; Andersson, M.; Otecko, N.; Wise, E.L.; Moore, N.; et al. SARS-CoV-2 within-host diversity and transmission. Science 2021. [CrossRef]

325. Wang, Y.; Wang, D.; Zhang, L.; Sun, W.; Zhang, Z.; Chen, W.; Zhu, A.; Huang, Y.; Xiao, F.; Yao, J.; et al. Intra-host variation and evolutionary dynamics of SARS-CoV-2 populations in COVID-19 patients. Genome Med. 2021, 13, 30. [CrossRef]

326. Voloch, C.M.; da Silva, F.R.; de Almeida, L.G.P.; Brustolini, O.J.; Cardoso, C.C.; Gerber, A.L.; Guimarães, A.P.D.C.; Leitão, I.D.C.; Mariani, D. Intra-host evolution during SARS-CoV-2 persistent infection. medRxiv 2020. [CrossRef]

327. Hensley, M.K.; Bain, W.G.; Jacobs, J.; Nambulli, S.; Parikh, U.; Cillo, A.; Staines, B.; Heaps, A.; Sobolewski, M.D.; Rennick, L.J.; et al. Intractable Coronavirus Disease 2019 (COVID-19) and Prolonged Severe Acute Respiratory Syndrome Coronavirus 2 (SARS-CoV-2) Replication in a Chimeric Antigen Receptor-Modified T-Cell Therapy Recipient: A Case Study. Clin. Infect. Dis. 2021. [CrossRef]

328. Braun, K.M.; Moreno, G.K.; Halfmann, P.J.; Hodcroft, E.B.; Baker, D.A.; Boehm, E.C.; Weiler, A.M.; Haj, A.K.; Hatta, M.; Chiba, S.; et al. Transmission of SARS-CoV-2 in domestic cats imposes a narrow bottleneck. PLoS Pathog. 2021, 17, e1009373. [CrossRef]

329. Korber, B.; Fischer, W.M.; Gnanakaran, S.; Yoon, H.; Theiler, J.; Abfalterer, W.; Hengartner, N.; Giorgi, E.E.; Bhattacharya, T.; Foley, B.; et al. Tracking Changes in SARS-CoV-2 Spike: Evidence that D614G Increases Infectivity of the COVID-19 Virus. Cell 2020, 182, 812-827.e19. [CrossRef] 
330. Yurkovetskiy, L.; Wang, X.; Pascal, K.E.; Tomkins-Tinch, C.; Nyalile, T.P.; Wang, Y.; Baum, A.; Diehl, W.E.; Dauphin, A.; Carbone, C.; et al. Structural and Functional Analysis of the D614G SARS-CoV-2 Spike Protein Variant. Cell 2020, 183, 739-751.e8. [CrossRef]

331. Mansbach, R.A.; Chakraborty, S.; Nguyen, K.; Montefiori, D.; Korber, B.; Gnanakaran, S. The SARS-CoV-2 Spike Variant D614G Favors an Open Conformational State. bioRxiv 2020. [CrossRef]

332. Zhang, L.; Jackson, C.B.; Mou, H.; Ojha, A.; Rangarajan, E.S.; Izard, T.; Farzan, M.; Choe, H. The D614G mutation in the SARS-CoV-2 spike protein reduces $\mathrm{S} 1$ shedding and increases infectivity. bioRxiv 2020. [CrossRef]

333. Hou, Y.J.; Chiba, S.; Halfmann, P.; Ehre, C.; Kuroda, M.; Dinnon, K.H., 3rd; Leist, S.R.; Schafer, A.; Nakajima, N.; Takahashi, K.; et al. SARS-CoV-2 D614G variant exhibits efficient replication ex vivo and transmission in vivo. Science 2020, 370, 1464-1468. [CrossRef]

334. Plante, J.A.; Liu, Y.; Liu, J.; Xia, H.; Johnson, B.A.; Lokugamage, K.G.; Zhang, X.; Muruato, A.E.; Zou, J.; Fontes-Garfias, C.R.; et al. Spike mutation D614G alters SARS-CoV-2 fitness. Nature 2020. [CrossRef]

335. Shi, P.Y.; Plante, J.; Liu, Y.; Liu, J.; Xia, H.; Johnson, B.; Lokugamage, K.; Zhang, X.; Muruato, A.; Zou, J.; et al. Spike mutation D614G alters SARS-CoV-2 fitness and neutralization susceptibility. Res. Sq. 2020. [CrossRef]

336. Zhou, B.; Thi Nhu Thao, T.; Hoffmann, D.; Taddeo, A.; Ebert, N.; Labroussaa, F.; Pohlmann, A.; King, J ; Steiner, S.; Kelly, J.N.; et al. SARS-CoV-2 spike D614G change enhances replication and transmission. Nature 2021. [CrossRef]

337. Kamps, B.S. Covid Reference/Variants. Available online: https:/ / covidreference.com/variants (accessed on 25 March 2021).

338. Wang, Z.; Schmidt, F.; Weisblum, Y.; Muecksch, F.; Barnes, C.O.; Finkin, S.; Schaefer-Babajew, D.; Cipolla, M.; Gaebler, C.; Lieberman, J.A.; et al. mRNA vaccine-elicited antibodies to SARS-CoV-2 and circulating variants. Nature 2021. [CrossRef]

339. Tada, T.; Dcosta, B.M.; Samanovic-Golden, M.; Herati, R.S.; Cornelius, A.; Mulligan, M.J.; Landau, N.R. Neutralization of viruses with European, South African, and United States SARS-CoV-2 variant spike proteins by convalescent sera and BNT162b2 mRNA vaccine-elicited antibodies. bioRxiv 2021. [CrossRef]

340. Hoffmann, M.; Arora, P.; Groß, R.; Seidel, A.; Hörnich, B.; Hahn, A.; Krüger, N.; Graichen, L.; Hofmann-Winkler, H.; Kempf, A.; et al. SARS-CoV-2 variants B.1.351 and B.1.1.248: Escape from therapeutic antibodies and antibodies induced by infection and vaccination. bioRxiv 2021. [CrossRef]

341. Wu, K.; Werner, A.P.; Koch, M.; Choi, A.; Narayanan, E.; Stewart-Jones, G.B.E.; Colpitts, T.; Bennett, H.; Boyoglu-Barnum, S.; Shi, W.; et al. Serum Neutralizing Activity Elicited by mRNA-1273 Vaccine-Preliminary Report. N. Engl. J. Med. 2021. [CrossRef]

342. Liu, Y.; Liu, J.; Xia, H.; Zhang, X.; Fontes-Garfias, C.R.; Swanson, K.A.; Cai, H.; Sarkar, R.; Chen, W.; Cutler, M.; et al. Neutralizing Activity of BNT162b2-Elicited Serum-Preliminary Report. N. Engl. J. Med. 2021. [CrossRef] [PubMed]

343. Garcia-Beltran, W.F.; Lam, E.C.S.; Denis, K.; Nitido, A.D.; Garcia, Z.H.; Hauser, B.M.; Feldman, J.; Pavlovic, M.N.; Gregory, D.J.; Poznansky, M.C.; et al. Multiple SARS-CoV-2 variants escape neutralization by vaccine-induced humoral immunity. Cell 2021. [CrossRef]

344. Sahin, U.; Muik, A.; Vogler, I.; Derhovanessian, E.; Kranz, L.M.; Vormehr, M.; Quandt, J.; Bidmon, N.; Ulges, A.; Baum, A.; et al. BNT162b2 induces SARS-CoV-2-neutralising antibodies and T cells in humans. medRxiv 2020. [CrossRef]

345. Skelly, D.T.; Harding, A.C.; Gilbert-Jaramillo, J.; Knight, M.L.; Longet, S.; Brown, A.; Adele, S.; Adland, E.; Brown, H.; Team, M.L.; et al. Vaccine-induced immunity provides more robust heterotypic immunity than natural infection to emerging SARS-CoV-2 variants of concern. Res. Sq. 2021. [CrossRef]

346. Zost, S.J.; Gilchuk, P.; Chen, R.E.; Case, J.B.; Reidy, J.X.; Trivette, A.; Nargi, R.S.; Sutton, R.E.; Suryadevara, N.; Chen, E.C.; et al. Rapid isolation and profiling of a diverse panel of human monoclonal antibodies targeting the SARS-CoV-2 spike protein. Nat. Med. 2020, 26, 1422-1427. [CrossRef]

347. McCallum, M.; De Marco, A.; Lempp, F.A.; Tortorici, M.A.; Pinto, D.; Walls, A.C.; Beltramello, M.; Chen, A.; Liu, Z.; Zatta, F.; et al. N-terminal domain antigenic mapping reveals a site of vulnerability for SARS-CoV-2. Cell 2021. [CrossRef]

348. Chand, M.; Hopkins, S.; Dabrera, G.; Achison, C.; Barclay, W.; Ferguson, N.; Volz, E.; Loman, N.; Rambaut, A.; Barrett, J. Investigation of novel SARS-COV-2 variant: Variant of Concern 202012/01. Available online: https://assets.publishing. service.gov.uk/government/uploads/system/uploads/attachment_data/file/959426/Variant_of_Concern_VOC_202012_01_ Technical_Briefing_5.pdf (accessed on 15 March 2021).

349. Tegally, H.; Wilkinson, E.; Giovanetti, M.; Iranzadeh, A.; Fonseca, V.; Giandhari, J.; Doolabh, D.; Pillay, S.; San, E.J.; Msomi, N.; et al. Emergence of a SARS-CoV-2 variant of concern with mutations in spike glycoprotein. Nature 2021. [CrossRef]

350. Faria, N.R.; Mellan, T.A.; Whittaker, C.; Claro, I.M.; Candido, D.D.S.; Mishra, S.; Crispim, M.A.E.; Sales, F.C.S.; Hawryluk, I.; McCrone, J.T.; et al. Genomics and epidemiology of the P.1 SARS-CoV-2 lineage in Manaus, Brazil. Science 2021, 372, 815-821. [CrossRef]

351. Cherian, S.; Potdar, V.; Jadhav, S.; Yadav, P.; Gupta, N.; Das, M.; Rakshit, P.; Singh, S.; Abraham, P.; Panda, S. Convergent evolution of SARS-CoV-2 spike mutations, L452R, E484Q and P681R, in the second wave of COVID-19 in Maharashtra, India. bioRxiv 2021. [CrossRef]

352. Yadav, P.D.; Sapkal, G.N.; Abraham, P.; Ella, R.; Deshpande, G.; Patil, D.Y.; Nyayanit, D.A.; Gupta, N.; Sahay, R.R.; Shete, A.M.; et al. Neutralization of variant under investigation B.1.617 with sera of BBV152 vaccinees. bioRxiv 2021. [CrossRef]

353. Kidd, M.; Richter, A.; Best, A.; Cumley, N.; Mirza, J.; Percival, B.; Mayhew, M.; Megram, O.; Ashford, F.; White, T.; et al. S-variant SARS-CoV-2 lineage B1.1.7 is associated with significantly higher viral loads in samples tested by ThermoFisher TaqPath RT-qPCR. J. Infect. Dis. 2021. [CrossRef] 
354. Frampton, D.; Rampling, T.; Cross, A.; Bailey, H.; Heaney, J.; Byott, M.; Scott, R.; Sconza, R.; Price, J.; Margaritis, M.; et al. Genomic characteristics and clinical effect of the emergent SARS-CoV-2 B.1.1.7 lineage in London, UK: A whole-genome sequencing and hospital-based cohort study. Lancet Infect. Dis. 2021. [CrossRef]

355. Davies, N.G.; Abbott, S.; Barnard, R.C.; Jarvis, C.I.; Kucharski, A.J.; Munday, J.D.; Pearson, C.A.B.; Russell, T.W.; Tully, D.C.; Washburne, A.D.; et al. Estimated transmissibility and impact of SARS-CoV-2 lineage B.1.1.7 in England. Science 2021. [CrossRef]

356. Volz, E.; Mishra, S.; Chand, M.; Barrett, J.C.; Johnson, R.; Geidelberg, L.; Hinsley, W.R.; Laydon, D.J.; Dabrera, G.; O’Toole, A.; et al. Assessing transmissibility of SARS-CoV-2 lineage B.1.1.7 in England. Nature 2021. [CrossRef] [PubMed]

357. Washington, N.L.; Gangavarapu, K.; Zeller, M.; Bolze, A.; Cirulli, E.T.; Schiabor Barrett, K.M.; Larsen, B.B.; Anderson, C.; White, S.; Cassens, T.; et al. Emergence and rapid transmission of SARS-CoV-2 B.1.1.7 in the United States. Cell 2021, 184, 2587-2594.e7. [CrossRef]

358. Kissler, S.; Fauver, J.R.; Mack, C.; Tai, C.G.; Breban, M.I.; Watkins, A.E.; Samant, R.M.; Anderson, D.J.; Ho, D.D.; Grubaugh, N.D.; et al. Densely sampled viral trajectories suggest longer duration of acute infection with B.1.1.7 variant relative to non-B.1.1.7 SARS-CoV-2. medRxiv 2021. [CrossRef]

359. Ratcliff, J.; Nguyen, D.; Fish, M.; Rynne, J.; Jennings, A.; Williams, S.; Al-Beidh, F.; Bonsall, D.; Evans, A.; Golubchik, T.; et al. Virological and serological characterization of critically ill patients with COVID-19 in the UK: Interactions of viral load, antibody status and B.1.1.7 variant infection. J. Infect. Dis. 2021. [CrossRef]

360. Davies, N.G.; Jarvis, C.I.; Edmunds, W.J.; Jewell, N.P.; Diaz-Ordaz, K.; Keogh, R.H. Increased hazard of death in community-tested cases of SARS-CoV-2 Variant of Concern 202012/01. medRxiv 2021. [CrossRef]

361. Iacobucci, G. Covid-19: New UK variant may be linked to increased death rate, early data indicate. BMJ 2021, 372, n230. [CrossRef] [PubMed]

362. Challen, R.; Brooks-Pollock, E.; Read, J.M.; Dyson, L.; Tsaneva-Atanasova, K.; Danon, L. Risk of mortality in patients infected with SARS-CoV-2 variant of concern 202012/1: Matched cohort study. BMJ 2021, 372, n579. [CrossRef]

363. Grint, D.J.; Wing, K.; Williamson, E.; McDonald, H.I.; Bhaskaran, K.; Evans, D.; Evans, S.J.; Walker, A.J.; Hickman, G.; Nightingale, E.; et al. Case fatality risk of the SARS-CoV-2 variant of concern B.1.1.7 in England, 16 November to 5 February. Eurosurveillance 2021, 26, 2100256. [CrossRef] [PubMed]

364. Collier, D.A.; De Marco, A.; Ferreira, I.A.T.M.; Meng, B.; Datir, R.; Walls, A.C.; Kemp, S.S.A.; Bassi, J.; Pinto, D. Sensitivity of SARS-CoV-2 B.1.1.7 to mRNA vaccine-elicited antibodies. Nature 2021. [CrossRef] [PubMed]

365. Shen, X.; Tang, H.; McDanal, C.; Wagh, K.; Fischer, W.; Theiler, J.; Yoon, H.; Li, D.; Haynes, B.F.; Sanders, K.O.; et al. SARS-CoV-2 variant B.1.1.7 is susceptible to neutralizing antibodies elicited by ancestral spike vaccines. Cell Host Microbe 2021. [CrossRef]

366. Emary, K.R.W.; Golubchik, T.; Aley, P.K.; Ariani, C.V.; Angus, B.; Bibi, S.; Blane, B.; Bonsall, D.; Cicconi, P.; Charlton, S.; et al. Efficacy of ChAdOx1 nCoV-19 (AZD1222) vaccine against SARS-CoV-2 variant of concern 202012/01 (B.1.1.7): An exploratory analysis of a randomised controlled trial. Lancet 2021. [CrossRef]

367. Munitz, A.; Yechezkel, M.; Dickstein, Y.; Yamin, D.; Gerlic, M. BNT162b2 vaccination effectively prevents the rapid rise of SARS-CoV-2 variant B.1.1.7 in high-risk populations in Israel. Cell Rep. Med. 2021, 2, 100264. [CrossRef]

368. Graham, C.; Seow, J.; Huettner, I.; Khan, H.; Kouphou, N.; Acors, S.; Winstone, H.; Pickering, S.; Galao, R.P.; Dupont, L.; et al. Neutralization potency of monoclonal antibodies recognizing dominant and subdominant epitopes on SARS-CoV-2 Spike is impacted by the B.1.1.7 variant. Immunity 2021. [CrossRef]

369. Mandavilli, A. In Oregon, Scientists Find a Virus Variant With a Worrying Mutation-In a single sample, geneticists discovered a version of the coronavirus first identified in Britain with a mutation originally reported in South Africa. New York Times. 5 March 2021. Available online: https://www.nytimes.com/2021/03/05/health/virus-oregon-variant.html (accessed on 26 March 2021).

370. Chen, R.E.; Zhang, X.; Case, J.B.; Winkler, E.S.; Liu, Y.; VanBlargan, L.A.; Liu, J.; Errico, J.M.; Xie, X.; Suryadevara, N.; et al. Resistance of SARS-CoV-2 variants to neutralization by monoclonal and serum-derived polyclonal antibodies. Nat. Med. 2021, 27, 717-726. [CrossRef]

371. Starr, T.N.; Greaney, A.J.; Hilton, S.K.; Ellis, D.; Crawford, K.H.D.; Dingens, A.S.; Navarro, M.J.; Bowen, J.E.; Tortorici, M.A.; Walls, A.C.; et al. Deep Mutational Scanning of SARS-CoV-2 Receptor Binding Domain Reveals Constraints on Folding and ACE2 Binding. Cell 2020, 182, 1295-1310.e20. [CrossRef]

372. Gu, H.; Chen, Q.; Yang, G.; He, L.; Fan, H.; Deng, Y.-Q.; Wang, Y.; Teng, Y.; Zhao, Z.; Cui, Y.; et al. Adaptation of SARS-CoV-2 in BALB/c mice for testing vaccine efficacy. Science 2020, 369, 1603-1607. [CrossRef] [PubMed]

373. Nelson, G.; Buzko, O.; Spilman, P.; Niazi, K.; Rabizadeh, S.; Soon-Shiong, P. Molecular dynamic simulation reveals E484K mutation enhances spike RBD-ACE2 affinity and the combination of E484K, K417N and N501Y mutations (501Y.V2 variant) induces conformational change greater than N501Y mutant alone, potentially resulting in an escape mutant. bioRxiv 2021. [CrossRef]

374. Greaney, A.J.; Starr, T.N.; Gilchuk, P.; Zost, S.J.; Binshtein, E.; Loes, A.N.; Hilton, S.K.; Huddleston, J.; Eguia, R.; Crawford, K.H.D.; et al. Complete Mapping of Mutations to the SARS-CoV-2 Spike Receptor-Binding Domain that Escape Antibody Recognition. Cell Host Microbe 2021, 29, 44-57.e9. [CrossRef] [PubMed]

375. Wang, P.; Liu, L.; Iketani, S.; Luo, Y.; Guo, Y.; Wang, M.; Yu, J.; Zhang, B.; Kwong, P.D.; Graham, B.S.; et al. Increased Resistance of SARS-CoV-2 Variants, B.1.351 and B.1.1.7 to Antibody Neutralization. bioRxiv 2021. [CrossRef]

376. Li, Q.; Nie, J.; Wu, J.; Zhang, L.; Ding, R.; Wang, H.; Zhang, Y.; Li, T.; Liu, S.; Zhang, M.; et al. SARS-CoV-2 501Y.V2 variants lack higher infectivity but do have immune escape. Cell 2021. [CrossRef] 
377. Weisblum, Y.; Schmidt, F.; Zhang, F.; DaSilva, J.; Poston, D.; Lorenzi, J.C.C.; Muecksch, F.; Rutkowska, M.; Hoffmann, H.-H.; Michailidis, E.; et al. Escape from neutralizing antibodies by SARS-CoV-2 spike protein variants. eLife 2020, 9, e61312. [CrossRef]

378. Wibmer, C.K.; Ayres, F.; Hermanus, T.; Madzivhandila, M.; Kgagudi, P.; Oosthuysen, B.; Lambson, B.E.; de Oliveira, T.; Vermeulen, M.; van der Berg, K.; et al. SARS-CoV-2 501Y.V2 escapes neutralization by South African COVID-19 donor plasma. Nat. Med. 2021. [CrossRef] [PubMed]

379. Hoffmann, M.; Arora, P.; Groß, R.; Seidel, A.; Hörnich, B.F.; Hahn, A.S.; Krüger, N.; Graichen, L.; Hofmann-Winkler, H.; Kempf, A.; et al. SARS-CoV-2 variants B.1.351 and P.1 escape from neutralizing antibodies. Cell 2021. [CrossRef]

380. Dejnirattisai, W.; Zhou, D.; Supasa, P.; Liu, C.; Mentzer, A.J.; Ginn, H.M.; Zhao, Y.; Duyvesteyn, H.M.E.; Tuekprakhon, A.; Nutalai, R.; et al. Antibody evasion by the P.1 strain of SARS-CoV-2. Cell 2021. [CrossRef] [PubMed]

381. Wang, G.L.; Wang, Z.Y.; Duan, L.J.; Meng, Q.C.; Jiang, M.D.; Cao, J.; Yao, L.; Zhu, K.L.; Cao, W.C.; Ma, M.J. Susceptibility of Circulating SARS-CoV-2 Variants to Neutralization. N. Engl. J. Med. 2021. [CrossRef]

382. Zhou, D.; Dejnirattisai, W.; Supasa, P.; Liu, C.; Mentzer, A.J.; Ginn, H.M.; Zhao, Y.; Duyvesteyn, H.M.E.; Tuekprakhon, A.; Nutalai, R.; et al. Evidence of escape of SARS-CoV-2 variant B.1.351 from natural and vaccine-induced sera. Cell 2021. [CrossRef]

383. Wang, P.; Nair, M.S.; Liu, L.; Iketani, S.; Luo, Y.; Guo, Y.; Wang, M.; Yu, J.; Zhang, B.; Kwong, P.D.; et al. Antibody Resistance of SARS-CoV-2 Variants, B.1.351 and B.1.1.7. Nature 2021. [CrossRef] [PubMed]

384. Edara, V.V.; Norwood, C.; Floyd, K.; Lai, L.; Davis-Gardner, M.E.; Hudson, W.H.; Mantus, G.; Nyhoff, L.E.; Adelman, M.W.; Fineman, R.; et al. Infection and vaccine-induced antibody binding and neutralization of the B.1.351 SARS-CoV-2 variant. Cell Host Microbe 2021. [CrossRef]

385. Planas, D.; Bruel, T.; Grzelak, L.; Guivel-Benhassine, F.; Staropoli, I.; Porrot, F.; Planchais, C.; Buchrieser, J.; Rajah, M.M.; Bishop, E.; et al. Sensitivity of infectious SARS-CoV-2 B.1.1.7 and B.1.351 variants to neutralizing antibodies. Nat. Med. 2021, 27, 917-924. [CrossRef] [PubMed]

386. Xie, X.; Liu, Y.; Liu, J.; Zhang, X.; Zou, J.; Fontes-Garfias, C.R.; Xia, H.; Swanson, K.A.; Cutler, M.; Cooper, D.; et al. Neutralization of SARS-CoV-2 spike 69/70 deletion, E484K and N501Y variants by BNT162b2 vaccine-elicited sera. Nat. Med. 2021. [CrossRef] [PubMed]

387. Greaney, A.J.; Starr, T.N.; Barnes, C.O.; Weisblum, Y.; Schmidt, F.; Caskey, M.; Gaebler, C.; Cho, A.; Agudelo, M.; Finkin, S.; et al. Mutational escape from the polyclonal antibody response to SARS-CoV-2 infection is largely shaped by a single class of antibodies. bioRxiv 2021. [CrossRef]

388. Barnes, C.O.; Jette, C.A.; Abernathy, M.E.; Dam, K.-M.A.; Esswein, S.R.; Gristick, H.B.; Malyutin, A.G.; Sharaf, N.G.; HueyTubman, K.E.; Lee, Y.E.; et al. SARS-CoV-2 neutralizing antibody structures inform therapeutic strategies. Nature 2020, 588, 682-687. [CrossRef] [PubMed]

389. Yuan, M.; Huang, D.; Lee, C.D.; Wu, N.C.; Jackson, A.M.; Zhu, X.; Liu, H.; Peng, L.; van Gils, M.J.; Sanders, R.W.; et al. Structural and functional ramifications of antigenic drift in recent SARS-CoV-2 variants. Science 2021. [CrossRef]

390. Singh, J.; Rahman, S.A.; Ehtesham, N.Z.; Hira, S.; Hasnain, S.E. SARS-CoV-2 variants of concern are emerging in India. Nat. Med. 2021. [CrossRef]

391. Bernal, J.L.; Andrews, N.; Gower, C.; Gallagher, E.; Simmons, R.; Thelwall, S.; Stowe, J.; Tessier, E.; Groves, N.; Dabrera, G.; et al. Effectiveness of COVID-19 vaccines against the B.1.617.2 variant. medRxiv 2021. [CrossRef]

392. Tada, T.; Zhou, H.; Dcosta, B.M.; Samanovic, M.I.; Mulligan, M.J.; Landau, N.R. The Spike Proteins of SARS-CoV-2 B.1.617 and B.1.618 Variants Identified in India Provide Partial Resistance to Vaccine-elicited and Therapeutic Monoclonal Antibodies. bioRxiv 2021. [CrossRef]

393. Public Health England. Confirmed Cases of COVID-19 Variants Identified in UK. Latest Updates on SARS-CoV-2 Variants Detected in UK. Available online: https://www.gov.uk/government/news/confirmed-cases-of-covid-19-variants-identified-inuk (accessed on 30 May 2021).

394. Edara, V.V.; Lai, L.; Sahoo, M.K.; Floyd, K.; Sibai, M.; Solis, D.; Flowers, M.W.; Hussaini, L.; Ciric, C.R.; Bechnack, S.; et al. Infection and vaccine-induced neutralizing antibody responses to the SARS-CoV-2 B.1.617.1 variant. bioRxiv 2021. [CrossRef]

395. Motozono, C.; Toyoda, M.; Zahradnik, J.; Saito, A.; Nasser, H.; Tan, T.S.; Ngare, I.; Kimura, I.; Uriu, K.; Kosugi, Y.; et al SARS-CoV-2 spike L452R variant evades cellular immunity and increases infectivity. Cell Host Microbe 2021. [CrossRef] [PubMed]

396. Campbell, F.; Archer, B.; Laurenson-Schafer, H.; Jinnai, Y.; Konings, F.; Batra, N.; Pavlin, B.; Vandemaele, K.; Van Kerkhove, M.D.; Jombart, T.; et al. Increased transmissibility and global spread of SARS-CoV-2 variants of concern as at June 2021. Eurosurveillance 2021, 26, 2100509. [CrossRef]

397. Wang, R.; Zhang, Q.; Ge, J.; Ren, W.; Zhang, R.; Lan, J.; Ju, B.; Su, B.; Yu, F.; Chen, P.; et al. Analysis of SARS-CoV-2 variant mutations reveals neutralization escape mechanisms and the ability to use ACE2 receptors from additional species. Immunity 2021. [CrossRef] [PubMed]

398. Montagutelli, X.; Prot, M.; Levillayer, L.; Salazar, E.B.; Jouvion, G.; Conquet, L.; Donati, F.; Albert, M.; Gambaro, F.; Behillil, S.; et al. The B1.351 and P.1 variants extend SARS-CoV-2 host range to mice. bioRxiv 2021. [CrossRef]

399. Da Silva Francisco, R.; Benites, L.F.; Lamarca, A.P.; de Almeida, L.G.P.; Hansen, A.W.; Gularte, J.S.; Demoliner, M.; Gerber, A.L.; de Guimarães, A.C.P.; Antunes, A.K.E.; et al. Pervasive transmission of E484K and emergence of VUI-NP13L with evidence of SARS-CoV-2 co-infection events by two different lineages in Rio Grande do Sul, Brazil. medRxiv 2021. [CrossRef] 
400. Bailly, B.; Guilpain, L.; Bouiller, K.; Chirouze, C.; N’Debi, M.; Soulier, A.; Demontant, V.; Pawlotsky, J.-M.; Rodriguez, C.; Fourati, S. BNT162b2 mRNA vaccination did not prevent an outbreak of SARS COV-2 variant 501Y.V2 in an elderly nursing home but reduced transmission and disease severity. Clin. Infect. Dis. 2021. [CrossRef] [PubMed]

401. Abu-Raddad, L.J.; Chemaitelly, H.; Butt, A.A. National Study Group for COVID-19 Vaccination. Effectiveness of the BNT162b2 Covid-19 Vaccine against the B.1.1.7 and B.1.351 Variants. N. Engl. J. Med. 2021. [CrossRef]

402. Sadoff, J.; Gray, G.; Vandebosch, A.; Cardenas, V.; Shukarev, G.; Grinsztejn, B.; Goepfert, P.A.; Truyers, C.; Fennema, H.; Spiessens, B.; et al. Safety and Efficacy of Single-Dose Ad26.COV2.S Vaccine against Covid-19. N. Engl. J. Med. 2021. [CrossRef] [PubMed]

403. Madhi, S.A.; Baillie, V.; Cutland, C.L.; Voysey, M.; Koen, A.L.; Fairlie, L.; Padayachee, S.D.; Dheda, K.; Barnabas, S.L.; Bhorat, Q.E.; et al. Efficacy of the ChAdOx1 nCoV-19 Covid-19 Vaccine against the B.1.351 Variant. N. Engl. J. Med. 2021. [CrossRef] [PubMed]

404. Cele, S.; Gazy, I.; Jackson, L.; Hwa, S.H.; Tegally, H.; Lustig, G.; Giandhari, J.; Pillay, S.; Wilkinson, E.; Naidoo, Y.; et al. Escape of SARS-CoV-2 501Y.V2 from neutralization by convalescent plasma. Nature 2021. [CrossRef]

405. Moyo-Gwete, T.; Madzivhandila, M.; Makhado, Z.; Ayres, F.; Mhlanga, D.; Oosthuysen, B.; Lambson, B.E.; Kgagudi, P.; Tegally, H.; Iranzadeh, A.; et al. Cross-Reactive Neutralizing Antibody Responses Elicited by SARS-CoV-2 501Y.V2 (B.1.351). N. Engl. J. Med. 2021, 384, 2161-2163. [CrossRef]

406. Wu, K.; Choi, A.; Koch, M.; Ma, L.; Hill, A.; Nunna, N.; Huang, W.; Oestreicher, J.; Colpitts, T.; Bennett, H.; et al. Preliminary Analysis of Safety and Immunogenicity of a SARS-CoV-2 Variant Vaccine Booster. medRxiv 2021. [CrossRef]

407. Pangolin Contributors. PANGO Lineages. Available online: http:/ / www.Cov-lineages.org (accessed on 31 May 2021).

408. Nextstrain Team. Genomic Epidemiology of Novel Coronavirus-Global Subsampling. Available online: https://nextstrain.org/ ncov/global (accessed on 31 May 2021).

409. WHO. SARS-CoV-2 Variants of Concern and Variants of Interest, Updated 31 May 2021. Available online: https://www.who.int/ en/activities / tracking-SARS-CoV-2-variants / (accessed on 31 May 2021).

410. Tegally, H.; Wilkinson, E.; Lessells, R.J.; Giandhari, J.; Pillay, S.; Msomi, N.; Mlisana, K.; Bhiman, J.N.; von Gottberg, A.; Walaza, S.; et al. Sixteen novel lineages of SARS-CoV-2 in South Africa. Nat. Med. 2021. [CrossRef]

411. Happi, C.; Ihekweazu, C.; Nkengasong, J.; Oluniyi, P.E.; Olawoye, I. Detection of SARS-CoV-2 P681H Spike Protein Variant in Nigeria. Detection of SARS-CoV-2 P681H Spike Protein Variant in Nigeria. Virological 2020. Available online: https:/ /virological. $\mathrm{org} / \mathrm{t} /$ detection-of-sars-cov-2-p681h-spike-protein-variant-in-nigeria/567 (accessed on 20 March 2021).

412. Oude Munnink, B.B.; Sikkema, R.S.; Nieuwenhuijse, D.F.; Molenaar, R.J.; Munger, E.; Molenkamp, R.; van der Spek, A.; Tolsma, P.; Rietveld, A.; Brouwer, M.; et al. Transmission of SARS-CoV-2 on mink farms between humans and mink and back to humans. Science 2021, 371, 172-177. [CrossRef] [PubMed]

413. Meng, B.; Kemp, S.A.; Papa, G.; Datir, R.; Ferreira, I.A.T.M.; Marelli, S.; Harvey, W.T.; Lytras, S.; Mohamed, A.; Gallo, G.; et al. Recurrent emergence of SARS-CoV-2 spike deletion H69/V70 and its role in the variant of concern lineage B.1.1.7. Cell Rep. 2021. [CrossRef]

414. McCarthy, K.R.; Rennick, L.J.; Nambulli, S.; Robinson-McCarthy, L.R.; Bain, W.G.; Haidar, G.; Duprex, W.P. Recurrent deletions in the SARS-CoV-2 spike glycoprotein drive antibody escape. Science 2021. [CrossRef]

415. Tada, T.; Dcosta, B.M.; Zhou, H.; Vaill, A.; Kazmierski, W.; Landau, N.R. Decreased neutralization of SARS-CoV-2 global variants by therapeutic anti-spike protein monoclonal antibodies. bioRxiv 2021. [CrossRef]

416. Hoffmann, M.; Zhang, L.; Kruger, N.; Graichen, L.; Kleine-Weber, H.; Hofmann-Winkler, H.; Kempf, A.; Nessler, S.; Riggert, J.; Winkler, M.S.; et al. SARS-CoV-2 mutations acquired in mink reduce antibody-mediated neutralization. Cell Rep. 2021, $35,109017$. [CrossRef]

417. Hodcroft, E.B.; Zuber, M.; Nadeau, S.; Crawford, K.H.D.; Bloom, J.D.; Veesler, D.; Vaughan, T.G.; Comas, I.; Candelas, F.G.; Stadler, T.; et al. Emergence and spread of a SARS-CoV-2 variant through Europe in the summer of 2020. medRxiv 2020. [CrossRef]

418. Zhang, W.; Davis, B.D.; Chen, S.S.; Sincuir Martinez, J.M.; Plummer, J.T.; Vail, E. Emergence of a Novel SARS-CoV-2 Variant in Southern California. JAMA 2021. [CrossRef]

419. Deng, X.; Garcia-Knight, M.A.; Khalid, M.M.; Servellita, V.; Wang, C.; Morris, M.K.; Sotomayor-Gonzalez, A.; Glasner, D.R.; Reyes, K.R.; Gliwa, A.S.; et al. Transmission, infectivity, and neutralization of a spike L452R SARS-CoV-2 variant. Cell 2021. [CrossRef]

420. Shen, X.; Tang, H.; Pajon, R.; Smith, G.; Glenn, G.M.; Shi, W.; Korber, B.; Montefiori, D.C. Neutralization of SARS-CoV-2 Variants, B.1.429 and B.1.351. N. Engl. J. Med. 2021. [CrossRef] [PubMed]

421. Tu, H.; Avenarius, M.R.; Kubatko, L.; Hunt, M.; Pan, X.; Ru, P.; Garee, J.; Thomas, K.; Mohler, P.; Pancholi, P.; et al. Distinct Patterns of Emergence of SARS-CoV-2 Spike Variants including N501Y in Clinical Samples in Columbus Ohio. bioRxiv 2021. [CrossRef]

422. Hodcroft, E.B.; Domman, D.B.; Snyder, D.J.; Oguntuyo, K.; Van Diest, M.; Densmore, K.H.; Schwalm, K.C.; Femling, J.; Carroll, J.L.; Scott, R.S.; et al. Emergence in late 2020 of multiple lineages of SARS-CoV-2 Spike protein variants affecting amino acid position 677. medRxiv 2021. [CrossRef]

423. West, A.P.; Barnes, C.O.; Yang, Z.; Bjorkman, P.J. SARS-CoV-2 lineage B.1.526 emerging in the New York region detected by software utility created to query the spike mutational landscape. bioRxiv 2021. [CrossRef]

424. Annavajhala, M.K.; Mohri, H.; Zucker, J.E.; Sheng, Z.; Wang, P.; Gomez-Simmonds, A.; Ho, D.D.; Uhlemann, A.-C. A Novel SARS-CoV-2 Variant of Concern, B.1.526, Identified in New York. medRxiv 2021. [CrossRef]

425. Centers for Disease Control and Prevention. SARS-CoV-2 Variant Classifications and Definitions. Available online: https: / / www.cdc.gov/coronavirus/2019-ncov/variants/variant-info.html (accessed on 30 May 2021). 
426. Dudas, G.; Hong, S.L.; Potter, B.; Calvignac-Spencer, S.; Niatou-Singa, F.S.; Tombolomako, T.B.; Fuh-Neba, T.; Vickos, U.; Ulrich, M.; Leendertz, F.H.; et al. Travel-driven emergence and spread of SARS-CoV-2 lineage B.1.620 with multiple VOC-like mutations and deletions in Europe. medRxiv 2021. [CrossRef]

427. Bugembe, D.L.; Phan, M.V.T.; Ssewanyana, I.; Semanda, P.; Nansumba, H.; Dhaala, B.; Nabadda, S.; O’Toole, Á.N.; Rambaut, A.; Kaleebu, P.; et al. A SARS-CoV-2 lineage A variant (A.23.1) with altered spike has emerged and is dominating the current Uganda epidemic. medRxiv 2021. [CrossRef]

428. Tablizo, F.A.; Kim, K.M.; Lapid, C.M.; Castro, M.J.R.; Yangzon, M.S.L.; Maralit, B.A.; Ayes, M.E.C.; Cutiongco-de la Paz, E.M.; De Guzman, A.R.; Yap, J.M.C.; et al. Genome sequencing and analysis of an emergent SARS-CoV-2 variant characterized by multiple spike protein mutations detected from the Central Visayas Region of the Philippines. medRxiv 2021. [CrossRef]

429. Romero, P.E.; Dávila-Barclay, A.; Gonzáles, L.; Salvatierra, G.; Cuicapuza, D.; Solis, L.; Marcos, P.; Huancachoque, J.; Carhuaricra, D.; Rosadio, R.; et al. Novel sublineage within B.1.1.1 currently expanding in Peru and Chile, with a convergent deletion in the ORF1a gene ( $\Delta 3675-3677)$ and a novel deletion in the Spike gene $(\Delta 246-252, \mathrm{G75V}, \mathrm{T76I}, \mathrm{L} 452 \mathrm{Q}, \mathrm{F} 490 \mathrm{~S}, \mathrm{~T} 859 \mathrm{~N}$. Virological 2021. Available online: https:/ / virological.org/t/novel-sublineage-within-b-1-1-1-currently-expanding-in-peru-and-chile-with-aconvergent-deletion-in-the-orf1a-gene-3675-3677-and-a-novel-deletion-in-the-spike-gene-246-252-g75v-t76i-1452q-f490s-t859 $\mathrm{n} / 685$ (accessed on 3 June 2021).

430. Nguyen, P.; Neghaiwi, B. Vietnam detects hybrid of Indian and UK COVID-19 variants. Reuters. 29 May 2021. Available online: https://www.reuters.com/world/asia-pacific/vietnam-detects-hybrid-indian-uk-covid-19-variant-2021-05-29/ (accessed on 3 June 2021)

431. Plante, J.A.; Mitchell, B.M.; Plante, K.S.; Debbink, K.; Weaver, S.C.; Menachery, V.D. The Variant Gambit: COVID's Next Move. Cell Host Microbe 2021. [CrossRef] [PubMed]

432. Tse, H.; Lung, D.C.; Wong, S.C.-Y.; Ip, K.-F.; Wu, T.-C.; To, K.K.-W.; Kok, K.-H.; Yuen, K.-Y.; Choi, G.K.-Y. Emergence of a Severe Acute Respiratory Syndrome Coronavirus 2 virus variant with novel genomic architecture in Hong Kong. Clin. Infect. Dis. 2021. [CrossRef] [PubMed]

433. Altmann, D.M.; Boyton, R.J.; Beale, R. Immunity to SARS-CoV-2 variants of concern. Science 2021, 371, 1103-1104. [CrossRef]

434. Jackson, B.; Rambaut, A.; Pybus, O.G.; Robertson, D.L.; Connor, T.; Loman, N.J.; Consortium, T.C. Recombinant SARS-CoV-2 genomes involving lineage B.1.1.7 in the UK. Virological 2021. Available online: https://virological.org/t/recombinant-sars-cov2-genomes-involving-lineage-b-1-1-7-in-the-uk/ 658 (accessed on 3 June 2021).

435. De Oliveira, T.; Lutucuta, S.; Nkengasong, J.; Morais, J.; Paixão, J.P.; Neto, Z.; Afonso, P.; Miranda, J.; David, K.; Inglês, L.; et al. A novel variant of interest of SARS-CoV-2 with multiple spike mutations detected through travel surveillance in Africa. medRxiv 2021. [CrossRef]

436. Garcia, L.F. Immune Response, Inflammation, and the Clinical Spectrum of COVID-19. Front. Immunol. 2020, 11, 1441. [CrossRef]

437. Toor, S.M.; Saleh, R.; Sasidharan Nair, V.; Taha, R.Z.; Elkord, E. T-cell responses and therapies against SARS-CoV-2 infection. Immunology 2021, 162, 30-43. [CrossRef]

438. Combes, A.J.; Courau, T.; Kuhn, N.F.; Hu, K.H.; Ray, A.; Chen, W.S.; Chew, N.W.; Cleary, S.J.; Kushnoor, D.; Reeder, G.C.; et al. Global absence and targeting of protective immune states in severe COVID-19. Nature 2021, 591, 124-130. [CrossRef] [PubMed]

439. Blanco-Melo, D.; Nilsson-Payant, B.E.; Liu, W.C.; Uhl, S.; Hoagland, D.; Moller, R.; Jordan, T.X.; Oishi, K.; Panis, M.; Sachs, D.; et al. Imbalanced Host Response to SARS-CoV-2 Drives Development of COVID-19. Cell 2020. [CrossRef]

440. Gao, L.; Zhou, J.; Yang, S.; Wang, L.; Chen, X.; Yang, Y.; Li, R.; Pan, Z.; Zhao, J.; Li, Z.; et al. The dichotomous and incomplete adaptive immunity in COVID-19 patients with different disease severity. Signal. Transduct. Target. Ther. 2021, 6, 113. [CrossRef] [PubMed]

441. Migueles, S.A.; Connors, M. Success and failure of the cellular immune response against HIV-1. Nat. Immunol. 2015, 16, 563-570. [CrossRef] [PubMed]

442. Quinti, I.; Lougaris, V.; Milito, C.; Cinetto, F.; Pecoraro, A.; Mezzaroma, I.; Mastroianni, C.M.; Turriziani, O.; Bondioni, M.P.; Filippini, M.; et al. A possible role for B cells in COVID-19? Lesson from patients with agammaglobulinemia. J. Allergy Clin. Immunol. 2020, 146, 211-213.e4. [CrossRef]

443. Grifoni, A.; Weiskopf, D.; Ramirez, S.I.; Mateus, J.; Dan, J.M.; Moderbacher, C.R.; Rawlings, S.A.; Sutherland, A.; Premkumar, L.; Jadi, R.S.; et al. Targets of T Cell Responses to SARS-CoV-2 Coronavirus in Humans with COVID-19 Disease and Unexposed Individuals. Cell 2020, 181, 1489-1501.e15. [CrossRef] [PubMed]

444. Sekine, T.; Perez-Potti, A.; Rivera-Ballesteros, O.; Stralin, K.; Gorin, J.B.; Olsson, A.; Llewellyn-Lacey, S.; Kamal, H.; Bogdanovic, G.; Muschiol, S.; et al. Robust T Cell Immunity in Convalescent Individuals with Asymptomatic or Mild COVID-19. Cell 2020, 183, 158-168.e14. [CrossRef]

445. Streeck, H.; Nixon, D.F. T cell immunity in acute HIV-1 infection. J. Infect. Dis. 2010, 202 (Suppl. S2), S302-S308. [CrossRef]

446. Tarke, A.; Sidney, J.; Kidd, C.K.; Dan, J.M.; Ramirez, S.I.; Yu, E.D.; Mateus, J.; da Silva Antunes, R.; Moore, E.; Rubiro, P.; et al. Comprehensive analysis of T cell immunodominance and immunoprevalence of SARS-CoV-2 epitopes in COVID-19 cases. Cell Rep. Med. 2021, 2, 100204. [CrossRef] [PubMed]

447. Vardhana, S.A.; Wolchok, J.D. The many faces of the anti-COVID immune response. J. Exp. Med. 2020, 217. [CrossRef]

448. Tan, A.T.; Linster, M.; Tan, C.W.; Le Bert, N.; Chia, W.N.; Kunasegaran, K.; Zhuang, Y.; Tham, C.Y.L.; Chia, A.; Smith, G.J.D.; et al. Early induction of functional SARS-CoV-2-specific T cells associates with rapid viral clearance and mild disease in COVID-19 patients. Cell Rep. 2021, 34, 108728. [CrossRef] [PubMed] 
449. Bergamaschi, L.; Mescia, F.; Turner, L.; Hanson, A.L.; Kotagiri, P.; Dunmore, B.J.; Ruffieux, H.; De Sa, A.; Huhn, O.; Morgan, M.D.; et al. Longitudinal analysis reveals that delayed bystander CD8+ T cell activation and early immune pathology distinguish severe COVID-19 from mild disease. Immunity 2021. [CrossRef]

450. Renner, K.; Schwittay, T.; Chaabane, S.; Gottschling, J.; Muller, C.; Tiefenbock, C.; Salewski, J.N.; Winter, F.; Buchtler, S.; Balam, S.; et al. Severe T cell hyporeactivity in ventilated COVID-19 patients correlates with prolonged virus persistence and poor outcomes. Nat. Commun. 2021, 12, 3006. [CrossRef]

451. Wauters, E.; Van Mol, P.; Garg, A.D.; Jansen, S.; Van Herck, Y.; Vanderbeke, L.; Bassez, A.; Boeckx, B.; Malengier-Devlies, B.; Timmerman, A.; et al. Discriminating mild from critical COVID-19 by innate and adaptive immune single-cell profiling of bronchoalveolar lavages. Cell Res. 2021, 31, 272-290. [CrossRef]

452. Grau-Exposito, J.; Sanchez-Gaona, N.; Massana, N.; Suppi, M.; Astorga-Gamaza, A.; Perea, D.; Rosado, J.; Falco, A.; Kirkegaard, C.; Torrella, A.; et al. Peripheral and lung resident memory T cell responses against SARS-CoV-2. Nat. Commun. 2021, 12, 3010. [CrossRef]

453. Rydyznski Moderbacher, C.; Ramirez, S.I.; Dan, J.M.; Grifoni, A.; Hastie, K.M.; Weiskopf, D.; Belanger, S.; Abbott, R.K.; Kim, C.; Choi, J.; et al. Antigen-Specific Adaptive Immunity to SARS-CoV-2 in Acute COVID-19 and Associations with Age and Disease Severity. Cell 2020, 183, 996-1012.e19. [CrossRef] [PubMed]

454. Zhao, Q.; Meng, M.; Kumar, R.; Wu, Y.; Huang, J.; Deng, Y.; Weng, Z.; Yang, L. Lymphopenia is associated with severe coronavirus disease 2019 (COVID-19) infections: A systemic review and meta-analysis. Int. J. Infect. Dis. 2020, 96, 131-135. [CrossRef] [PubMed]

455. Nile, S.H.; Nile, A.; Qiu, J.; Li, L.; Jia, X.; Kai, G. COVID-19: Pathogenesis, cytokine storm and therapeutic potential of interferons. Cytokine Growth Factor Rev. 2020, 53, 66-70. [CrossRef] [PubMed]

456. Tan, L.; Wang, Q.; Zhang, D.; Ding, J.; Huang, Q.; Tang, Y.Q.; Wang, Q.; Miao, H. Lymphopenia predicts disease severity of COVID-19: A descriptive and predictive study. Signal. Transduct. Target 2020, 5, 33. [CrossRef] [PubMed]

457. Liao, M.; Liu, Y.; Yuan, J.; Wen, Y.; Xu, G.; Zhao, J.; Cheng, L.; Li, J.; Wang, X.; Wang, F.; et al. Single-cell landscape of bronchoalveolar immune cells in patients with COVID-19. Nat. Med. 2020, 26, 842-844. [CrossRef]

458. Wyllie, D.; Mulchandani, R.; Jones, H.E.; Taylor-Phillips, S.; Brooks, T.; Charlett, A.; Ades, A.E.; Makin, A.; Oliver, I.; Moore, P.; et al. SARS-CoV-2 responsive T cell numbers are associated with protection from COVID-19: A prospective cohort study in keyworkers. medRxiv 2020. [CrossRef]

459. Weiskopf, D.; Schmitz, K.S.; Raadsen, M.P.; Grifoni, A.; Okba, N.M.A.; Endeman, H.; van den Akker, J.P.C.; Molenkamp, R.; Koopmans, M.P.G.; van Gorp, E.C.M.; et al. Phenotype and kinetics of SARS-CoV-2-specific T cells in COVID-19 patients with acute respiratory distress syndrome. Sci. Immunol. 2020, 5. [CrossRef]

460. Mathew, D.; Giles, J.R.; Baxter, A.E.; Oldridge, D.A.; Greenplate, A.R.; Wu, J.E.; Alanio, C.; Kuri-Cervantes, L.; Pampena, M.B.; D'Andrea, K.; et al. Deep immune profiling of COVID-19 patients reveals distinct immunotypes with therapeutic implications. Science 2020, 369. [CrossRef]

461. Mazzoni, A.; Salvati, L.; Maggi, L.; Capone, M.; Vanni, A.; Spinicci, M.; Mencarini, J.; Caporale, R.; Peruzzi, B.; Antonelli, A.; et al. Impaired immune cell cytotoxicity in severe COVID-19 is IL-6 dependent. J. Clin. Invest. 2020, 130, 4694-4703. [CrossRef]

462. Chen, G.; Wu, D.; Guo, W.; Cao, Y.; Huang, D.; Wang, H.; Wang, T.; Zhang, X.; Chen, H.; Yu, H.; et al. Clinical and immunological features of severe and moderate coronavirus disease 2019. J. Clin. Invest. 2020, 130, 2620-2629. [CrossRef] [PubMed]

463. Low, J.S.; Vaqueirinho, D.; Mele, F.; Foglierini, M.; Jerak, J.; Perotti, M.; Jarrossay, D.; Jovic, S.; Perez, L.; Cacciatore, R.; et al. Clonal analysis of immunodominance and cross-reactivity of the CD4 T cell response to SARS-CoV-2. Science 2021. [CrossRef]

464. Lambotte, O.; Boufassa, F.; Madec, Y.; Nguyen, A.; Goujard, C.; Meyer, L.; Rouzioux, C.; Venet, A.; Oelfraissy, J.F. HIV controllers: A homogeneous group of HIV-1-infected patients with spontaneous control of viral replication. Clin. Infect. Dis. 2005, 41, 1053-1056. [CrossRef]

465. Lefrère, J.J.; Mariotti, M.; Morand-Joubert, L.; Thauvin, M.; Roudot-Thoraval, F. Plasma Human Immunodeficiency Virus RNA Below 40 Copies/mL Is Rarein Untreated Persons Even in the First Years of Infection. J. Infect. Dis. 1999, 180, 526-529. [CrossRef] [PubMed]

466. Migueles, S.A.; Connors, M. Long-term nonprogressive disease among untreated HIV-infected individuals clinical implications of understanding immune control of HIV. JAMA J. Am. Med Assoc. 2010, 304, 194-201. [CrossRef] [PubMed]

467. Phetsouphanh, C.; Xu, Y.; Zaunders, J. CD4 T Cells Mediate Both Positive and Negative Regulation of the Immune Response to HIV Infection: Complex Role of T Follicular Helper Cells and Regulatory T Cells in Pathogenesis. Front. Immunol. 2015, 5. [CrossRef] [PubMed]

468. Lin, L.; Finak, G.; Ushey, K.; Seshadri, C.; Hawn, T.R.; Frahm, N.; Scriba, T.J.; Mahomed, H.; Hanekom, W.; Bart, P.A.; et al. COMPASS identifies T-cell subsets correlated with clinical outcomes. Nat. Biotechnol. 2015, 33, 610-616. [CrossRef]

469. Borrow, P.; Lewicki, H.; Hahn, B.H.; Shaw, G.M.; Oldstone, M.B. Virus-specific CD8+ cytotoxic T-lymphocyte activity associated with control of viremia in primary human immunodeficiency virus type 1 infection. J. Virol. 1994, 68, 6103-6110. [CrossRef]

470. Koup, R.A.; Safrit, J.T.; Cao, Y.; Andrews, C.A.; McLeod, G.; Borkowsky, W.; Farthing, C.; Ho, D.D. Temporal association of cellular immune responses with the initial control of viremia in primary human immunodeficiency virus type 1 syndrome. $J$. Virol. 1994, 68, 4650-4655. [CrossRef] 
471. Ogg, G.S.; Jin, X.; Bonhoeffer, S.; Dunbar, P.R.; Nowak, M.A.; Monard, S.; Segal, J.P.; Cao, Y.; Rowland-Jones, S.L.; Cerundolo, V.; et al. Quantitation of HIV-1-specific cytotoxic T lymphocytes and plasma load of viral RNA. Science 1998, 279, $2103-2106$. [CrossRef] [PubMed]

472. Wilson, J.D.K.; Ogg, G.S.; Allen, R.L.; Davis, C.; Shaunak, S.; Downie, J.; Dyer, W.; Workman, C.; Sullivan, J.S.; McMichael, A.J.; et al. Direct visualization of HIV-1-specific cytotoxic T lymphocytes during primary infection. AIDS 2000. [CrossRef] [PubMed]

473. Day, C.L.; Kaufmann, D.E.; Kiepiela, P.; Brown, J.A.; Moodley, E.S.; Reddy, S.; Mackey, E.W.; Miller, J.D.; Leslie, A.J.; DePierres, C.; et al. PD-1 expression on HIV-specific T cells is associated with T-cell exhaustion and disease progression. Nature 2006, 443, 350-354. [CrossRef]

474. Veenhuis, R.T.; Blankson, J.N. The Antiviral Immune Response and Its Impact on the HIV-1 Reservoir. In HIV-1 Latency; Springer: Cham, Switzerland, 2018; Volume 417, pp. 43-67.

475. Almeida, J.R.; Price, D.A.; Papagno, L.; Arkoub, Z.A.; Sauce, D.; Bornstein, E.; Asher, T.E.; Samri, A.; Schnuriger, A.; Theodorou, I.; et al. Superior control of HIV-1 replication by CD8+ T cells is reflected by their avidity, polyfunctionality, and clonal turnover. J. Exp. Med. 2007, 204, 2473-2485. [CrossRef]

476. Betts, M.R.; Nason, M.C.; West, S.M.; De Rosa, S.C.; Migueles, S.A.; Abraham, J.; Lederman, M.M.; Benito, J.M.; Goepfert, P.A.; Connors, M.; et al. HIV nonprogressors preferentially maintain highly functional HIV-specific CD8+ T cells. Blood 2006, 107, 4781-4789. [CrossRef]

477. Ferre, A.L.; Hunt, P.W.; Critchfield, J.W.; Young, D.H.; Morris, M.M.; Garcia, J.C.; Pollard, R.B.; Yee, H.F.; Martin, J.N.; Deeks, S.G.; et al. Mucosal immune responses to HIV-1 in elite controllers: A potential correlate of immune control. Blood 2009, 113, 3978-3989. [CrossRef]

478. Brenchley, J.M.; Schacker, T.W.; Ruff, L.E.; Price, D.A.; Taylor, J.H.; Beilman, G.J.; Nguyen, P.L.; Khoruts, A.; Larson, M.; Haase, A.T.; et al. CD4+ T cell depletion during all stages of HIV disease occurs predominantly in the gastrointestinal tract. J. Exp. Med. 2004, 200, 749-759. [CrossRef] [PubMed]

479. Mattapallil, J.J.; Douek, D.C.; Hill, B.; Nishimura, Y.; Martin, M.; Roederer, M. Massive infection and loss of memory CD4+ T cells in multiple tissues during acute SIV infection. Nature 2005, 434, 1093-1097. [CrossRef]

480. Veazey, R.S.; DeMaria, M.A.; Chalifoux, L.V.; Shvetz, D.E.; Pauley, D.R.; Knight, H.L.; Rosenzweig, M.; Johnson, R.P.; Desrosiers, R.C.; Lackner, A.A. Gastrointestinal tract as a major site of CD4+ T cell depletion and viral replication in SIV infection. Science 1998, 280, 427-431. [CrossRef] [PubMed]

481. Zheng, H.Y.; Zhang, M.; Yang, C.X.; Zhang, N.; Wang, X.C.; Yang, X.P.; Dong, X.Q.; Zheng, Y.T. Elevated exhaustion levels and reduced functional diversity of $\mathrm{T}$ cells in peripheral blood may predict severe progression in COVID-19 patients. Cell Mol. Immunol. 2020, 17, 541-543. [CrossRef] [PubMed]

482. Rha, M.S.; Jeong, H.W.; Ko, J.H.; Choi, S.J.; Seo, I.H.; Lee, J.S.; Sa, M.; Kim, A.R.; Joo, E.J.; Ahn, J.Y.; et al. PD-1-Expressing SARS-CoV-2-Specific CD8(+) T Cells Are Not Exhausted, but Functional in Patients with COVID-19. Immunity 2021, 54, 44-52.e3. [CrossRef]

483. Liu, C.; Martins, A.J.; Lau, W.W.; Rachmaninoff, N.; Chen, J.; Imberti, L.; Mostaghimi, D.; Fink, D.L.; Burbelo, P.D.; Dobbs, K.; et al. Time-resolved systems immunology reveals a late juncture linked to fatal COVID-19. Cell 2021. [CrossRef]

484. Kusnadi, A.; Ramirez-Suastegui, C.; Fajardo, V.; Chee, S.J.; Meckiff, B.J.; Simon, H.; Pelosi, E.; Seumois, G.; Ay, F.; Vijayanand, P.; et al. Severely ill COVID-19 patients display impaired exhaustion features in SARS-CoV-2-reactive CD8(+) T cells. Sci. Immunol. 2021, 6. [CrossRef]

485. Hellerstein, M. What are the roles of antibodies versus a durable, high quality T-cell response in protective immunity against SARS-CoV-2? Vaccine X 2020, 6, 100076. [CrossRef] [PubMed]

486. Tarke, A.; Sidney, J.; Methot, N.; Zhang, Y.; Dan, J.M.; Goodwin, B.; Rubiro, P.; Sutherland, A.; da Silva Antunes, R.; Frazier, A.; et al. Negligible impact of SARS-CoV-2 variants on CD4+ and CD8+ T cell reactivity in COVID-19 exposed donors and vaccinees. bioRxiv 2021. [CrossRef]

487. Thevarajan, I.; Nguyen, T.H.O.; Koutsakos, M.; Druce, J.; Caly, L.; van de Sandt, C.E.; Jia, X.; Nicholson, S.; Catton, M.; Cowie, B.; et al. Breadth of concomitant immune responses prior to patient recovery: A case report of non-severe COVID-19. Nat. Med. 2020, 26, 453-455. [CrossRef]

488. Juno, J.A.; Tan, H.X.; Lee, W.S.; Reynaldi, A.; Kelly, H.G.; Wragg, K.; Esterbauer, R.; Kent, H.E.; Batten, C.J.; Mordant, F.L.; et al. Humoral and circulating follicular helper T cell responses in recovered patients with COVID-19. Nat. Med. 2020, 26, 1428-1434. [CrossRef]

489. Scheid, J.F.; Barnes, C.O.; Eraslan, B.; Hudak, A.; Keeffe, J.R.; Cosimi, L.A.; Brown, E.M.; Muecksch, F.; Weisblum, Y.; Zhang, S.; et al. B cell genomics behind cross-neutralization of SARS-CoV-2 variants and SARS-CoV. Cell 2021. [CrossRef]

490. Lineburg, K.E.; Srihari, S.; Altaf, M.; Swaminathan, S.; Panikkar, A.; Raju, J.; Crooks, P.; Ambalathingal, G.R.; Martins, J.P.; Matthews, K.K.; et al. Rapid detection of SARS-CoV-2-specific memory T-cell immunity in recovered COVID-19 cases. Clin. Transl. Immunol. 2020, 9, e1219. [CrossRef] [PubMed]

491. Hartley, G.E.; Edwards, E.S.J.; Aui, P.M.; Varese, N.; Stojanovic, S.; McMahon, J.; Peleg, A.Y.; Boo, I.; Drummer, H.E.; Hogarth, P.M.; et al. Rapid generation of durable B cell memory to SARS-CoV-2 spike and nucleocapsid proteins in COVID-19 and convalescence. Sci. Immunol. 2020, 5. [CrossRef] 
492. Sokal, A.; Chappert, P.; Barba-Spaeth, G.; Roeser, A.; Fourati, S.; Azzaoui, I.; Vandenberghe, A.; Fernandez, I.; Meola, A.; BouvierAlias, M.; et al. Maturation and persistence of the anti-SARS-CoV-2 memory B cell response. Cell 2021, 184, 1201-1213.e14. [CrossRef]

493. Turner, J.S.; Kim, W.; Kalaidina, E.; Goss, C.W.; Rauseo, A.M.; Schmitz, A.J.; Hansen, L.; Haile, A.; Klebert, M.K.; Pusic, I.; et al. SARS-CoV-2 infection induces long-lived bone marrow plasma cells in humans. Nature 2021, -4. [CrossRef]

494. Abayasingam, A.; Balachandran, H.; Agapiou, D.; Hammoud, M.; Rodrigo, C.; Keoshkerian, E.; Li, H.; Brasher, N.A.; Christ, D.; Rouet, R.; et al. Long-term persistence of RBD-positive memory B cells encoding neutralising antibodies in SARS-CoV-2 infection. Cell Rep. Med. 2021. [CrossRef] [PubMed]

495. Kardava, L.; Moir, S. B-Cell Abnormalities in HIV-1 Infection: Roles for IgG3 and T-bet. J. Clin. Investig. 2019, 14, 240-245. [CrossRef] [PubMed]

496. Noto, A.; Pantaleo, G. B-cell abnormalities and impact on antibody response in HIV infection. Curr. Opin. HIV AIDS 2017, 12, 203-208. [CrossRef] [PubMed]

497. Lane, H.C.; Masur, H.; Edgar, L.C.; Whalen, G.; Rook, A.H.; Fauci, A.S. Abnormalities of B-Cell Activation and Immunoregulation in Patients with the Acquired Immunodeficiency Syndrome. N. Engl. J. Med. 1983, 309, 453-458. [CrossRef]

498. Buckner, C.M.; Kardava, L.; Zhang, X.; Gittens, K.; Justement, J.S.; Kovacs, C.; McDermott, A.B.; Li, Y.; Sajadi, M.M.; Chun, T.-W.; et al. Maintenance of HIV-Specific Memory B-Cell Responses in Elite Controllers Despite Low Viral Burdens. J. Infect. Dis. 2016, 214, 390-398. [CrossRef] [PubMed]

499. Kardava, L.; Moir, S.; Shah, N.; Wang, W.; Wilson, R.; Buckner, C.M.; Santich, B.H.; Kim, L.J.Y.; Spurlin, E.E.; Nelson, A.K.; et al. Abnormal B cell memory subsets dominate HIV-specific responses in infected individuals. J. Clin. Invest. 2014, 124, $3252-3262$. [CrossRef]

500. De Milito, A.; Nilsson, A.; Titanji, K.; Thorstensson, R.; Reizenstein, E.; Narita, M.; Grutzmeier, S.; Sönnerborg, A.; Chiodi, F. Mechanisms of hypergammaglobulinemia and impaired antigen-specific humoral immunity in HIV-1 infection. Blood 2004, 103, 2180-2186. [CrossRef]

501. Schnittman, S.M.; Lane, H.C.; Higgins, S.E.; Folks, T.; Fauci, A.S. Direct polyclonal activation of human B lymphocytes by the acquired immune deficiency syndrome virus. Science 1986, 233, 1084-1086. [CrossRef] [PubMed]

502. Shirai, A.; Cosentino, M.; Leitman-Klinman, S.F.; Klinman, D.M. Human immunodeficiency virus infection induces both polyclonal and virus-specific B cell activation. J. Clin. Invest. 1992, 89, 561-566. [CrossRef]

503. Cubas, R.A.; Mudd, J.C.; Savoye, A.L.; Perreau, M.; Van Grevenynghe, J.; Metcalf, T.; Connick, E.; Meditz, A.; Freeman, G.J.; Abesada-Terk, G.; et al. Inadequate T follicular cell help impairs B cell immunity during HIV infection. Nat. Med. 2013, 19, 494-499. [CrossRef]

504. Gasper-Smith, N.; Crossman, D.M.; Whitesides, J.F.; Mensali, N.; Ottinger, J.S.; Plonk, S.G.; Moody, M.A.; Ferrari, G.; Weinhold, K.J.; Miller, S.E.; et al. Induction of Plasma (TRAIL), TNFR-2, Fas Ligand, and Plasma Microparticles after Human Immunodeficiency Virus Type 1 (HIV-1) Transmission: Implications for HIV-1 Vaccine Design. J. Virol. 2008, 82, 7700-7710. [CrossRef]

505. Levesque, M.C.; Moody, M.A.; Hwang, K.-K.; Marshall, D.J.; Whitesides, J.F.; Amos, J.D.; Gurley, T.C.; Allgood, S.; Haynes, B.B.; Vandergrift, N.A.; et al. Polyclonal B Cell Differentiation and Loss of Gastrointestinal Tract Germinal Centers in the Earliest Stages of HIV-1 Infection. PLoS Med. 2009, 6, e1000107. [CrossRef]

506. Muro-Cacho, C.A.; Pantaleo, G.; Fauci, A.S. Analysis of apoptosis in lymph nodes of HIV-infected persons. Intensity of apoptosis correlates with the general state of activation of the lymphoid tissue and not with stage of disease or viral burden. J. Immunol. 1995, 154, 5555-5566.

507. Havenar-Daughton, C.; Carnathan, D.G.; Torrents de la Peña, A.; Pauthner, M.; Briney, B.; Reiss, S.M.; Wood, J.S.; Kaushik, K.; van Gils, M.J.; Rosales, S.L.; et al. Direct Probing of Germinal Center Responses Reveals Immunological Features and Bottlenecks for Neutralizing Antibody Responses to HIV Env Trimer. Cell Rep. 2016, 17, 2195-2209. [CrossRef]

508. Jiang, W.; Lederman, M.M.; Mohner, R.J.; Rodriguez, B.; Nedrich, T.M.; Harding, C.V.; Sieg, S.F. Impaired Naive and Memory B-Cell Responsiveness to TLR9 Stimulation in Human Immunodeficiency Virus Infection. J. Virol. 2008, 82, 7837-7845. [CrossRef] [PubMed]

509. Malaspina, A.; Moir, S.; DiPoto, A.C.; Ho, J.; Wang, W.; Roby, G.; O’Shea, M.A.; Fauci, A.S. CpG Oligonucleotides Enhance Proliferative and Effector Responses of B Cells in HIV-Infected Individuals. J. Immunol. 2008, 181, 1199-1206. [CrossRef] [PubMed]

510. Cubas, R.; van Grevenynghe, J.; Wills, S.; Kardava, L.; Santich, B.H.; Buckner, C.M.; Muir, R.; Tardif, V.; Nichols, C.; Procopio, F.; et al. Reversible Reprogramming of Circulating Memory T Follicular Helper Cell Function during Chronic HIV Infection. J. Immunol. 2015, 195, 5625-5636. [CrossRef]

511. Chevrier, S.; Zurbuchen, Y.; Cervia, C.; Adamo, S.; Raeber, M.E.; de Souza, N.; Sivapatham, S.; Jacobs, A.; Bachli, E.; Rudiger, A.; et al. A distinct innate immune signature marks progression from mild to severe COVID-19. Cell Rep. Med. 2021, 2, 100166. [CrossRef]

512. Feng, Z.; Diao, B.; Wang, R.; Wang, G.; Wang, C.; Tan, Y.; Liu, L.; Wang, C.; Liu, Y.; Liu, Y.; et al. The Novel Severe Acute Respiratory Syndrome Coronavirus 2 (SARS-CoV-2) Directly Decimates Human Spleens and Lymph Nodes. medRxiv 2020. [CrossRef] 
513. Szabo, P.A.; Dogra, P.; Gray, J.I.; Wells, S.B.; Connors, T.J.; Weisberg, S.P.; Krupska, I.; Matsumoto, R.; Poon, M.M.L.; Idzikowski, E.; et al. Longitudinal profiling of respiratory and systemic immune responses reveals myeloid cell-driven lung inflammation in severe COVID-19. Immunity 2021. [CrossRef] [PubMed]

514. Lavin, Y.; Mortha, A.; Rahman, A.; Merad, M. Regulation of macrophage development and function in peripheral tissues. Nat. Rev. Immunol. 2015, 15, 731-744. [CrossRef]

515. Behrens, E.M.; Koretzky, G.A. Review: Cytokine Storm Syndrome: Looking Toward the Precision Medicine Era. Arthritis Rheumatol. 2017, 69, 1135-1143. [CrossRef]

516. Mehta, P.; McAuley, D.F.; Brown, M.; Sanchez, E.; Tattersall, R.S.; Manson, J.J. COVID-19: Consider cytokine storm syndromes and immunosuppression. Lancet 2020, 395, 1033-1034. [CrossRef]

517. Wu, C.; Chen, X.; Cai, Y.; Xia, J.; Zhou, X.; Xu, S.; Huang, H.; Zhang, L.; Zhou, X.; Du, C.; et al. Risk Factors Associated With Acute Respiratory Distress Syndrome and Death in Patients With Coronavirus Disease 2019 Pneumonia in Wuhan, China. JAMA Intern. Med. 2020, 180, 934-943. [CrossRef]

518. Aguiar, D.; Lobrinus, J.A.; Schibler, M.; Fracasso, T.; Lardi, C. Inside the lungs of COVID-19 disease. Int. J. Leg. Med. 2020, 134, 1271-1274. [CrossRef] [PubMed]

519. Carsana, L.; Sonzogni, A.; Nasr, A.; Rossi, R.S.; Pellegrinelli, A.; Zerbi, P.; Rech, R.; Colombo, R.; Antinori, S.; Corbellino, M.; et al. Pulmonary post-mortem findings in a series of COVID-19 cases from northern Italy: A two-centre descriptive study. Lancet Infect. Dis. 2020, 20, 1135-1140. [CrossRef]

520. Ural, B.B.; Yeung, S.T.; Damani-Yokota, P.; Devlin, J.C.; de Vries, M.; Vera-Licona, P.; Samji, T.; Sawai, C.M.; Jang, G.; Perez, O.A.; et al. Identification of a nerve-associated, lung-resident interstitial macrophage subset with distinct localization and immunoregulatory properties. Sci. Immunol. 2020, 5. [CrossRef] [PubMed]

521. Chua, R.L.; Lukassen, S.; Trump, S.; Hennig, B.P.; Wendisch, D.; Pott, F.; Debnath, O.; Thurmann, L.; Kurth, F.; Volker, M.T.; et al. COVID-19 severity correlates with airway epithelium-immune cell interactions identified by single-cell analysis. Nat. Biotechnol. 2020, 38, 970-979. [CrossRef] [PubMed]

522. Grant, R.A.; Morales-Nebreda, L.; Markov, N.S.; Swaminathan, S.; Querrey, M.; Guzman, E.R.; Abbott, D.A.; Donnelly, H.K.; Donayre, A.; Goldberg, I.A.; et al. Circuits between infected macrophages and T cells in SARS-CoV-2 pneumonia. Nature 2021, 590, 635-641. [CrossRef]

523. Channappanavar, R.; Fehr, A.R.; Zheng, J.; Wohlford-Lenane, C.; Abrahante, J.E.; Mack, M.; Sompallae, R.; McCray, P.B., Jr.; Meyerholz, D.K.; Perlman, S. IFN-I response timing relative to virus replication determines MERS coronavirus infection outcomes. J. Clin. Invest. 2019, 129, 3625-3639. [CrossRef]

524. Zhou, J.; Chu, H.; Li, C.; Wong, B.H.; Cheng, Z.S.; Poon, V.K.; Sun, T.; Lau, C.C.; Wong, K.K.; Chan, J.Y.; et al. Active replication of Middle East respiratory syndrome coronavirus and aberrant induction of inflammatory cytokines and chemokines in human macrophages: Implications for pathogenesis. J. Infect. Dis. 2014, 209, 1331-1342. [CrossRef]

525. Giamarellos-Bourboulis, E.J.; Netea, M.G.; Rovina, N.; Akinosoglou, K.; Antoniadou, A.; Antonakos, N.; Damoraki, G.; Gkavogianni, T.; Adami, M.E.; Katsaounou, P.; et al. Complex Immune Dysregulation in COVID-19 Patients with Severe Respiratory Failure. Cell Host Microbe 2020, 27, 992-1000.e3. [CrossRef] [PubMed]

526. Anzinger, J.J.; Butterfield, T.R.; Angelovich, T.A.; Crowe, S.M.; Palmer, C.S. Monocytes as Regulators of Inflammation and HIV-Related Comorbidities during cART; J. Immunol. Res. 2014, 2014, 56981. [CrossRef] [PubMed]

527. Kruize, Z.; Kootstra, N.A. The Role of Macrophages in HIV-1 Persistence and Pathogenesis. Frontiers Microbiol. 2019, 10, 2828. [CrossRef] [PubMed]

528. Teer, E.; Joseph, D.E.; Glashoff, R.H.; Faadiel Essop, M. Monocyte/Macrophage-Mediated Innate Immunity in HIV-1 Infection: From Early Response to Late Dysregulation and Links to Cardiovascular Diseases Onset. Virol. Sin. 2021. [CrossRef]

529. Wong, M.E.; Jaworowski, A.; Hearps, A.C. The HIV reservoir in monocytes and macrophages. Front. Immunol. 2019, 10, 1435. [CrossRef]

530. Ellery, P.J.; Tippett, E.; Chiu, Y.-L.; Paukovics, G.; Cameron, P.U.; Solomon, A.; Lewin, S.R.; Gorry, P.R.; Jaworowski, A.; Greene, W.C.; et al. The CD16 + Monocyte Subset Is More Permissive to Infection and Preferentially Harbors HIV-1 In Vivo. J. Immunol. 2007, 178, 6581-6589. [CrossRef]

531. Sonza, S.; Mutimer, H.P.; Oelrichs, R.; Jardine, D.; Harvey, K.; Dunne, A.; Purcell, D.F.; Birch, C.; Crowe, S.M. Monocytes harbour replication-competent, non-latent HIV-1 in patients on highly active antiretroviral therapy. AIDS 2001, 15, 17-22. [CrossRef]

532. Zhu, T.; Muthui, D.; Holte, S.; Nickle, D.; Feng, F.; Brodie, S.; Hwangbo, Y.; Mullins, J.I.; Corey, L. Evidence for Human Immunodeficiency Virus Type 1 Replication In Vivo in CD14+ Monocytes and Its Potential Role as a Source of Virus in Patients on Highly Active Antiretroviral Therapy. J. Virol. 2002, 76, 707-716. [CrossRef] [PubMed]

533. Duncan, C.J.A.; Russell, R.A.; Sattentau, Q.J. High multiplicity HIV-1 cell-to-cell transmission from macrophages to CD4+ T cells limits antiretroviral efficacy. AIDS 2013, 27, 2201-2206. [CrossRef]

534. Rappaport, J.; Volsky, D.J. Role of the macrophage in HIV-associated neurocognitive disorders and other comorbidities in patients on effective antiretroviral treatment. J. Neurovirol. 2015, 21, 235-241. [CrossRef]

535. Cribbs, S.K.; Lennox, J.; Caliendo, A.M.; Brown, L.A.; Guidot, D.M. Healthy HIV-1-infected individuals on highly active antiretroviral therapy harbor HIV-1 in their alveolar macrophages. AIDS Res. Hum. Retrovir. 2015, 31, 64-70. [CrossRef] 
536. Kandathil, A.J.; Sugawara, S.; Goyal, A.; Durand, C.M.; Quinn, J.; Sachithanandham, J.; Cameron, A.M.; Bailey, J.R.; Perelson, A.S.; Balagopal, A. No recovery of replication-competent HIV-1 from human liver macrophages. J. Clin. Invest. 2018, 128, 4501-4509. [CrossRef]

537. Lokugamage, K.G.; Hage, A.; de Vries, M.; Valero-Jimenez, A.M.; Schindewolf, C.; Dittmann, M.; Rajsbaum, R.; Menachery, V.D. Type I Interferon Susceptibility Distinguishes SARS-CoV-2 from SARS-CoV. J. Virol. 2020, 94. [CrossRef]

538. Lahaye, X.; Gentili, M.; Silvin, A.; Conrad, C.; Picard, L.; Jouve, M.; Zueva, E.; Maurin, M.; Nadalin, F.; Knott, G.J.; et al. NONO Detects the Nuclear HIV Capsid to Promote cGAS-Mediated Innate Immune Activation. Cell 2018, 175, 488-501.e22. [CrossRef] [PubMed]

539. Yoh, S.M.; Schneider, M.; Seifried, J.; Soonthornvacharin, S.; Akleh, R.E.; Olivieri, K.C.; De Jesus, P.D.; Ruan, C.; De Castro, E.; Ruiz, P.A.; et al. PQBP1 is a proximal sensor of the cGAS-dependent innate response to HIV-1. Cell 2015, 161, 1293-1305. [CrossRef] [PubMed]

540. Oran, D.P.; Topol, E.J. Prevalence of Asymptomatic SARS-CoV-2 Infection: A Narrative Review. Ann. Intern. Med. 2020, 173, 362-367. [CrossRef]

541. Ciotti, M.; Angeletti, S.; Minieri, M.; Giovannetti, M.; Benvenuto, D.; Pascarella, S.; Sagnelli, C.; Bianchi, M.; Bernardini, S.; Ciccozzi, M. COVID-19 Outbreak: An Overview. Chemotherapy 2019, 64, 215-223. [CrossRef]

542. Casadevall, A.; Pirofski, L.A. In fatal COVID-19, the immune response can control the virus but kill the patient. Proc. Natl. Acad. Sci. USA 2020, 117, 30009-30011. [CrossRef] [PubMed]

543. Koutsakos, M.; Rowntree, L.C.; Hensen, L.; Chua, B.Y.; van de Sandt, C.E.; Habel, J.R.; Zhang, W.; Jia, X.; Kedzierski, L.; Ashhurst, T.M.; et al. Integrated immune dynamics define correlates of COVID-19 severity and antibody responses. Cell Rep. Med. 2021, 2, 100208. [CrossRef] [PubMed]

544. Schultze, J.L.; Aschenbrenner, A.C. COVID-19 and the human innate immune system. Cell 2021. [CrossRef]

545. Ferreira-Gomes, M.; Kruglov, A.; Durek, P.; Heinrich, F.; Tizian, C.; Heinz, G.A.; Pascual-Reguant, A.; Du, W.; Mothes, R.; Fan, C.; et al. SARS-CoV-2 in severe COVID-19 induces a TGF-beta-dominated chronic immune response that does not target itself. Nat. Commun. 2021, 12, 1961. [CrossRef] [PubMed]

546. Zhang, B.; Zhou, X.; Qiu, Y.; Song, Y.; Feng, F.; Feng, J.; Song, Q.; Jia, Q.; Wang, J. Clinical characteristics of 82 cases of death from COVID-19. PLoS ONE 2020, 15, e0235458. [CrossRef] [PubMed]

547. Zhou, Y.; Fu, B.; Zheng, X.; Wang, D.; Zhao, C.; Qi, Y.; Sun, R.; Tian, Z.; Xu, X.; Wei, H. Pathogenic T cells and inflammatory monocytes incite inflammatory storm in severe COVID-19 patients. Natl. Sci. Rev. 2020. [CrossRef]

548. Coperchini, F.; Chiovato, L.; Croce, L.; Magri, F.; Rotondi, M. The cytokine storm in COVID-19: An overview of the involvement of the chemokine/chemokine-receptor system. Cytokine Growth Factor Rev. 2020, 53, 25-32. [CrossRef]

549. Toubiana, J.; Poirault, C.; Corsia, A.; Bajolle, F.; Fourgeaud, J.; Angoulvant, F.; Debray, A.; Basmaci, R.; Salvador, E.; Biscardi, S.; et al. Outbreak of Kawasaki disease in children during COVID-19 pandemic: A prospective observational study in Paris, France. medRxiv 2020. [CrossRef]

550. Chen, X.; Zhao, B.; Qu, Y.; Chen, Y.; Xiong, J.; Feng, Y.; Men, D.; Huang, Q.; Liu, Y.; Yang, B.; et al. Detectable Serum Severe Acute Respiratory Syndrome Coronavirus 2 Viral Load (RNAemia) Is Closely Correlated With Drastically Elevated Interleukin 6 Level in Critically Ill Patients With Coronavirus Disease 2019. Clin. Infect. Dis. 2020, 71, 1937-1942. [CrossRef] [PubMed]

551. Ruan, Q.; Yang, K.; Wang, W.; Jiang, L.; Song, J. Clinical predictors of mortality due to COVID-19 based on an analysis of data of 150 patients from Wuhan, China. Intensive Care Med. 2020, 46, 846-848. [CrossRef] [PubMed]

552. Xiong, Y.; Liu, Y.; Cao, L.; Wang, D.; Guo, M.; Jiang, A.; Guo, D.; Hu, W.; Yang, J.; Tang, Z.; et al. Transcriptomic characteristics of bronchoalveolar lavage fluid and peripheral blood mononuclear cells in COVID-19 patients. Emerg. Microbes Infect. 2020, 9 , 761-770. [CrossRef]

553. Stacey, A.R.; Norris, P.J.; Qin, L.; Haygreen, E.A.; Taylor, E.; Heitman, J.; Lebedeva, M.; DeCamp, A.; Li, D.; Grove, D.; et al. Induction of a Striking Systemic Cytokine Cascade prior to Peak Viremia in Acute Human Immunodeficiency Virus Type 1 Infection, in Contrast to More Modest and Delayed Responses in Acute Hepatitis B and C Virus Infections. J. Virol. 2009, 83, 3719-3733. [CrossRef] [PubMed]

554. Li, Q.; Estes, J.D.; Schlievert, P.M.; Duan, L.; Brosnahan, A.J.; Southern, P.J.; Reilly, C.S.; Peterson, M.L.; Schultz-Darken, N.; Brunner, K.G.; et al. Glycerol monolaurate prevents mucosal SIV transmission. Nature 2009, 458, 1034-1038. [CrossRef]

555. Boulware, D.R.; Hullsiek, K.H.; Puronen, C.E.; Rupert, A.; Baker, J.V.; French, M.A.; Bohjanen, P.R.; Novak, R.M.; Neaton, J.D.; Sereti, I. Higher Levels of CRP, D-dimer, IL-6, and Hyaluronic Acid Before Initiation of Antiretroviral Therapy (ART) Are Associated With Increased Risk of AIDS or Death. J. Infect. Dis. 2011, 203, 1637-1646. [CrossRef]

556. Hunt, P.W.; Sinclair, E.; Rodriguez, B.; Shive, C.; Clagett, B.; Funderburg, N.; Robinson, J.; Huang, Y.; Epling, L.; Martin, J.N.; et al. Gut epithelial barrier dysfunction and innate immune activation predict mortality in treated HIV infection. J. Infect. Dis. 2014, 210, 1228-1238. [CrossRef]

557. Justice, A.C.; Freiberg, M.S.; Tracy, R.; Kuller, L.; Tate, J.P.; Goetz, M.B.; Fiellin, D.A.; Vanasse, G.J.; Butt, A.A.; Rodriguez-Barradas, M.C.; et al. Does an index composed of clinical data reflect effects of inflammation, coagulation, and monocyte activation on mortality among those aging with HIV? Clin. Infect. Dis. 2012. [CrossRef]

558. Kalayjian, R.C.; Machekano, R.N.; Rizk, N.; Robbins, G.K.; Gandhi, R.T.; Rodriguez, B.A.; Pollard, R.B.; Lederman, M.M.; Landay, A. Pretreatment Levels of Soluble Cellular Receptors and Interleukin-6 Are Associated with HIV Disease Progression in Subjects Treated with Highly Active Antiretroviral Therapy. J. Infect. Dis. 2010, 201, 1796-1805. [CrossRef] 
559. Kuller, L.H.; Tracy, R.; Belloso, W.; Wit, S.D.; Drummond, F.; Lane, H.C.; Ledergerber, B.; Lundgren, J.; Neuhaus, J.; Nixon, D.; et al. Inflammatory and Coagulation Biomarkers and Mortality in Patients with HIV Infection. PLoS Med. 2008, 5, e203. [CrossRef]

560. Ledwaba, L.; Tavel, J.A.; Khabo, P.; Maja, P.; Qin, J.; Sangweni, P.; Liu, X.; Follmann, D.; Metcalf, J.A.; Orsega, S.; et al. Pre-ART Levels of Inflammation and Coagulation Markers Are Strong Predictors of Death in a South African Cohort with Advanced HIV Disease. PLoS ONE 2012, 7, e24243. [CrossRef] [PubMed]

561. Sandler, N.G.; Wand, H.; Roque, A.; Law, M.; Nason, M.C.; Nixon, D.E.; Pedersen, C.; Ruxrungtham, K.; Lewin, S.R.; Emery, S.; et al. Plasma Levels of Soluble CD14 Independently Predict Mortality in HIV Infection. J. Infect. Dis. 2011, 203, 780-790. [CrossRef] [PubMed]

562. Tien, P.C.; Choi, A.I.; Zolopa, A.R.; Benson, C.; Tracy, R.; Scherzer, R.; Bacchetti, P.; Shlipak, M.; Grunfeld, C. Inflammation and Mortality in HIV-Infected Adults: Analysis of the FRAM Study Cohort. JAIDS J. Acquir. Immune Defic. Syndr. 2010, 55, 316-322. [CrossRef]

563. Akira, S. TLR signaling. Curr Top. Microbiol. Immunol. 2006, 311, 1-16. [CrossRef]

564. Cheemarla, N.R.; Watkins, T.A.; Mihaylova, V.T.; Wang, B.; Zhao, D.; Wang, G.; Landry, M.L.; Foxman, E.F. Dynamic innate immune response determines susceptibility to SARS-CoV-2 infection and early replication kinetics. J. Exp. Med. 2021, 218. [CrossRef]

565. Schreiber, G. The molecular basis for differential type I interferon signaling. J. Biol. Chem. 2017, 292, 7285-7294. [CrossRef] [PubMed]

566. Haller, O.; Kochs, G.; Weber, F. The interferon response circuit: Induction and suppression by pathogenic viruses. Virology 2006, 344, 119-130. [CrossRef] [PubMed]

567. Rodriguez, J.J.; Parisien, J.P.; Horvath, C.M. Nipah virus V protein evades alpha and gamma interferons by preventing STAT1 and STAT2 activation and nuclear accumulation. J. Virol. 2002, 76, 11476-11483. [CrossRef]

568. Busnadiego, I.; Fernbach, S.; Pohl, M.O.; Karakus, U.; Huber, M.; Trkola, A.; Stertz, S.; Hale, B.G. Antiviral Activity of Type I, II, and III Interferons Counterbalances ACE2 Inducibility and Restricts SARS-CoV-2. mBio 2020, 11. [CrossRef]

569. Lei, X.; Dong, X.; Ma, R.; Wang, W.; Xiao, X.; Tian, Z.; Wang, C.; Wang, Y.; Li, L.; Ren, L.; et al. Activation and evasion of type I interferon responses by SARS-CoV-2. Nat. Commun. 2020, 11, 3810. [CrossRef]

570. Kim, M.-H.; Salloum, S.; Wang, J.Y.; Lai Ping, W.; Regan, J.; Lefteri, K.; Manickas-Hill, Z.; Gao, C.; Collection, M.C.-.; Team, P.; et al. Type I, II, and III interferon signatures correspond to COVID-19 disease severity. J. Infect. Dis. 2021. [CrossRef] [PubMed]

571. Hui, X.; Zhang, L.; Cao, L.; Huang, K.; Zhao, Y.; Zhang, Y.; Chen, X.; Lin, X.; Chen, M.; Jin, M. SARS-CoV-2 promote autophagy to suppress type I interferon response. Signal. Transduct. Target 2021, 6, 180. [CrossRef]

572. Yuen, C.K.; Lam, J.Y.; Wong, W.M.; Mak, L.F.; Wang, X.; Chu, H.; Cai, J.P.; Jin, D.Y.; To, K.K.; Chan, J.F.; et al. SARS-CoV-2 nsp13, nsp14, nsp15 and orf6 function as potent interferon antagonists. Emerg. Microbes Infect. 2020, 9, 1418-1428. [CrossRef]

573. Xia, H.; Cao, Z.; Xie, X.; Zhang, X.; Chen, J.Y.; Wang, H.; Menachery, V.D.; Rajsbaum, R.; Shi, P.Y. Evasion of Type I Interferon by SARS-CoV-2. Cell Rep. 2020, 33, 108234. [CrossRef]

574. Zhang, Q.; Bastard, P.; Liu, Z.; Le Pen, J.; Moncada-Velez, M.; Chen, J.; Ogishi, M.; Sabli, I.K.D.; Hodeib, S.; Korol, C.; et al. Inborn errors of type I IFN immunity in patients with life-threatening COVID-19. Science 2020, 370. [CrossRef]

575. Bastard, P.; Rosen, L.B.; Zhang, Q.; Michailidis, E.; Hoffmann, H.H.; Zhang, Y.; Dorgham, K.; Philippot, Q.; Rosain, J.; Beziat, V.; et al. Autoantibodies against type I IFNs in patients with life-threatening COVID-19. Science 2020, 370. [CrossRef]

576. Stertz, S.; Hale, B.G. Interferon system deficiencies exacerbating severe pandemic virus infections. Trends Microbiol. 2021. [CrossRef] [PubMed]

577. Bastard, P.; Orlova, E.; Sozaeva, L.; Levy, R.; James, A.; Schmitt, M.M.; Ochoa, S.; Kareva, M.; Rodina, Y.; Gervais, A.; et al. Preexisting autoantibodies to type I IFNs underlie critical COVID-19 pneumonia in patients with APS-1. J. Exp. Med. 2021, 218. [CrossRef] [PubMed]

578. Wang, E.Y.; Mao, T.; Klein, J.; Dai, Y.; Huck, J.D.; Jaycox, J.R.; Liu, F.; Zhou, T.; Israelow, B.; Wong, P.; et al. Diverse Functional Autoantibodies in Patients with COVID-19. Nature 2021. [CrossRef] [PubMed]

579. Letko, M.; Marzi, A.; Munster, V. Functional assessment of cell entry and receptor usage for SARS-CoV-2 and other lineage B betacoronaviruses. Nat. Microbiol. 2020, 5, 562-569. [CrossRef] [PubMed]

580. Haga, S.; Yamamoto, N.; Nakai-Murakami, C.; Osawa, Y.; Tokunaga, K.; Sata, T.; Yamamoto, N.; Sasazuki, T.; Ishizaka, Y. Modulation of TNF-alpha-converting enzyme by the spike protein of SARS-CoV and ACE2 induces TNF-alpha production and facilitates viral entry. Proc. Natl. Acad. Sci. USA 2008, 105, 7809-7814. [CrossRef]

581. Smith, J.C.; Sausville, E.L.; Girish, V.; Yuan, M.L.; Vasudevan, A.; John, K.M.; Sheltzer, J.M. Cigarette Smoke Exposure and Inflammatory Signaling Increase the Expression of the SARS-CoV-2 Receptor ACE2 in the Respiratory Tract. Dev. Cell 2020, 53, 514-529.e3. [CrossRef] [PubMed]

582. Bunyavanich, S.; Do, A.; Vicencio, A. Nasal Gene Expression of Angiotensin-Converting Enzyme 2 in Children and Adults. JAMA 2020, 323, 2427-2429. [CrossRef]

583. Trouillet-Assant, S.; Viel, S.; Gaymard, A.; Pons, S.; Richard, J.C.; Perret, M.; Villard, M.; Brengel-Pesce, K.; Lina, B.; Mezidi, M.; et al. Type I IFN immunoprofiling in COVID-19 patients. J. Allergy Clin. Immunol. 2020, 146, 206-208.e2. [CrossRef] [PubMed]

584. Herbeuval, J.P.; Shearer, G.M. HIV-1 Immunopathogenesis: How Good Interferon Turns Bad. Clin. Immunol. 2007, 123, 121-128. [CrossRef] 
585. Azzoni, L.; Foulkes, A.S.; Papasavvas, E.; Mexas, A.M.; Lynn, K.M.; Mounzer, K.; Tebas, P.; Jacobson, J.M.; Frank, I.; Busch, M.P.; et al. Pegylated Interferon Alfa-2a Monotherapy Results in Suppression of HIV Type 1 Replication and Decreased Cell-Associated HIV DNA Integration. J. Infect. Dis. 2013, 207, 213-222. [CrossRef] [PubMed]

586. Clifford Lane, H.; Feinberg, J.; Davey, V.; Deyton, L.; Baseler, M.; Manischewitz, J.; Masur, H.; Kovacs, J.A.; Herpin, B.; Walker, R.; et al. Anti-Retroviral Effects Of Interferon-A In Aids-Associated Kaposi's Sarcoma. Lancet 1988, 332, 1218-1222. [CrossRef]

587. Manion, M.; Rodriguez, B.; Medvik, K.; Hardy, G.; Harding, C.V.; Schooley, R.T.; Pollard, R.; Asmuth, D.; Murphy, R.; Barker, E.; et al. Interferon-Alpha Administration Enhances CD8+ T Cell Activation in HIV Infection. PLoS ONE 2012, 7, e30306. [CrossRef]

588. Sandler, N.G.; Bosinger, S.E.; Estes, J.D.; Zhu, R.T.R.; Tharp, G.K.; Boritz, E.; Levin, D.; Wijeyesinghe, S.; Makamdop, K.N.; Del Prete, G.Q.; et al. Type i interferon responses in rhesus macaques prevent SIV infection and slow disease progression. Nature 2014, 511, 601-605. [CrossRef]

589. Rotger, M.; Dalmau, J.; Rauch, A.; McLaren, P.; Bosinger, S.E.; Martinez, R.; Sandler, N.G.; Roque, A.; Liebner, J.; Battegay, M.; et al. Comparative transcriptomics of extreme phenotypes of human HIV-1 infection and SIV infection in sooty mangabey and rhesus macaque. J. Clin. Invest. 2011, 121, 2391-2400. [CrossRef]

590. Rotger, M.; Dang, K.K.; Fellay, J.; Heinzen, E.L.; Feng, S.; Descombes, P.; Shianna, K.V.; Ge, D.; Günthard, H.F.; Goldstein, D.B.; et al. Genome-Wide mRNA Expression Correlates of Viral Control in CD4+ T-Cells from HIV-1-Infected Individuals. PLoS Pathog. 2010, 6, e1000781. [CrossRef] [PubMed]

591. Deyton, L.R.; Walker, R.E.; Kovacs, J.A.; Herpin, B.; Parker, M.; Masur, H.; Fauci, A.S.; Lane, H.C. Reversible Cardiac Dysfunction Associated with Interferon Alfa Therapy in AIDS Patients with Kaposi's Sarcoma. N. Engl. J. Med. 1989, 321, 1246-1249. [CrossRef] [PubMed]

592. Vakharia, D.D.; Szebenyi, S.E.; Gutterman, J.U.; Rich, S.A. Interferon- $\alpha$-Induced Human Lupus Inclusions and p36 Protein in Cancer and AIDS. J. Interferon Cytokine Res. 1996, 16, 709-715. [CrossRef] [PubMed]

593. Cheng, L.; Ma, J.; Li, J.; Li, D.; Li, G.; Li, F.; Zhang, Q.; Yu, H.; Yasui, F.; Ye, C.; et al. Blocking type I interferon signaling enhances T cell recovery and reduces HIV-1 reservoirs. J. Clin. Invest. 2017, 127, 269-279. [CrossRef]

594. Su, L. Pathogenic Role of Type I Interferons in HIV-Induced Immune Impairments in Humanized Mice. Curr. Med. Group LLC 1 2019, 16, 224-229. [CrossRef]

595. Abrahams, M.R.; Anderson, J.A.; Giorgi, E.E.; Seoighe, C.; Mlisana, K.; Ping, L.H.; Athreya, G.S.; Treurnicht, F.K.; Keele, B.F.; Wood, N.; et al. Quantitating the Multiplicity of Infection with Human Immunodeficiency Virus Type 1 Subtype C Reveals a Non-Poisson Distribution of Transmitted Variants. J. Virol. 2009, 83, 3556-3567. [CrossRef]

596. Keele, B.F.; Giorgi, E.E.; Salazar-Gonzalez, J.F.; Decker, J.M.; Pham, K.T.; Salazar, M.G.; Sun, C.; Grayson, T.; Wang, S.; Li, H.; et al Identification and characterization of transmitted and early founder virus envelopes in primary HIV-1 infection. Proc. Natl. Acad. Sci. USA 2008, 105, 7552-7557. [CrossRef]

597. Salazar-Gonzalez, J.F.; Salazar, M.G.; Keele, B.F.; Learn, G.H.; Giorgi, E.E.; Li, H.; Decker, J.M.; Wang, S.; Baalwa, J.; Kraus, M.H.; et al. Genetic identity, biological phenotype, and evolutionary pathways of transmitted/founder viruses in acute and early HIV-1 infection. J. Exp. Med. 2009, 206, 1273-1289. [CrossRef]

598. Patel, V.V.; Felsen, U.R.; Fisher, M.; Fazzari, M.J.; Ginsberg, M.S.; Beil, R.; Akiyama, M.J.; Anastos, K.; Hanna, D.B. Clinical Outcomes and Inflammatory Markers by HIV Serostatus and Viral Suppression in a Large Cohort of Patients Hospitalized With COVID-19. J. Acquir. Immune Defic. Syndr. 2021, 86, 224-230. [CrossRef]

599. Sachdev, D.; Mara, E.; Hsu, L.; Scheer, S.; Rutherford, G.; Enanoria, W.; Gandhi, M. COVID-19 Susceptibility and Outcomes Among People Living With HIV in San Francisco. J. Acquir. Immune Defic. Syndr. 2021, 86, 19-21. [CrossRef]

600. Suwanwongse, K.; Shabarek, N. Variation in mortality of HIV/SARS-CoV-2 coinfected patients in the Bronx, New York City. J. Med. Virol. 2021, 93, 603-605. [CrossRef]

601. Fung, M.; Babik, J.M. COVID-19 in Immunocompromised Hosts: What We Know So Far. Clin. Infect. Dis. 2021, 72, 340-350. [CrossRef]

602. Ho, H.E.; Mathew, S.; Peluso, M.J.; Cunningham-Rundles, C. Clinical outcomes and features of COVID-19 in patients with primary immunodeficiencies in New York City. J. Allergy Clin. Immunol. Pract. 2021, 9, 490-493.e2. [CrossRef]

603. Etienne, N.; Karmochkine, M.; Slama, L.; Pavie, J.; Batisse, D.; Usubillaga, R.; Letembet, V.A.; Brazil-Le, P.; Canoui, E.; Slama, D.; et al. HIV infection and COVID-19: Risk factors for severe disease. Aids 2020, 34, 1771-1774. [CrossRef] [PubMed]

604. Hoffmann, C.; Casado, J.L.; Härter, G.; Vizcarra, P.; Moreno, A.; Cattaneo, D.; Meraviglia, P.; Spinner, C.D.; Schabaz, F.; Grunwald, S.; et al. Immune deficiency is a risk factor for severe COVID-19 in people living with HIV. HIV Med. 2020. [CrossRef]

605. Tesoriero, J.M.; Swain, C.E.; Pierce, J.L.; Zamboni, L.; Wu, M.; Holtgrave, D.R.; Gonzalez, C.J.; Udo, T.; Morne, J.E.; Hart-Malloy, R.; et al. COVID-19 Outcomes Among Persons Living With or Without Diagnosed HIV Infection in New York State. JAMA Netw. Open 2021, 4, e2037069. [CrossRef]

606. Charre, C.; Icard, V.; Pradat, P.; Brochier, C.; Lina, B.; Chidiac, C.; Cotte, L. Coronavirus disease 2019 attack rate in HIV-infected patients and in preexposure prophylaxis users. AIDS 2020, 34, 1765-1770. [CrossRef] [PubMed]

607. Cooper, T.J.; Woodward, B.L.; Alom, S.; Harky, A. Coronavirus disease 2019 (COVID-19) outcomes in HIV / AIDS patients: A systematic review. HIV Med. 2020, 21, 567-577. [CrossRef] [PubMed]

608. Del Amo, J.; Polo, R.; Moreno, S.; Diaz, A.; Martinez, E.; Arribas, J.R.; Jarrin, I.; Hernan, M.A.; The Spanish, H.I.V.C.-C. Incidence and Severity of COVID-19 in HIV-Positive Persons Receiving Antiretroviral Therapy: A Cohort Study. Ann. Intern. Med. 2020, 173, 536-541. [CrossRef] 
609. Mahdi, M.; Mótyán, J.A.; Szojka, Z.I.; Golda, M.; Miczi, M.; Tőzsér, J. Analysis of the efficacy of HIV protease inhibitors against SARS-CoV-2's main protease. Virol. J. 2020, 17, 190. [CrossRef]

610. Singh, T.U.; Parida, S.; Lingaraju, M.C.; Kesavan, M.; Kumar, D.; Singh, R.K. Drug repurposing approach to fight COVID-19. Pharm. Rep. 2020, 72, 1479-1508. [CrossRef] [PubMed]

611. Mohamed, K.; Yazdanpanah, N.; Saghazadeh, A.; Rezaei, N. Computational drug discovery and repurposing for the treatment of COVID-19: A systematic review. Bioorg. Chem. 2021, 106, 104490. [CrossRef] [PubMed]

612. Cao, B.; Wang, Y.; Wen, D.; Liu, W.; Wang, J.; Fan, G.; Ruan, L.; Song, B.; Cai, Y.; Wei, M.; et al. A Trial of Lopinavir-Ritonavir in Adults Hospitalized with Severe Covid-19. N. Engl. J. Med. 2020, 382, 1787-1799. [CrossRef] [PubMed]

613. Saleemi, M.A.; Ahmad, B.; Benchoula, K.; Vohra, M.S.; Mea, H.J.; Chong, P.P.; Palanisamy, N.K.; Wong, E.H. Emergence and molecular mechanisms of SARS-CoV-2 and HIV to target host cells and potential therapeutics. Infect. Genet. Evol. J. Mol. Epidemiol. Evol. Genet. Infect. Dis. 2020, 85, 104583. [CrossRef]

614. Calza, L.; Bon, I.; Borderi, M.; Colangeli, V.; Borioni, A.; Re, M.C.; Viale, P. COVID-19 Outcomes in Patients With Uncontrolled HIV-1 Infection. J. Acquir. Immune Defic. Syndr. 2021, 86, e15-e17. [CrossRef]

615. Karim, F.; Gazy, I.; Cele, S.; Zungu, Y.; Krause, R.; Bernstein, M.; Ganga, Y.; Rodel, H.; Mthabela, N.; Mazibuko, M.; et al. HIV infection alters SARS-CoV-2 responsive immune parameters but not clinical outcomes in COVID-19 disease. medRxiv 2020. [CrossRef]

616. Braunstein, S.L.; Lazar, R.; Wahnich, A.; Daskalakis, D.C.; Blackstock, O.J. COVID-19 infection among people with HIV in New York City: A population-level analysis of linked surveillance data. Clin. Infect. Dis. 2020. [CrossRef]

617. Childs, K.; Post, F.A.; Norcross, C.; Ottaway, Z.; Hamlyn, E.; Quinn, K.; Juniper, T.; Taylor, C. Hospitalized Patients With COVID-19 and Human Immunodeficiency Virus: A Case Series. Clin. Infect. Dis. 2020, 71, 2021-2022. [CrossRef]

618. Geretti, A.M.; Stockdale, A.J.; Kelly, S.H.; Cevik, M.; Collins, S.; Waters, L.; Villa, G.; Docherty, A.; Harrison, E.M.; Turtle, L.; et al. Outcomes of COVID-19 related hospitalization among people with HIV in the ISARIC WHO Clinical Characterization Protocol (UK): A prospective observational study. Clin. Infect. Dis. 2020. [CrossRef] [PubMed]

619. Bhaskaran, K.; Rentsch, C.T.; MacKenna, B.; Schultze, A.; Mehrkar, A.; Bates, C.J.; Eggo, R.M.; Morton, C.E.; Bacon, S.C.J.; Inglesby, P.; et al. HIV infection and COVID-19 death: A population-based cohort analysis of UK primary care data and linked national death registrations within the OpenSAFELY platform. Lancet HIV 2021, 8, e24-e32. [CrossRef]

620. Riou, C.; Du Bruyn, E.; Stek, C.; Daroowala, R.; Goliath, R.T.; Abrahams, F.; Said-Hartley, Q.; Allwood, B.W.; Hsiao, N.Y.; Wilkinson, K.A.; et al. Relationship of SARS-CoV-2-specific CD4 response to COVID-19 severity and impact of HIV-1 and Tuberculosis co-infection. J. Clin. Invest. 2021. [CrossRef]

621. Dandachi, D.; Geiger, G.; Montgomery, M.W.; Karmen-Tuohy, S.; Golzy, M.; Antar, A.A.R.; Llibre, J.M.; Camazine, M.; Diaz-De Santiago, A.; Carlucci, P.M.; et al. Characteristics, Comorbidities, and Outcomes in a Multicenter Registry of Patients with HIV and Coronavirus Disease-19. Clin. Infect. Dis. 2020. [CrossRef]

622. Huang, J.; Xie, N.; Hu, X.; Yan, H.; Ding, J.; Liu, P.; Ma, H.; Ruan, L.; Li, G.; He, N.; et al. Epidemiological, virological and serological features of COVID-19 cases in people living with HIV in Wuhan City: A population-based cohort study. Clin. Infect. Dis. 2020. [CrossRef]

623. Spinelli, M.A.; Lynch, K.L.; Yun, C.; Glidden, D.V.; Peluso, M.J.; Henrich, T.J.; Gandhi, M.; Brown, L.B. SARS-CoV-2 seroprevalence, and IgG concentration and pseudovirus neutralising antibody titres after infection, compared by HIV status: A matched casecontrol observational study. Lancet HIV 2021. [CrossRef]

624. Shinde, V.; Bhikha, S.; Hoosain, Z.; Archary, M.; Bhorat, Q.; Fairlie, L.; Lalloo, U.; Masilela, M.S.L.; Moodley, D.; Hanley, S.; et al. Efficacy of NVX-CoV2373 Covid-19 Vaccine against the B.1.351 Variant. N. Engl. J. Med. 2021, 384, 1899-1909. [CrossRef]

625. Hogan, A.B.; Jewell, B.L.; Sherrard-Smith, E.; Vesga, J.F.; Watson, O.J.; Whittaker, C.; Hamlet, A.; Smith, J.A.; Winskill, P.; Verity, R.; et al. Potential impact of the COVID-19 pandemic on HIV, tuberculosis, and malaria in low-income and middle-income countries: A modelling study. Lancet Glob. Health 2020, 8, e1132-e1141. [CrossRef]

626. Hu, R.; Yan, H.; Liu, M.; Tang, L.; Kong, W.; Zhu, Z.; Liu, P.; Bai, W.; Hu, X.; Ding, J.; et al. Brief Report: Virologic and Immunologic Outcomes for HIV Patients With Coronavirus Disease 2019. J. Acquir. Immune Defic. Syndr. 2021, 86, 213-218. [CrossRef] [PubMed]

627. Mellor, M.M.; Bast, A.C.; Jones, N.R.; Roberts, N.W.; Ordonez-Mena, J.M.; Reith, A.J.M.; Butler, C.C.; Matthews, P.C.; Dorward, J. Risk of adverse coronavirus disease 2019 outcomes for people living with HIV. AIDS 2021, 35, F1-F10. [CrossRef] [PubMed] 